\title{
Evaluating the Effects of Tri-Butyl Phosphate and Normal Paraffin Hydrocarbon in Simulated Low-Activity Waste Solution on Ultrafiltration
}

by

J. R. Zamecnik

Westinghouse Savannah River Company

Savannah River Site

Aiken, South Carolina 29808

M. A. Baich

This paper was prepared in connection with work done under the above contract number with the $U$. S. Department of Energy. By acceptance of this paper, the publisher and/or recipient acknowledges the U. S. Government's right to retain a nonexclusive, royalty-free license in and to any copyright covering this paper, along with the right to reproduce and to authorize others to reproduce all or part of the copyrighted paper. 
This document was prepared in conjunction with work accomplished under Contract No. DE-AC09-96SR18500 with the U. S. Department of Energy.

\section{DISCLAIMER}

This report was prepared as an account of work sponsored by an agency of the United States Government. Neither the United States Government nor any agency thereof, nor any of their employees, makes any warranty, express or implied, or assumes any legal liability or responsibility for the accuracy, completeness, or usefulness of any information, apparatus, product or process disclosed, or represents that its use would not infringe privately owned rights. Reference herein to any specific commercial product, process or service by trade name, trademark, manufacturer, or otherwise does not necessarily constitute or imply its endorsement, recommendation, or favoring by the United States Government or any agency thereof. The views and opinions of authors expressed herein do not necessarily state or reflect those of the United States Government or any agency thereof.

This report has been reproduced directly from the best available copy.

Available for sale to the public, in paper, from: U.S. Department of Commerce, National Technical Information Service, 5285 Port Royal Road, Springfield, VA 22161, phone: (800) 553-6847, fax: (703) 605-6900

email: orders@ntis.fedworld.gov

online ordering: http://www.ntis.gov/help/index.asp

Available electronically at http://www.osti.gov/bridge

Available for a processing fee to U.S. Department of Energy and its contractors, in paper, from: U.S. Department of Energy, Office of Scientific and Technical Information, P.O. Box 62, Oak Ridge, TN 37831-0062,

phone: (865)576-8401,

fax: (865)576-5728

email: $\underline{\text { reports@ adonis.osti.gov }}$ 
Evaluating The Effects Of Tri-Butyl Phosphate And Normal Paraffin Hydrocarbon In Simulated Low-Activity Waste Solution On Ultrafiltration

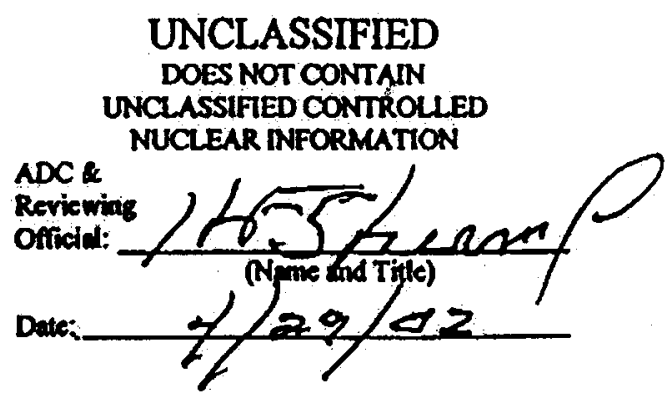

Westinghouse Savannah River Company Savannah River Site

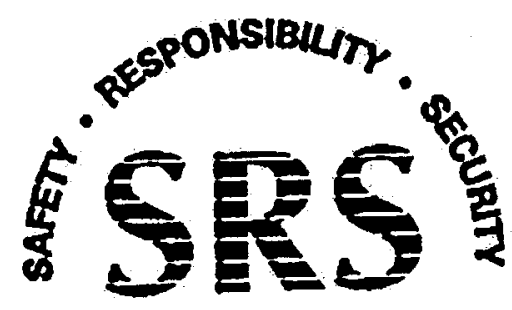
Aiken, SC 29808 
WSRC-TR-2002-00108, Rev. 0

SRT-RPP-2002-00041, Rev. 0

KEYWORDS:

Hanford River Protection Project

Crossflow Filtration

Tank 241-AZ-101

Envelope B, Envelope D

Separable Organics

\section{Evaluating The Effects Of Tri-Butyl Phosphate And Normal Paraffin Hydrocarbon In Simulated Low-Activity Waste Solution On Ultrafiltration}

SAVANNAH RIVER TECHNOLOGY CENTER

J. R. Zamecnik

M. A. Baich

April 25, 2002

Westinghouse Savannah River Company

Savannah River Site

Aiken, SC 29808

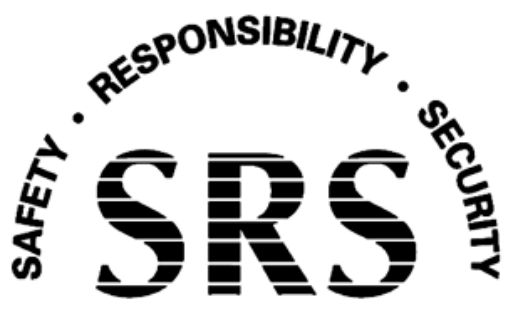

Prepared for the U.S. Department of Energy under Contract No. DE-AC09-96SR18500 
DOCOMDAT: WSRCAR-2002+00108,Rev.0 (SRT-RPP-202-0004, Rev.0)

TITL:

Bvaluathe The Eutects Of Tri-Butyl Phosphnte Abd Normel Farminn Bydrocorbon in Stmulated Low-Activity Wate Solution On Uitranitrotion

APPROVAUS

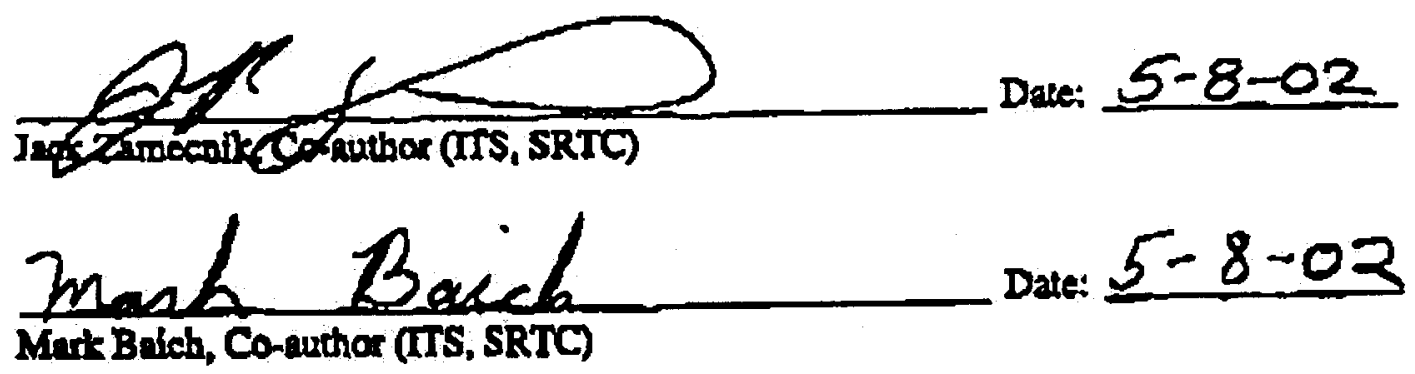

Paul Bunket Date: $5 / 8 / 02$ Pavl Burket, Tecbnical Reviower (ITS, SRTC)

Jringlpinsice

Dare: $5 / 8 / 02$

Michnel Poirier, Pribelpal Investigalor (WPT, SRTC)

$5 / 8 / 02$

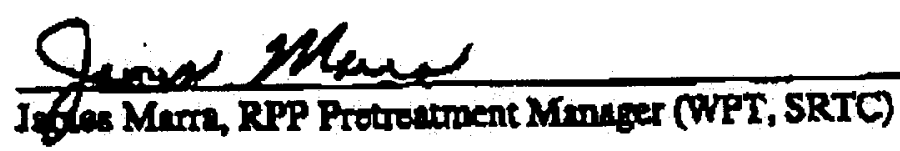

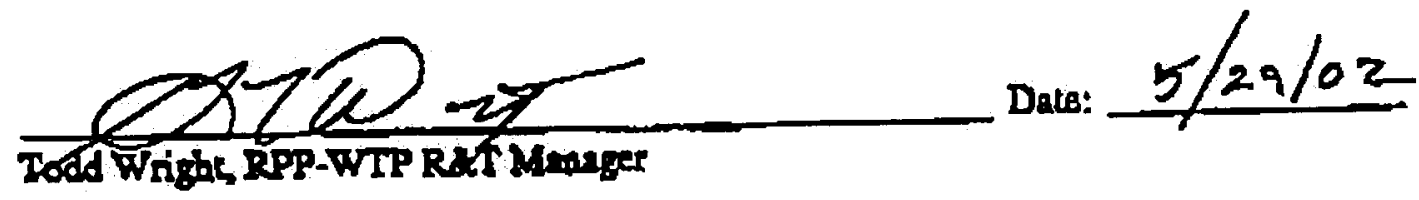

Pago it 


\section{Table of Contents}

1.0 Executive Summary.................................................................................................................. 1

2.0 Background and Introduction ........................................................................................ 1

2.1 Objectives.................................................................................................................................................... 1

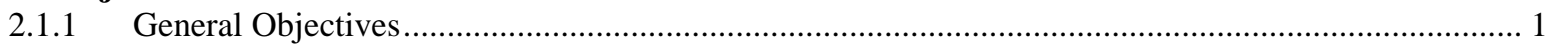

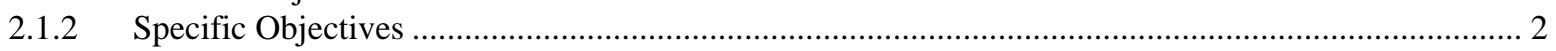

2.2 Experimental System \& Operation............................................................................................... 2

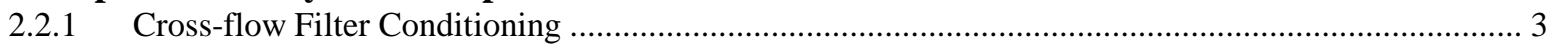

2.3 Experimental Methods \& Materials ................................................................................................ 4

2.4 Experimental Runs Matrix.................................................................................................................

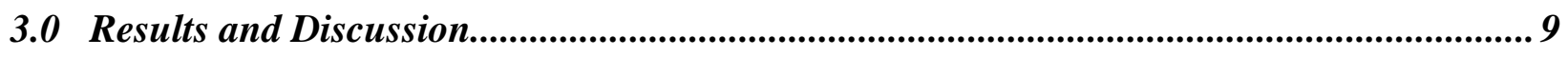

3.1 Experimental Data............................................................................................................................ 9

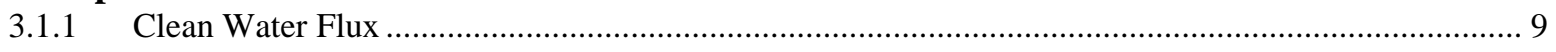

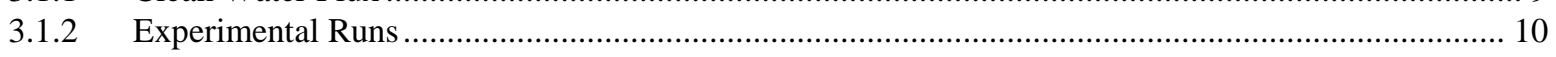

3.2 Simulant and Permeate Composition Versus Time ...................................................................... 12

3.3 Organics in Slurry and Permeate ................................................................................................. 22

3.4 Statistical Analysis of Data ................................................................................................. 24

3.5 Quality Assurance …............................................................................................................ 27

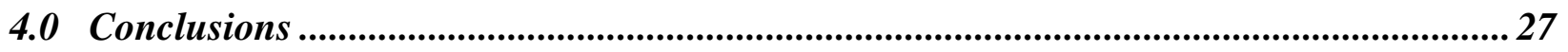

5.0 Appendices.........................................................................................................................29

5.1 Appendix - Supernate Recipe ...................................................................................... 29

5.2 Appendix - Simulant Compositions …………………................................................................ 30

5.3 Appendix - Experimental Design............................................................................................. 40

5.4 Appendix - Experimental Results......................................................................................... 42

5.5 Appendix - Curve Fits from JMP.................................................................................................... 66

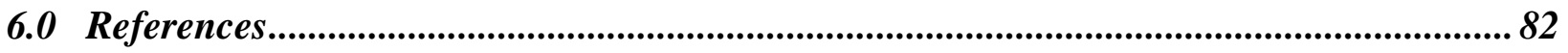




\section{List of Tables}

Table 2.1 Amounts of Simulants and Chemicals Used ..................................................................5

Table 2.2 Measured Initial Composition of Simulant from Supernate, Solids, \& Trim Chemicals ................................................................................................................... 6

Table 3.1 Average Compositions of Slurry, Permeate, and Solids ........................................ 15

Table 3.2 Composition of Permeate....................................................................................... 20

Table 3.3 Dibutylphosphate and 1-Butanol in Samples ............................................................. 24

Table 3.4 Parameter Estimates for Model with Velocity, Adjusted Time, Pressure, and Organics Content ................................................................................................ 25

Table 3.5 Parameter Estimates for Model with Velocity and Adjusted Time....................... 25

Table 5.1 Supernate Simulant Samples............................................................................................ 30

Table 5.2 Sludge Solids Sample \#1: Composition of solids filtered from sample. .............. 32

Table 5.3 Sludge Solids Sample \#2: Composition of solids filtered from sample. .............. 33

Table 5.4 Sludge Solids Sample \#3: Composition of solids filtered from sample. ............... 34

Table 5.5 Sludge Sample \#1: Composition of filtrate from sample.........................................35

Table 5.6 Sludge Sample \#2: Composition of filtrate from sample.......................................... 36

Table 5.7 Sludge Sample \#3: Composition of filtrate calculated from composition of Sample \#2 by ratio. ..................................................................................................... 37

Table 5.8 Overall Compositions of Samples \#1-3 Calculated from Solids and Filtrate Analyses....................................................................................................................... 38

Table 5.9 Trim Chemicals Added ....................................................................................................... 39

Table 5.10 Experimental Design Table .................................................................................................... 40 


\section{List of Figures}

Figure 2.1 Crossflow Ultrafilter System .................................................................................................... 3

Figure 2.2 Cross-flow Filtration Schematic ...................................................................................... 4

Figure 2.3 Level Z (No Organics) Factorial Design........................................................................... 8

Figure 2.4 Level L (25 mg/L Each TBP \& NPH) Factorial Design ........................................... 8

Figure 2.5 Level H (2500 mg/L Each TBP \& NPH) Factorial Design ....................................... 9

Figure 3.1 Clean Water Flux Prior to Experimentation ................................................................. 10

Figure 3.2 Factorial Data Points for All Levels ............................................................................... 11

Figure 3.3 All Centroid Flux Data ........................................................................................... 12

Figure 3.4 Total Solids, Suspended Solids, and Specific Gravity versus Run ....................... 13

Figure 3.5 Total Solids, Suspended Solids, and Specific Gravity versus Level .................... 16

Figure 3.6 Ion Chromatography Data for Slurry Samples............................................................ 16

Figure 3.7 Ion Chromatography Data for Permeate .................................................................... 17

Figure 3.8 Slurry Carbon and Free Hydroxide Analyses ............................................................. 17

Figure 3.9 IC, Hydroxide, and TIC/TOC mg/L Data Normalized to Constant Average Nitrate.............................................................................................................. 18

Figure 3.10 IC, Hydroxide, and TIC/TOC Molar Data Normalized to Constant Average Nitrate................................................................................................................ 18

Figure 3.11 Elemental Analyses (by ICPES) for Major Metals .................................................... 19

Figure 3.12 Ratio of Iron and Zirconium to Suspended Solids................................................... 19

Figure 3.13 Photos of Slurry Samples...................................................................................................... 22

Figure 3.14 Possible Organic Phase Separation in Piping ................................................................ 22

Figure 3.15 Organics Concentrations in Slurry and Permeate ...................................................... 23

Figure 3.16 Fitted Data for Flux versus Velocity and Time ........................................................... 26

Figure 3.17 Fitted Data for Flux versus Velocity, Time, and Organics........................................ 27 


\section{List of Acronyms}

$\begin{array}{ll}\text { ADS } & \text { Analytical Development Section } \\ \text { DI } & \text { deionized } \\ \text { DBP } & \text { dibutylphosphate } \\ \text { fps } & \text { feet per second } \\ \text { HLW } & \text { high level waste } \\ \text { IC } & \text { ion chromatography } \\ \text { ICPES } & \text { inductively coupled plasma emission spectroscopy } \\ \text { ITS } & \text { Immobilization Technology Section } \\ \text { NPH } & \text { normal paraffin hydrocarbon (dodecane) } \\ \text { QA } & \text { Quality Assurance } \\ \text { QC } & \text { Quality Control } \\ \text { SpGr } & \text { specific gravity } \\ \text { SRS } & \text { Savannah River Site } \\ \text { SRTC } & \text { Savannah River Technology Center } \\ \text { TBP } & \text { tributyl phosphate } \\ \text { TC } & \text { total carbon } \\ \text { TIC } & \text { total inorganic carbon } \\ \text { TOC } & \text { total organic carbon } \\ \text { TS } & \text { total solids } \\ \text { TSS } & \text { total suspended solids } \\ \text { WPT } & \text { Waste Processing Technology (Section) } \\ \text { WSRC } & \text { Westinghouse Savannah River Company } \\ \end{array}$




\subsection{Executive Summary}

The effect on the filter flux of tributyl phosphate (TBP) and normal paraffin hydrocarbon (dodecane) in a simulated AZ-101 $3.5 \mathrm{wt} \%$ insoluble, 28-30 wt\% total solids slurry was studied. A $0.1 \mu \mathrm{m}$ sintered metal Mott filter element was used for this work. The operating parameters used were specified by the customer to be within the range applicable to the full-scale plant. Specifically, transmembrane pressures of 20-60 psi and linear velocities of 7-15 fps were tested.

With TBP and dodecane at up to $2500 \mathrm{mg} / \mathrm{L}$ each, no effect on the filter flux was found. Therefore, the de minimis concentration of separable organics, if one exists, must be greater than $2500 \mathrm{mg} / \mathrm{L}$.

All measured fluxes exceeded the customer's minimum of $0.014 \mathrm{gpm} / \mathrm{ft}^{2}$. Simulants with no organics, $25 \mathrm{mg} / \mathrm{L}$ each, and $2500 \mathrm{mg} / \mathrm{L}$ each were concentrated by a factor of one to produce permeate for ion exchange tests.

Cleaning of the system after use with the organics proved difficult using only water and nitric acid. It should be noted that the concentrations of separable organics were much higher than should actually be seen in the WTP. We recommend that the effect of TBP and NPH be studied further during filter cleaning tests.

\subsection{Background and Introduction}

Detailed background on the origin of this task is given in the customer's (RPP-WTP) specifying document: TSP-W375-00-00036, Rev. 1. ${ }^{1}$ This work is specified in the RPP-WTP R/T Plan (PL-W375-TE00007, Rev. 0).

\subsection{Objectives}

\subsubsection{General Objectives}

The effects of trace quantities of separable organics (tri-butyl phosphate $\{\mathrm{TBP}\}$ and normal paraffin hydrocarbon $\{\mathrm{NPH}\}$, herein also called "organics") in the tank waste liquid feed to the Hanford River Protection Project Waste Treatment Plant (RPP-WTP) and the fate of the separable organics within the system shall be evaluated. Bulk average concentrations of $\sim 25 \mathrm{ppm}$ (or $\mathrm{mg} / \mathrm{L}$ ) are expected, but instantaneous concentrations could be higher. Each potentially affected unit operation, including ultrafiltration, ion exchange, and evaporation shall be examined for process, safety, and permitting implications. Based upon the results of these tests, the SRTC shall propose a de minimis concentration level for separable organics that could be sent to the WTP without adversely affecting the WTP. Specifically, the effects of insoluble TBP and NPH on ultrafiltration filter flux rate with a simulated AZ-101 solution are to be evaluated in this task. 
The products from these filtration tests will be used as the feed for cesium and technetium ion exchange studies, which will be covered by a separate Task Technical \& Quality Assurance Plan. Evaporation studies are described in a separate customer request. ${ }^{2}$

\subsubsection{Specific Objectives}

1. Determine the effect on filter flux rate, for a $0.1 \mu \mathrm{m}$ sintered metal Mott filter element, of processing a simulated waste solution containing approximately $25 \mathrm{ppm}$ (mg/L) TBP and 25 ppm NPH each above their solubility limit. The solubility limit for TBP is approximately $1.1 \mathrm{mg} / \mathrm{L}$. Although the solubility limit for NPH in the salt solution is not exactly known, it should be much less than that for TBP since NPH is more non-polar.

2. Determine the effect on filter flux rate, for a $0.1 \mu \mathrm{m}$ sintered metal Mott filter element, of processing a simulated waste solution containing incrementally higher levels of TBP and NPH each above their solubility limit. Organic levels up to $2500 \mathrm{mg} / \mathrm{L}$ each are to be studied.

3. For the simulant without TBP/NPH and simulant with two levels of TBP and NPH, produce at least 2.0-2.5 liters of permeate solution of each for use in ion exchange tests.

\subsection{Experimental System \& Operation}

Figure 2.1 shows a photograph of the system. A schematic of the experimental system is shown in Figure 2.2. The experimental crossflow filter, or Cold Cells Unit Filter (CUF) contains a single crossflow filter tube. A 5-stage centrifugal pump is used to feed the slurry into the filter. Some liquid permeates through the filter wall (permeate) and the remainder passes through the filter axially (concentrate). As solids accumulate on the filter wall, backpulsing can be used to remove accumulation. The filter in this work was a 3/8-inch internal diameter, 2-foot long Mott Metallurgical sintered stainless steel filter. The nominal pore size was $0.1 \mu \mathrm{m}$. The single filter tube was mounted horizontally in a stainless steel housing of welded construction.

Filtrate flowrate was measured with a graduated collection glass and stopwatch. The simple backpulse system is manually operated. The backpulse chamber is first charged with filtrate followed by compressed air. Quickly opening a toggle valve below the chamber forces reverse flow of filtrate upon the filter medium. Standard Bourdon tube type pressure gauges on both the inlet and exit of the filter indicate pressure. A thermocouple mounted near the bottom of the reservoir measures slurry temperature directly. A heat exchanger and chiller unit provide temperature control. All experiments were performed at $25 \pm 5^{\circ} \mathrm{C}$.

Slurry is recirculated through a heat exchanger and the filter element. A magnetic flow meter measures the volumetric flow in the system, which is displayed on a digital read out along with the feed vessel temperature. The filter is back-pulsed before the start each experiment by 
pressurizing the backpulse tank to $45 \mathrm{psig}$. The toggle valve is then open repeatedly at no flow conditions. When air is observed returning to the feed vessel, back-pulsing is stopped. Each set of experimental conditions are set by adjusting the flow of air to the feed pump and adjusting the slurry flow control valve until the desired flow and transmembrane pressures are achieved. The system was operated per an approved operating procedure. ${ }^{3}$

\subsubsection{Cross-flow Filter Conditioning}

The equipment internals were first rinsed with flush solutions or DI water per the steps below. The filter cleaning fluids were pre-filtered with $0.22 \mu \mathrm{m}$ nylon filters before use. The laboratory de-ionizing unit uses a $0.22 \mu \mathrm{m}$ filter on the discharge.

A previously used filter element was used. It was first drained of any previous fluid, then filled with deionized water. This water was filtered through a $0.22 \mu \mathrm{m}$ nylon filter, which was located on the deionizer. This water was then recirculated through the filter concentrate side for at least 15 minutes. The filtrate generated was recycled back to the feed tank. The system was then drained, filled with $\sim 1 \mathrm{M}$ nitric acid, and recirculated for at least one hour. The filtrate generated was again recycled back to the reservoir. At least 2 backpulses were done in this period to clean the backpulse system as well as the filter. The system was then drained and the backpulse chamber is purged to empty it. A solution of $0.01 \mathrm{M} \mathrm{NaOH}$ was then added and recirculated for at least 15 minutes. At least 2 backpulses were done in this period to clean the backpulse system as well as the filter. The entire system and backpulse chamber were then drained and then refilled with fresh DI water (the system is laid up with DI water).

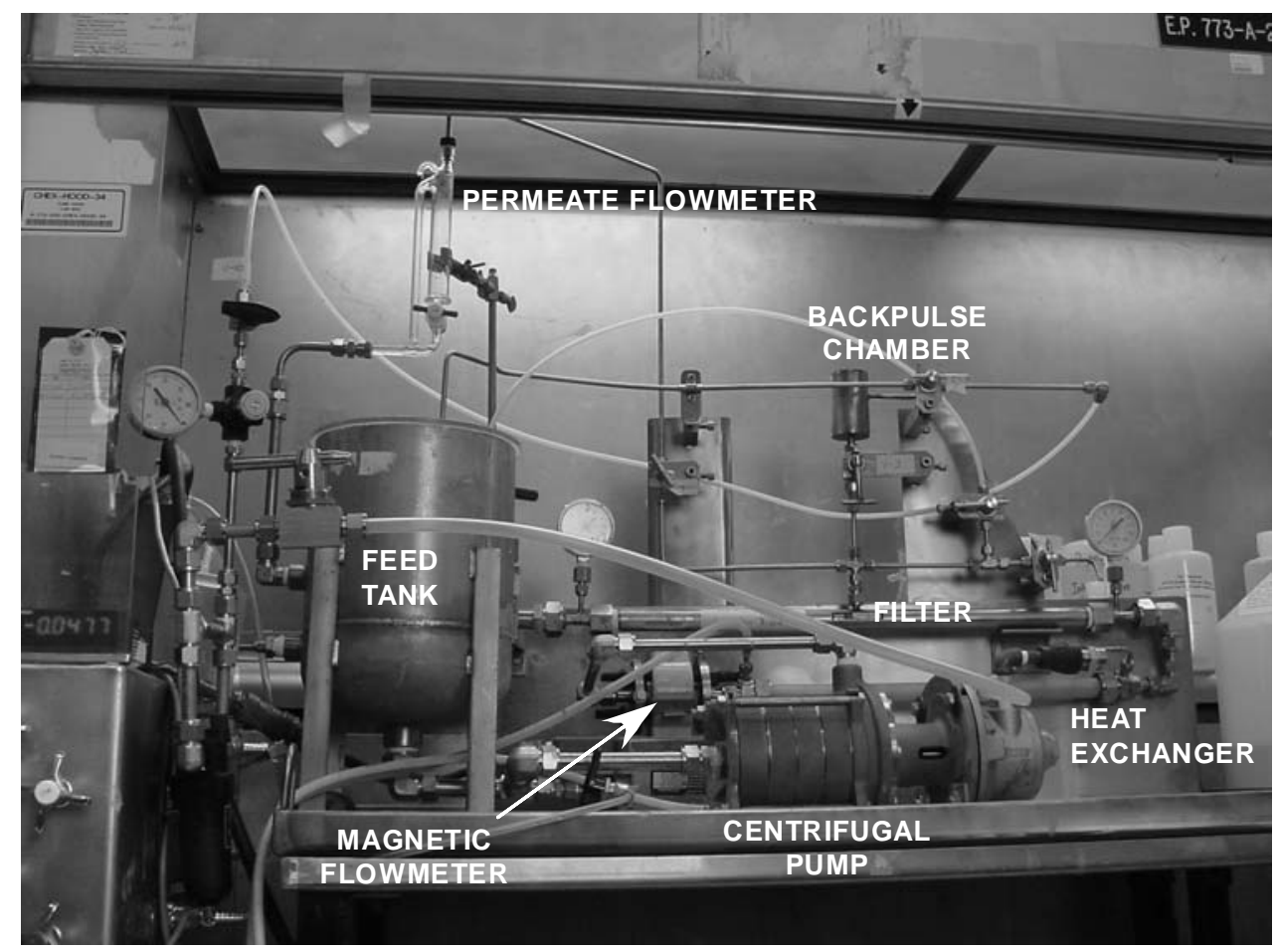

Figure 2.1 Crossflow Ultrafilter System 
WSRC-TR-2002-00108, Rev. 0

SRT-RPP-2002-00041, Rev. 0

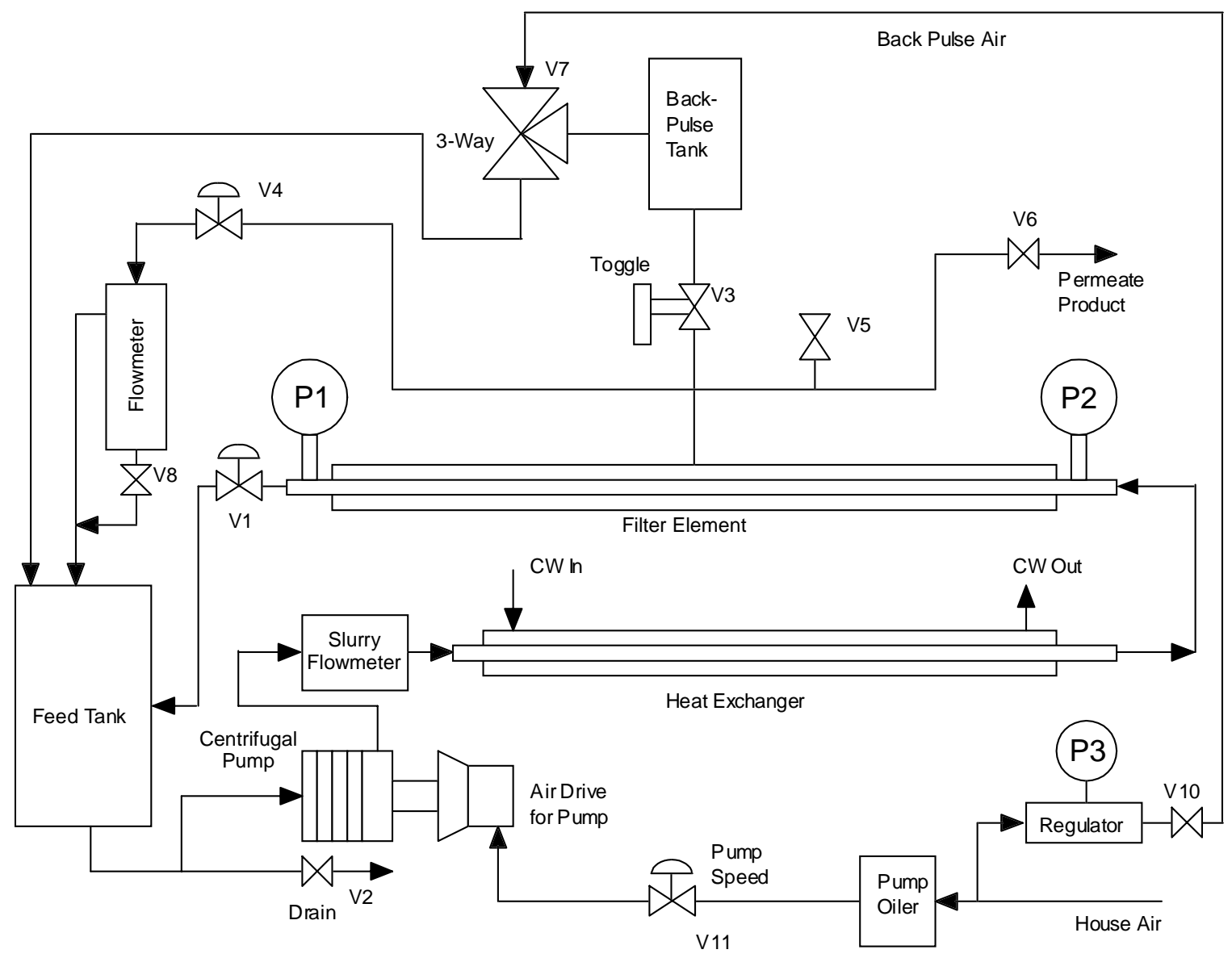

Figure 2.2 Cross-flow Filtration Schematic

\subsection{Experimental Methods \& Materials}

Initially, this work was specified to be performed with no insoluble solids, then respecified to include $0.1 \mathrm{wt} \%$ insoluble solids, then again respecified to use $3 \mathrm{wt} \%$ insoluble solids. Given these changes, to complete this work on a reasonable schedule, it was decided that the best way to proceed was to use the already made supernate simulant, some existing Envelope D solids simulant, and trim chemicals.

The simulant used for these experiments was made from a supernate simulant and a solids simulant. A simulated Tank 241-AZ-101 supernate solution that was $\sim 5 \mathrm{M}$ Na concentration was prepared using a slight modification of the Envelope B simulant recipe. ${ }^{4}$ The details of the recipe are given in Appendix 5.1. The solids used were an Envelope D simulant. ${ }^{4}$ The supernate simulant and the solids simulant were each analyzed prior to use to verify correct makeup. The solids simulant used was actually from three different bottles of previously made materials that were at different insoluble solids concentrations (8.03-14.8 wt\%). Note that concentration of these solids simulants to greater than $15 \mathrm{wt} \%$ insoluble solids by dead end filtration and centrifugation had been tried previously with no success, so they were used as is. The supernate simulant was mixed with calculated amounts of the solids simulants to 
achieve a total insoluble solids content of nominally $3.0 \mathrm{wt} \%$. Additional trim chemicals needed to be added to adjust the soluble solids concentrations to the correct values since the solids simulant had been washed to remove soluble components (e.g., Na, nitrite, nitrate, etc.). The amounts of each simulant material and chemicals used are shown in Table 2.1. The compositions of the simulant materials are shown in Appendix 5.2.

Table 2.1 Amounts of Simulants and Chemicals Used

\begin{tabular}{|l|c|c|}
\hline Material & $\begin{array}{c}\text { Insoluble Solids } \\
\mathrm{wt} \%\end{array}$ & $\begin{array}{c}\text { Amount } \\
\text { Used }\end{array}$ \\
\hline Supernate simulant & 0 & $4.0 \mathrm{~L}$ \\
\hline Solids simulant & 11.2 & $1.84 \mathrm{~L}$ \\
\hline Solids simulant & 14.8 & 0.25 \\
\hline Trim chemicals & 0 & $513 \mathrm{~g}$ \\
\hline Final Simulant & $\sim 3$ & $6.3 \mathrm{~L}$ \\
\hline
\end{tabular}

The supernate simulant was prepared to give an Al concentration of approximately $10700 \mathrm{mg} / \mathrm{L}$, but precipitation of aluminum as alumina occurred immediately. The $\mathrm{pH}$ was about 11.3 and the total hydroxide concentration was greater than 1.0M. Small amounts of Si and $\mathrm{Li}$ also appear to have precipitated. Analysis of precipitate from a previous attempt to prepare this simulant showed that the solids were predominantly gibbsite $\left[\mathrm{Al}(\mathrm{OH})_{3}\right], \mathrm{NaNO}_{2}$, $\mathrm{NaNO}_{3}$, and a trace amount of hydrogen aluminum silicate $\left[\mathrm{H}\left(\mathrm{AlSi}_{2} \mathrm{O}_{6}\right)\right]$. The actual supernate simulant Al concentration was $5070 \mathrm{mg} / \mathrm{L}$. Although aluminum precipitation could not be avoided, it was decided to continue with the experiments since the concentration of soluble aluminum in the simulant was deemed to have little effect on filtration. The supernate simulant was filtered prior to mixing with the solids simulants. Upon mixing the supernate simulant with the solids simulants and trim chemicals, the final composition shown in Table 2.2 was achieved. Note that the Al concentration is less than the original simulant. Aluminum was not added as a trim chemical, since it was suspected that additional precipitation would occur. 
WSRC-TR-2002-00108, Rev. 0

SRT-RPP-2002-00041, Rev. 0

Table 2.2 Measured Initial Composition of Simulant from Supernate, Solids, \& Trim Chemicals

\begin{tabular}{|c|c|c|c|c|c|c|c|c|}
\hline \multirow[t]{2}{*}{ Treatment: } & \multicolumn{2}{|c|}{$\begin{array}{l}\text { Filtrate } \\
\text { Filtered }\end{array}$} & \multicolumn{2}{|c|}{$\begin{array}{c}\text { Filtered Solids } \\
\text { Aqua Regia Dissolution }\end{array}$} & \multicolumn{4}{|c|}{$\begin{array}{c}\text { Total Sample } \\
\text { Microwave Dissolution }\end{array}$} \\
\hline & $\mathrm{mg} / \mathrm{L}$ & $\mathrm{mg} / \mathrm{L}$ & $\mathrm{mg} / \mathrm{kg}$ & $\mathrm{mg} / \mathrm{kg}$ & $\mathrm{mg} / \mathrm{L}$ & $\mathrm{mg} / \mathrm{L}$ & $\mathrm{mg} / \mathrm{L}$ & $\mathrm{mg} / \mathrm{L}$ \\
\hline ICPES: $\mathrm{Al}$ & 1970 & 2100 & 7289 & 7257 & 2694 & 2662 & 2678 & 2691 \\
\hline B & 20.2 & 28.1 & 544 & 461 & NA & NA & NA & NA \\
\hline $\mathrm{Ba}$ & $<0.12$ & $<0.12$ & 873 & 874 & 66.3 & 65.6 & 65.0 & 65.7 \\
\hline $\mathrm{Ca}$ & 0.404 & 0.812 & 2371 & 2342 & 185 & 182 & 179 & 177 \\
\hline $\mathrm{Cd}$ & 0.490 & 0.745 & 11120 & 11155 & 820 & 823 & 824 & 826 \\
\hline $\mathrm{Co}$ & $<0.44$ & $<0.44$ & 1425 & 1449 & 107 & 107 & 105 & 108 \\
\hline $\mathrm{Cr}$ & 443 & 454 & 1660 & 1684 & 551 & 562 & 559 & 564 \\
\hline $\mathrm{Cu}$ & $<0.5$ & $<0.5$ & 482 & 475 & 35.7 & 32.5 & 29.9 & 28.0 \\
\hline $\mathrm{Fe}$ & 0.560 & 0.952 & 142543 & 142434 & 10845 & 10898 & 10915 & 10895 \\
\hline $\mathrm{Li}$ & $<1$ & $<1$ & $<43$ & $<43$ & $<30$ & $<30$ & $<28$ & $<28$ \\
\hline $\mathrm{Mg}$ & $<0.84$ & $<0.84$ & 245 & 226 & $<25$ & $<25$ & $<23$ & $<23$ \\
\hline $\mathrm{Mn}$ & $<0.09$ & $<0.09$ & 3452 & 3452 & 287 & 289 & 261 & 261 \\
\hline Mo & 5.00 & 5.25 & $<43$ & $<43$ & 30.4 & 30.4 & 27.7 & 27.7 \\
\hline $\mathrm{Na}$ & 99600 & 105000 & 181250 & 176188 & 109955 & 106667 & 108417 & 107407 \\
\hline $\mathrm{Ni}$ & $<0.62$ & $<0.62$ & 8616 & 8691 & 682 & 681 & 690 & 688 \\
\hline $\mathrm{P}$ & 711 & 735 & 1240 & 1016 & 1031 & 1018 & 1052 & 1022 \\
\hline $\mathrm{Pb}$ & $<6.9$ & $<6.9$ & 1552 & 1585 & $<210$ & $<210$ & $<191$ & $<222$ \\
\hline $\mathrm{Si}$ & 3.70 & 4.40 & 3196 & 3064 & 6077 & 6115 & 5653 & 5366 \\
\hline $\mathrm{Sn}$ & $<2.6$ & $<2.6$ & $<112$ & $<112$ & $<79$ & $<79$ & $<72$ & $<72$ \\
\hline $\mathrm{Sr}$ & 0.165 & 0.170 & 428 & 422 & 97.6 & 97.0 & 31.7 & 32.1 \\
\hline $\mathrm{Ti}$ & $<1.4$ & $<1.4$ & 216 & 215 & $<42$ & $<42$ & $<39$ & $<39$ \\
\hline $\mathrm{V}$ & $<1.3$ & $<1.3$ & $<56$ & $<56$ & $<40$ & $<40$ & $<36$ & $<36$ \\
\hline $\mathrm{Zn}$ & $<3.7$ & $<3.7$ & 480 & 482 & $<112$ & $<112$ & $<102$ & $<102$ \\
\hline $\mathrm{Zr}$ & 0.997 & 2.15 & 42243 & 42785 & 3677 & 3669 & 3479 & 3496 \\
\hline $\mathrm{La}$ & $<7$ & $<7$ & 5578 & 5563 & 358 & 337 & 230 & 263 \\
\hline $\mathrm{K}$ & 3650 & 3920 & 5753 & 5864 & 3547 & 3509 & 3786 & 3451 \\
\hline $\operatorname{Re}$ & 33.2 & 34.4 & 52.7 & 62.3 & $<61$ & $<61$ & 64 & 64 \\
\hline $\mathrm{S}$ & 6190 & 6230 & 9429 & 9513 & 6572 & 6682 & 6719 & 6623 \\
\hline $\mathrm{Ag}$ & $<3$ & $<3$ & 599 & 841 & $<91$ & $<91$ & $<83$ & $<83$ \\
\hline $\mathrm{Ce}$ & $<7.7$ & $<7.7$ & 1243 & 1300 & $<234$ & $<234$ & $<213$ & $<213$ \\
\hline $\mathrm{Nd}$ & $<2.6$ & $<2.6$ & 3952 & 3992 & 390 & 316 & 300 & 319 \\
\hline IC: chloride & \multicolumn{2}{|c|}{194} & & & \multicolumn{2}{|r|}{231} & \multicolumn{2}{|r|}{200} \\
\hline fluoride & \multicolumn{2}{|c|}{1738} & & & \multicolumn{2}{|r|}{2011} & \multicolumn{2}{|c|}{1694} \\
\hline nitrate & \multicolumn{2}{|c|}{67107} & & & \multicolumn{2}{|c|}{75686} & \multicolumn{2}{|c|}{63905} \\
\hline nitrite & \multicolumn{2}{|c|}{54366} & & & \multicolumn{2}{|c|}{50080} & \multicolumn{2}{|c|}{61437} \\
\hline sulfate & \multicolumn{2}{|c|}{18123} & & & \multicolumn{2}{|c|}{20532} & \multicolumn{2}{|c|}{17019} \\
\hline phosphate & \multicolumn{2}{|c|}{2547} & & & \multicolumn{2}{|c|}{2358} & \multicolumn{2}{|c|}{2358} \\
\hline $\mathrm{TC}$ & & $\mathrm{TA}$ & & & & 4000 & & \\
\hline TIC & & $\mathrm{JA}$ & & & & 4000 & & \\
\hline TOC & & IA & & & & $<200$ & & \\
\hline Total Solic & $\mathrm{s}(\mathrm{wt} \%)$ & 26.5 & & & & & 8.0 & \\
\hline Insoluble Solic & $\mathrm{s}(\mathrm{wt} \%)$ & & & & & & 2.95 & \\
\hline Specific & Gravity & 1.22 & & & & & 1.25 & \\
\hline Numbers in rec & with < indic & ate values be & low detecti & imit & & & & \\
\hline
\end{tabular}


Samples of the slurry simulant and permeate were taken throughout the experiments. Some samples were analyzed completely, while others were analyzed only for total solids, insoluble solids, and specific gravity. Sample results from throughout the experiments are discussed in Section 3.1. The TBP and NPH used were 99.9+ \% pure. The NPH used was actually dodecane. The TBP and NPH were first mixed to a 50:50 wt \% mixture and then the mixture was added to the simulant in the necessary quantities.

\subsection{Experimental Runs Matrix}

The experimental runs were divided into four sections:

1. No organics. Factorial design. Permeate flux versus transmembrane pressure (TMP) and linear velocity. (Called "Level Z" herein.)

2. TBP and NPH both at $25 \mathrm{mg} / \mathrm{L}$ above the solubility limit. Factorial design as in \#1. (Called "Level L" herein.)

3. Increase TBP and NPH to as high as $2500 \mathrm{mg} / \mathrm{L}$ each to determine concentration (impact level) that adversely affects the filter flux. This is the "de minimis" concentration determination. (Called "Level M" herein.)

4. Organics at impact level. Factorial design as in \#1. (Called "Level H" herein.)

The factorial design for the no organics level is shown in Figure 2.3. Three clean water flux determination points are also shown in this Figure. The clean water flux was determined prior to the first runs with simulant sludge. The level $\mathrm{L}$ and level $\mathrm{H}$ designs are shown in Figure 2.4-Figure 2.5. The clean water flux was again determined after level $\mathrm{H}$ was completed. The numbers on each experimental point indicate the order in which the experiments were conducted; this order was randomly chosen for each level prior to the start of the experiments. Details of these experimental designs are given in Appendix 5.3.

Between each level, approximately two liters of permeate was collected for further use in ion exchange and evaporation experiments. For all three collection periods, the permeate was collected at a velocity of 13.4-15.9 fps, TMP of 32-39 psi, and a permeate flux of 0.061-0.095 gpm/ $\mathrm{ft}^{2}$. The Test Specification called for these production runs to be conducted at the optimum conditions of flow and pressure. The results of this work showed that the highest permeate flowrate was achieved at the highest attainable velocity and any pressure (above 20 psi, since lower pressures were not tested). 
WSRC-TR-2002-00108, Rev. 0

SRT-RPP-2002-00041, Rev. 0

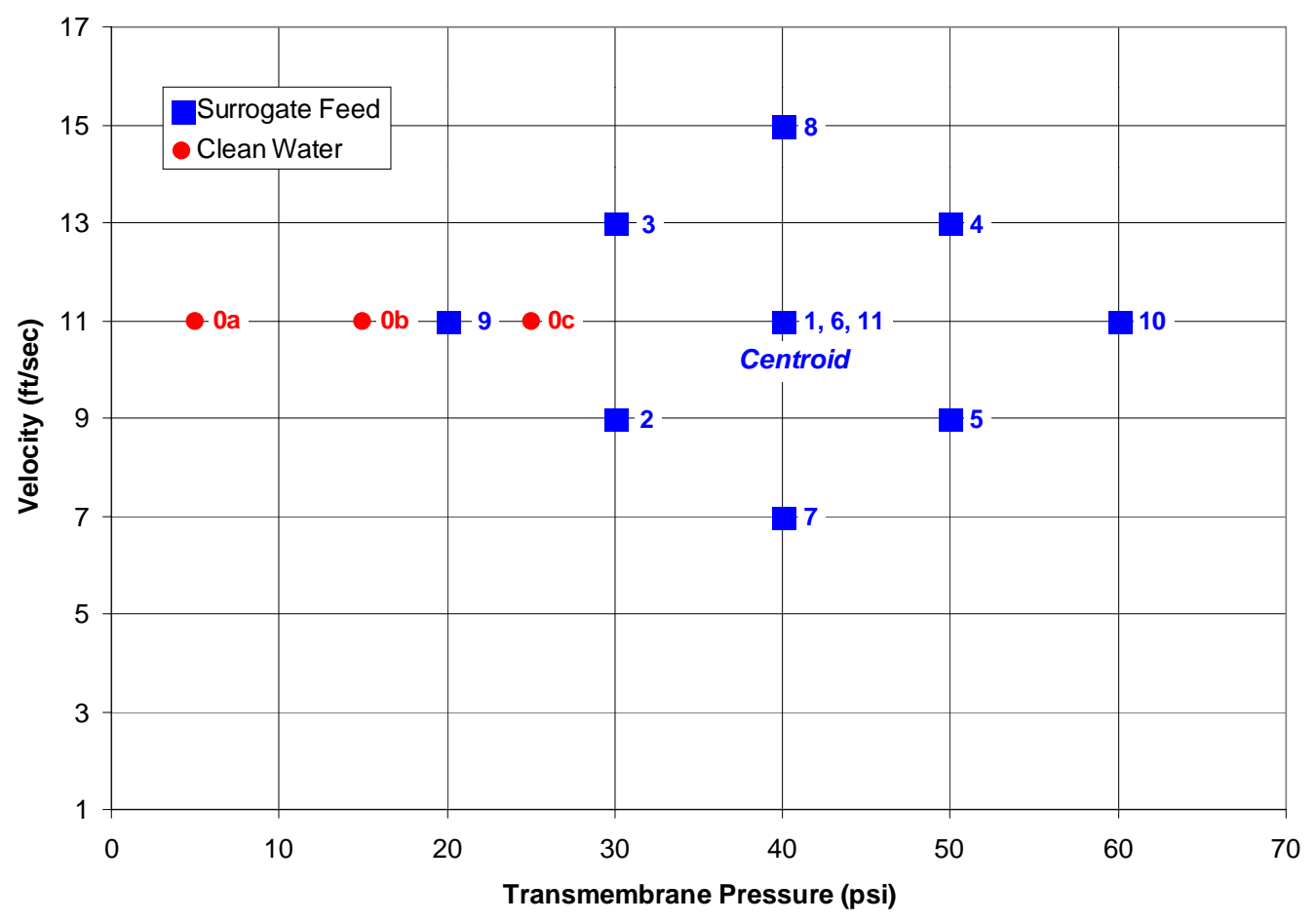

Figure 2.3 Level Z (No Organics) Factorial Design

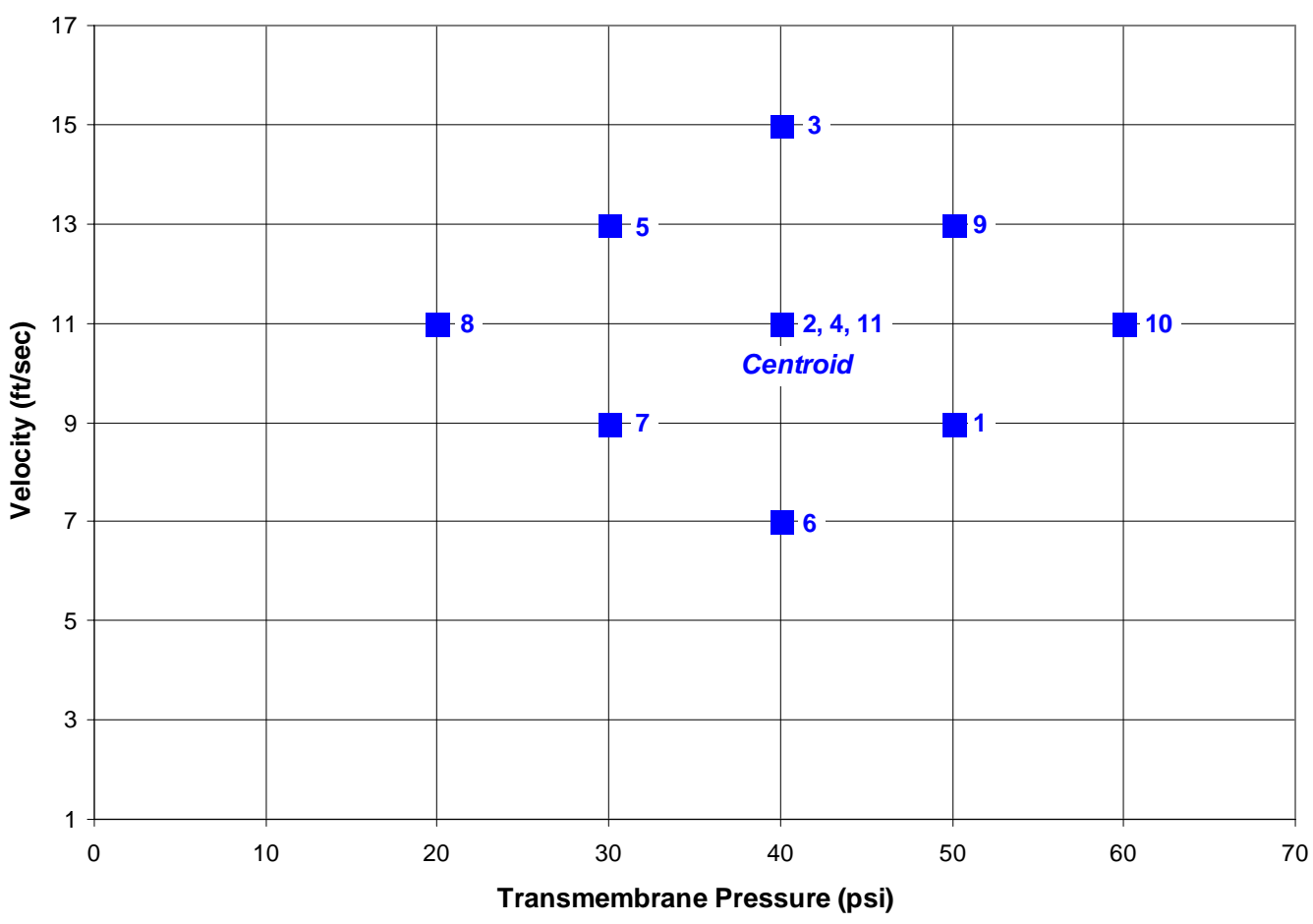

Figure 2.4 Level L (25 mg/L Each TBP \& NPH) Factorial Design 
WSRC-TR-2002-00108, Rev. 0

SRT-RPP-2002-00041, Rev. 0

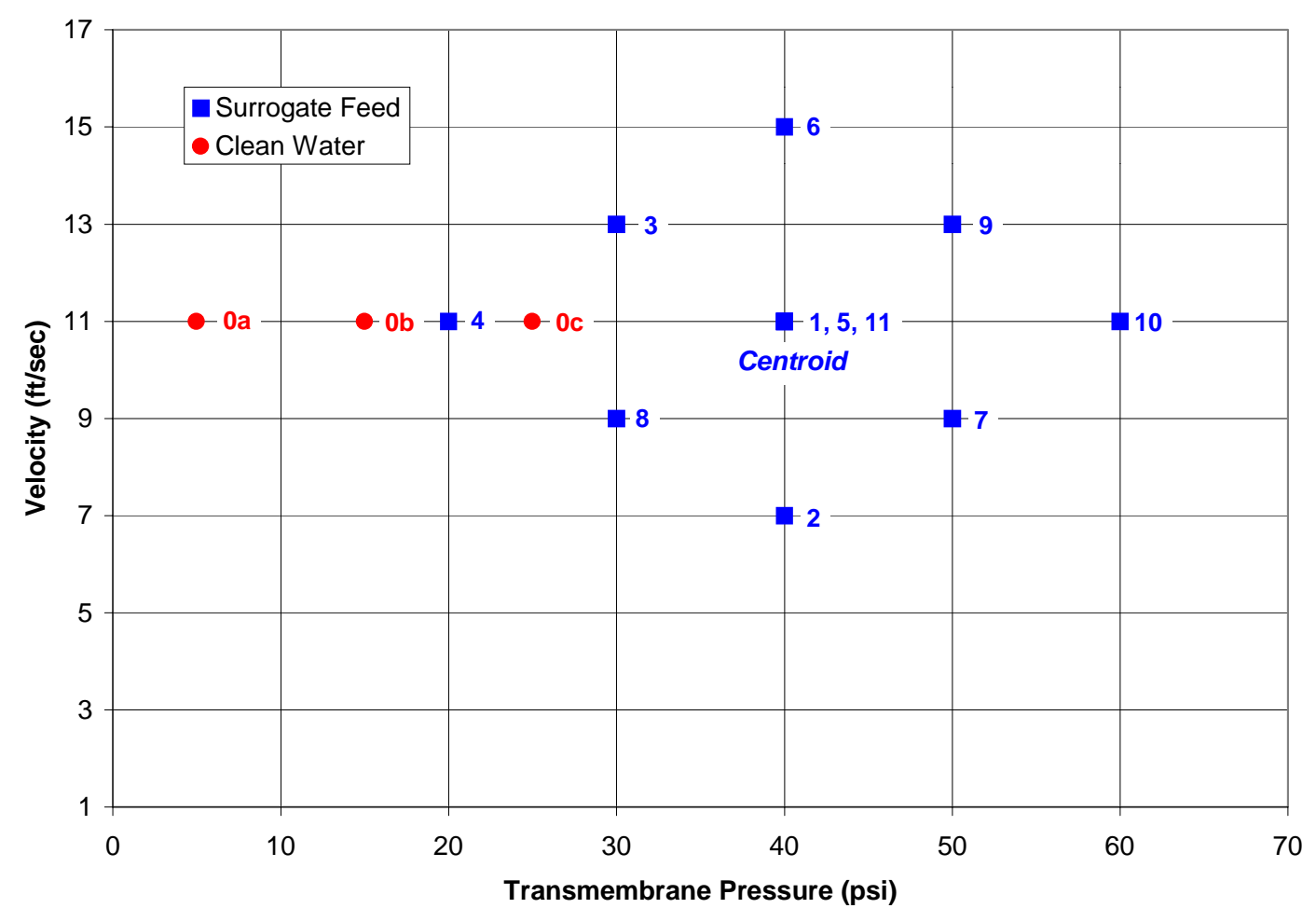

Figure 2.5 Level H (2500 mg/L Each TBP \& NPH) Factorial Design

\subsection{Results and Discussion}

\subsection{Experimental Data}

\subsubsection{Clean Water Flux}

Clean water fluxes were taken after the system was flushed with cleaning fluids as described in section 2.2.1. Transmembrane pressures were between 5 and 20 psi and fluxes were measured after initial backpulsing. The purpose for obtaining the clean water flux measurements is to ensure the equipment is cleaned and to establish a baseline filter flux to determine if filter fouling occurs during tests with the waste simulant sample. The high filtrate flux observed for water made it necessary to collect filtrate in a $500 \mathrm{ml}$ graduated cylinder instead of the $40 \mathrm{ml}$ graduated collection vessel used in slurry operation. Figure 3.1 presents the measured clean water flux prior to and after the experimentation. The clean water flux prior to the filtration of the Sr/TRU precipitate of Envelope $\mathrm{C}$ waste, on a similar ultrafilter, is also shown. ${ }^{5}$

The post-test clean water flux data was taken after the system had been cleaned as described in section 2.2.1, with the exceptions that the $0.01 \mathrm{M} \mathrm{NaOH}$ flush was not done and a flush with a low-foaming detergent (Alconox ${ }^{\mathrm{TM}}$ ) was performed. Soaking with $\sim 1 \mathrm{M}$ nitric acid for several days did not return the flux back to the original values, so the detergent was used on the assumption that the organics had affected the filter 
(although not adversely for slurry filtration). Both TBP and NPH are relatively stable in nitric acid (they are used in solvent extraction), so the apparent ineffectiveness of the nitric acid is not surprising since little organic degradation should occur.

After soaking with detergent, the system was flushed with water and then re-cleaned with nitric acid. At this time, significant foaming occurred, so the acid was left in the system for several weeks. After the additional soaking, the foaming stopped and the fluxes returned to values similar to before the run. There is no comparative cleaning data with an AZ-101 simulant without organics present to determine if the same difficulty in cleaning would have occurred.

Also note that the final feed used, at $2500 \mathrm{mg} / \mathrm{L}$ each of TBP and NPH, was much higher than would ever be expected in the WTP, so the effect of these organics may have been much more severe that will actually occur in the WTP. We recommend that the effect of separable organics on cleaning be investigated during filter cleaning tests.

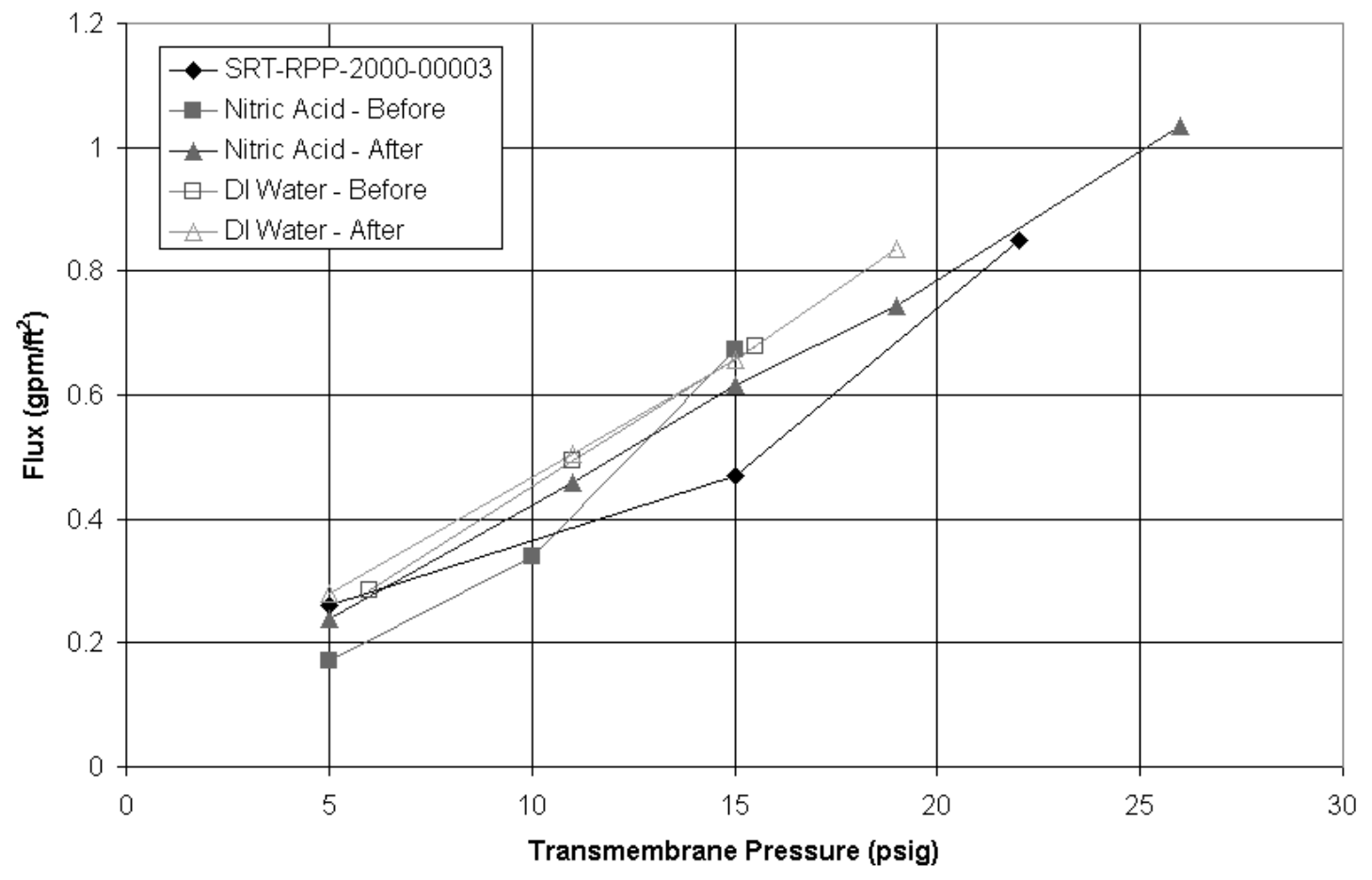

Figure 3.1 Clean Water Flux Prior to Experimentation

\subsubsection{Experimental Runs}

The no organics (Level Z) and the $25 \mathrm{mg} / \mathrm{L}$ each of TBP \& NPH experiments (Level L) were run in succession per the designs shown in Figure 2.3 and Figure 2.4. Upon completing level L, the organics content was incrementally increased from $25 \mathrm{mg} / \mathrm{L}$ each of TBP \& NPH to $2500 \mathrm{mg} / \mathrm{L}$ of each. The organics content was increased each time by adding the additional organics on top of the feed in the feed tank. The pump was then started and run for several minutes at $\sim 15 \mathrm{fps}$ velocity to mix the organics. 
The Test Plan specified that addition of organics cease when the "impact level" was found. However, no significant impact of the organics up to $2500 \mathrm{mg} / \mathrm{L}$ appeared to be found. The high organics (Level $\mathrm{H}$ ) factorial experiment, with both TBP and NPH at $2500 \mathrm{mg} / \mathrm{L}$, was then performed per the design shown in Figure 2.5.

The experimental fluxes measured for all levels of the factorial and impact level experiments are shown in Appendix 5.4. Plots of these same data are also shown in this Appendix. Figure 3.2 shows the factorial experiment arrangement with the actual variable values. The inability to achieve the highest flow/pressure combinations had no effect on the outcome of these tests. It should be noted that the multi-stage centrifugal pump should have been a six stage, rather than five stage pump.

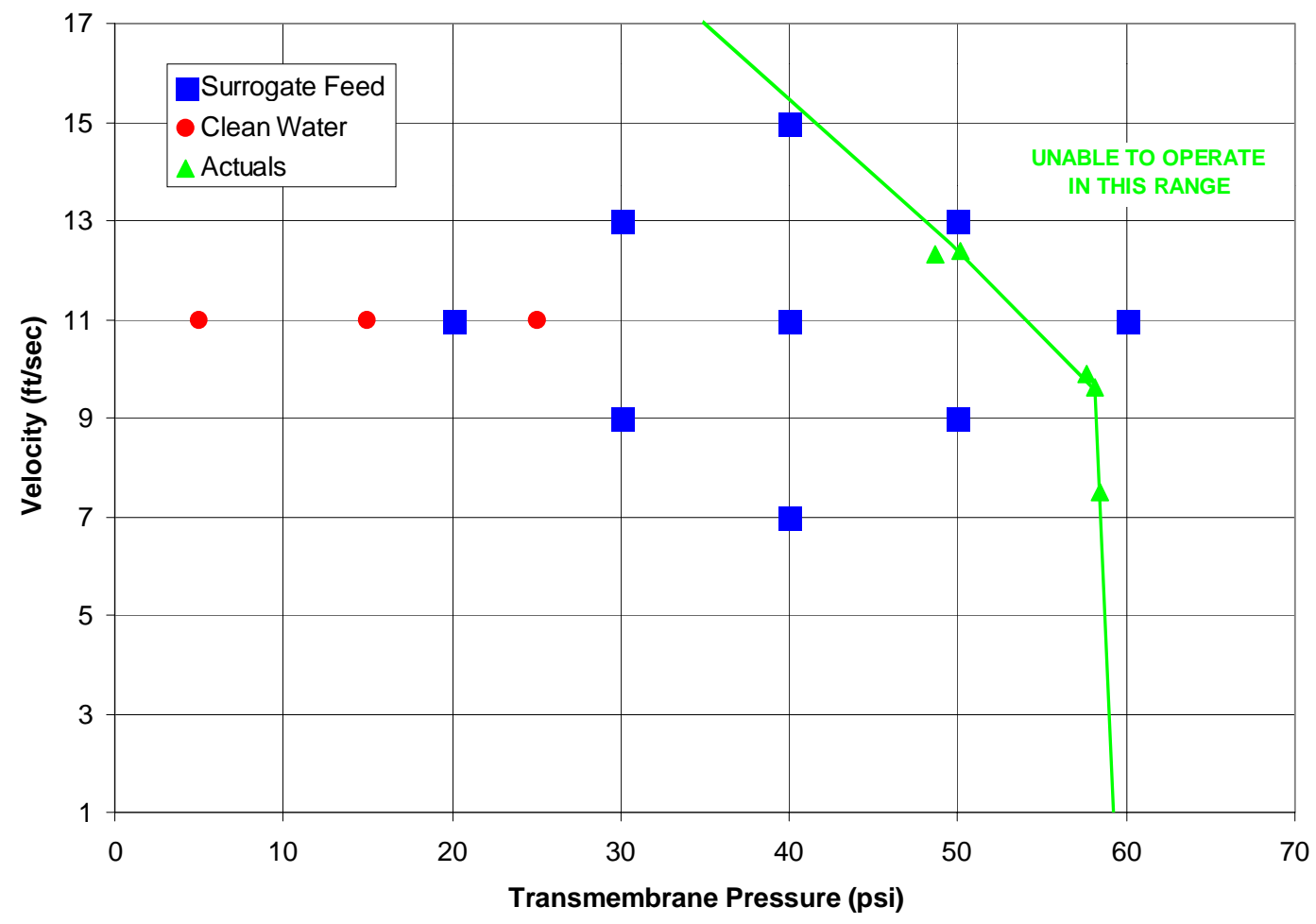

Figure 3.2 Factorial Data Points for All Levels

Because the factorial experiment used various combinations of TMP and velocity, direct graphical comparison of the data is somewhat difficult except where these variables are at the same values. Figure 3.3 shows the measured fluxes versus run number for the centroid point of the factorial experiments; this plot also includes the impact level determination data, which was also taken at the centroid. The minimum flux for Envelope B/D is $0.014 \mathrm{gpm} / \mathrm{ft}^{2}{ }^{6}$ During the Level L factorial experiment, the centrifugal pump began to leak from the mechanical seal. By the end of this level, the leak was too great to continue without repairs. To repair the pump, the system had to be drained and flushed. The flushing of the system resulted in a step change increase of about $0.006 \mathrm{gpm} / \mathrm{ft}^{2}$ in the steady state flux. Note the two data points that were run at the same conditions. To account for this change in flux, all of the flux data after the 
pump repair was decreased by $0.006 \mathrm{gpm} / \mathrm{ft}^{2}$ to put this data on the same basis as the initial data.

The steady state flux decreased approximately linearly until the beginning of the impact level (M) determination runs. This type of behavior has been seen in other ultrafiltration work at SRTC. ${ }^{7}$ The cause for this type of trend has been attributed to either irreversible (except with cleaning) changes in the filter membrane or particle degradation to an ultimate particle size distribution. ${ }^{8}$ Both of these proposed phenomena are functions primarily of run time.

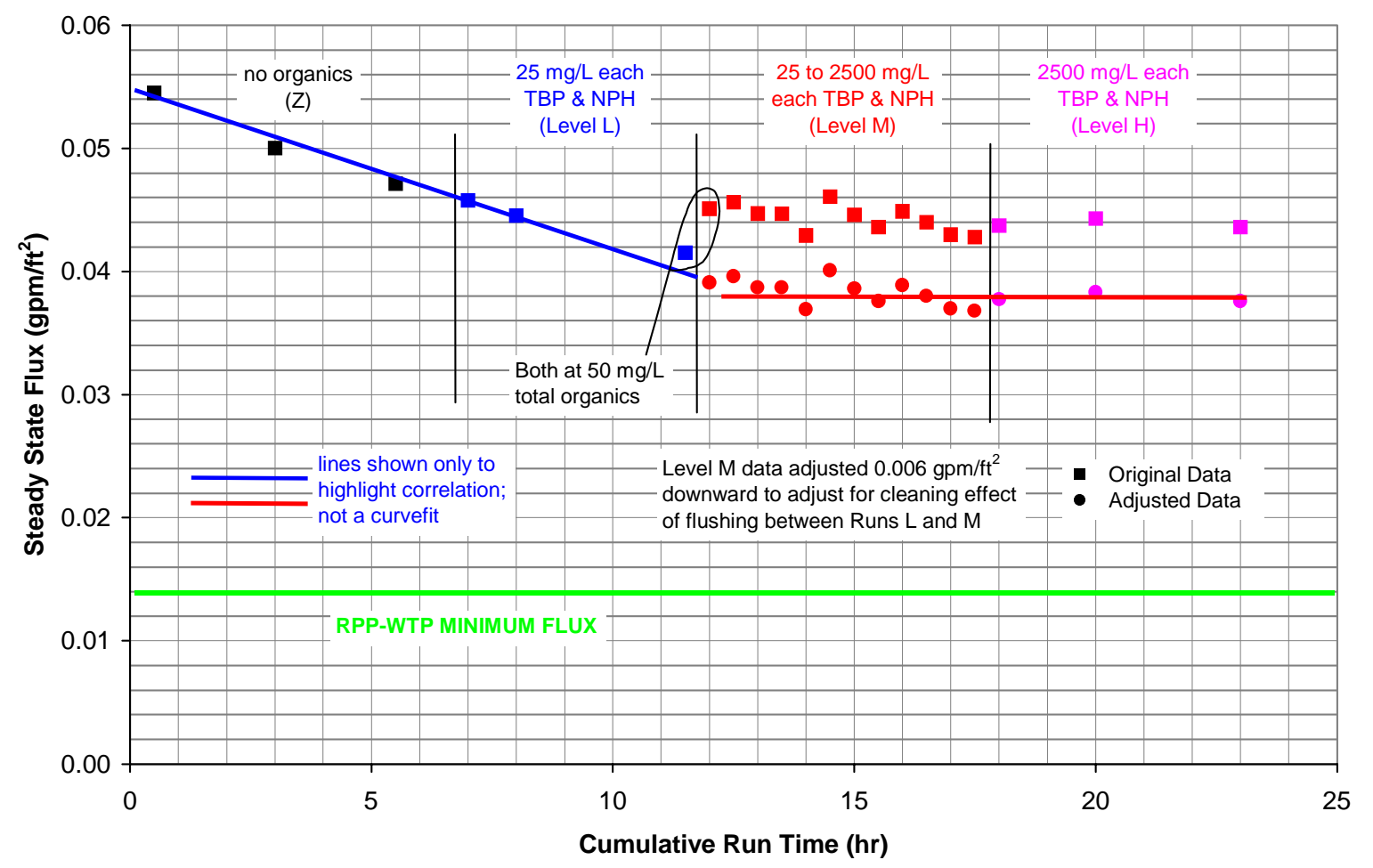

Figure 3.3 All Centroid Flux Data

\subsection{Simulant and Permeate Composition Versus Time}

The total solids and suspended (insoluble) solids contents and the specific gravity of the simulant sludge and permeate was measured periodically. More complete analyses of the composition of the simulant were made between each level of experiment. Figure 3.4 shows the total solids, suspended solids, and specific gravity of the slurry throughout the experiments. The total solids content ranged from about 27.5 to $29.0 \mathrm{wt} \%$ during the factorial experiments, and increased during the concentration steps. These data are also summarized in Figure 3.5. Overall, there was a slight increase in all three quantities from level to level. These differences are due to the way each level was started. Upon completion of the concentration step from the previous level, supernate simulant was re-added to the feed tank in the approximate amount that had been removed. The variation in the amounts of these additions is the reason for the different solids and specific gravity measurements. 
WSRC-TR-2002-00108, Rev. 0

SRT-RPP-2002-00041, Rev. 0

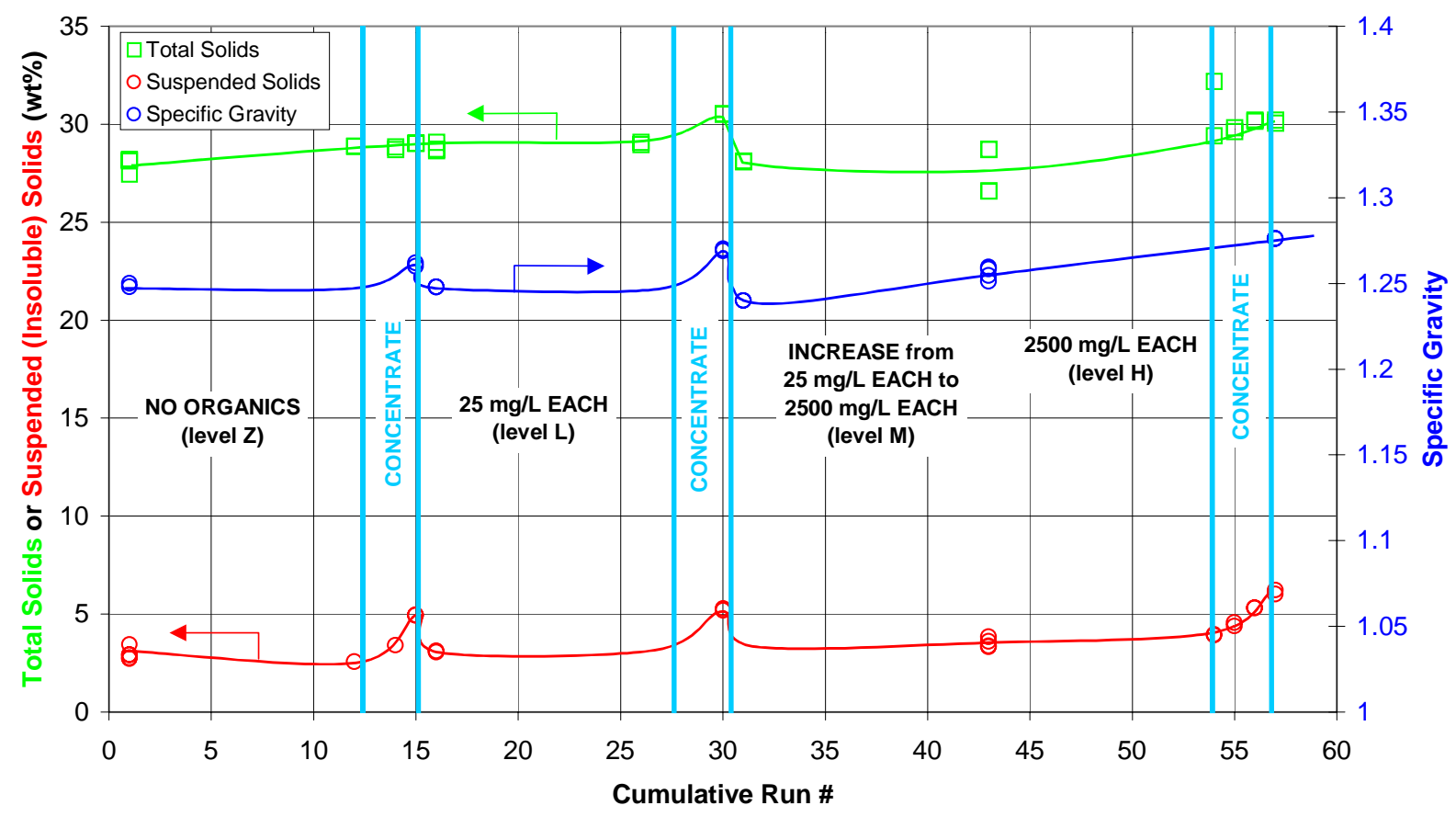

Figure 3.4 Total Solids, Suspended Solids, and Specific Gravity versus Run

The composition of the slurry, permeate (or filtrate from slurry samples), and the filtered solids are shown in Table 3.1. Most of the analyses of the slurry from level to level are consistent and generally within 20\%. Different types of dissolutions were sometimes necessary for the elemental analyses to dissolve the entire sample. The microwave dissolution was usually used, but the peroxide fusion and aqua regia dissolutions were also used.

Since the main purpose of this work was to determine if the presence of the TBP and NPH have any effect on the filtrate flux, it was important to eliminate other possible causes for the data behavior. Dissolution or precipitation of selected species could have a significant effect on the filterability of the slurry. Figure 3.6-Figure 3.8 show the slurry and permeate IC and carbon analyses plotted versus cumulative run number. Note that some of the variation seen is due to slightly different solids concentrations that existed during the different levels. There were several unexpected trends. The phosphate concentration in both the slurry and permeate appears to have dropped off during the high organics runs. An increase in phosphorus was expected with the addition of the TBP; however, the difficulty in getting a representative sample containing the organic phase contributed to this trend (see discussion in Section 3.3). The hydroxide concentration also dropped off during the experiments, starting at about $0.97 \mathrm{M}$ and dropping to about 0.8M. In Figure 3.9-Figure 3.10, the IC and TIC/TOC data is shown in $\mathrm{mg} / \mathrm{L}$ and Molar, respectively, where all concentrations have been normalized to a constant nitrate concentration. Nitrate concentration was not expected to change except for dilution effects. These figures show that when normalized to nitrate, the concentrations of sulfate, chloride, and fluoride stay essentially constant. The graph of Molar concentration shows that the decrease in the hydroxide concentration is, to within the analytical accuracy, balanced by the increase in the carbonate concentration. Therefore, absorption of carbon dioxide appears to account for the hydroxide decrease. 
WSRC-TR-2002-00108, Rev. 0

SRT-RPP-2002-00041, Rev. 0

The data in Figure 3.11 show that the iron concentration was relatively constant during the factorial experiments and that it increased during the concentration, as expected. Iron was the major insoluble species in the slurry. The other significant insoluble species were $\mathrm{Zr}$, and $\mathrm{Si}$; the data for both of these is inconclusive. The dissolution of $\mathrm{Zr}$ by the microwave and aqua regia methods gave inconsistent results, whereas there was significant scatter in the $\mathrm{Si}$ data. The soluble species $\mathrm{Na}, \mathrm{Al}, \mathrm{Cr}$, and $\mathrm{K}$ all stayed relatively constant as expected.

Since $\mathrm{Zr}$ and Fe were mostly insoluble, their concentrations in the slurry should parallel the suspended solids concentration. The ratio of these elements to the TSS is shown in Figure 3.12. The ratios, within experimental variation, are constant.

Figure 3.8 shows the carbon analyses during the experiments. There is good agreement between the TIC and carbonate analyses (although a constant offset) and also between the TOC analyses and the TOC calculated from the organics added (except for the last data point). The TOC calculated from the organics measured by GC-MS was generally about 1/3 of the actual amount added. This discrepancy can be explained by the difficulty in getting a representative sample of the slurry/organic phase mixture, which is discussed in Section 3.3. The average analyses of filtrate from slurry and permeate were shown in Figure 3.2. The composition of the permeate varied little during the experiments, as shown in Table 3.2. The first two columns and the last column are data for dead-end filtered slurry. 
WSRC-TR-2002-00108, Rev. 0

SRT-RPP-2002-00041, Rev. 0

Table 3.1 Average Compositions of Slurry, Permeate, and Solids

\begin{tabular}{|c|c|c|c|c|c|c|c|c|}
\hline & $\begin{array}{c}\text { Filtrate or } \\
\text { Permeate } \\
\text { mg/L }\end{array}$ & $\begin{array}{l}\text { Sludge } \\
\text { Solids } \\
\text { mg/L }\end{array}$ & $\begin{array}{c}\text { Slurry - } \\
\text { Level Z Start } \\
\text { mg/L }\end{array}$ & $\begin{array}{c}\text { Slurry - } \\
\text { Level Z } \\
\text { Concentrated } \\
\text { mg/L }\end{array}$ & $\begin{array}{c}\text { Slurry - } \\
\text { Level L } \\
\text { Start } \\
\text { mg/L }\end{array}$ & $\begin{array}{c}\text { Slurry - } \\
\text { Level L } \\
\text { Concentrated } \\
\text { mg/L }\end{array}$ & $\begin{array}{c}\text { Slurry - } \\
\text { Level H } \\
\text { Start } \\
\text { mg/L }\end{array}$ & $\begin{array}{c}\text { Slurry - } \\
\text { Level H } \\
\text { Concentrated } \\
\text { mg/L }\end{array}$ \\
\hline $\mathrm{Al}$ & 2339 & 7273 & 2681 & 2862 & 3038 & 3356 & 2782 & NA \\
\hline B & 21.4 & 503 & NA & NA & NA & NA & $<29.6$ & 621 \\
\hline $\mathrm{Ba}$ & 0.23 & 931 & 66 & 94 & 70.8 & 103 & 297 & 149 \\
\hline $\mathrm{Ca}$ & $<0.47$ & 3131 & 181 & 256 & 196 & 277 & 180 & 1054 \\
\hline $\mathrm{Cd}$ & 0.87 & 11128 & 823 & 1189 & 887 & 1300 & 831 & 1664 \\
\hline $\mathrm{Co}$ & $<0.44$ & 1459 & 106 & 156 & 118 & 167 & 108 & 219 \\
\hline $\mathrm{Cr}$ & 525 & 1803 & 559 & 589 & 649 & 710 & 624 & 737 \\
\hline $\mathrm{Cu}$ & $<0.50$ & 378 & 32 & 44 & 42.8 & 43.8 & 30.0 & $<18.8$ \\
\hline $\mathrm{Fe}$ & 3.58 & 144878 & 10888 & 15394 & 11548 & 17076 & 10852 & 21717 \\
\hline $\mathrm{Li}$ & $<1.00$ & $<71$ & $<29$ & $<29$ & $<30.8$ & $<30.1$ & $<14.1$ & $<37.5$ \\
\hline $\mathrm{Mg}$ & $<0.84$ & 248 & $<24$ & $<25$ & $<25.9$ & $<25.3$ & $<17.1$ & $<73.8$ \\
\hline $\mathrm{Mn}$ & $<0.13$ & 3592 & 274 & 380 & 289 & 411 & 272 & 541 \\
\hline Mo & 4.51 & $<71$ & $<29$ & $<31$ & $<32.5$ & $<30.1$ & $<14.1$ & $<37.5$ \\
\hline $\mathrm{Na}$ & 110622 & 178719 & 108112 & 108213 & 112206 & 114892 & 112549 & NA \\
\hline $\mathrm{Ni}$ & $<0.71$ & 8809 & 685 & 960 & 732 & 1058 & 665 & 1364 \\
\hline $\mathrm{P}$ & 742 & 2343 & 1031 & 1069 & 968 & 991 & 395 & 862 \\
\hline $\mathrm{Pb}$ & $<6.90$ & 1717 & $<208$ & 207 & $<213$ & 217 & 163 & 270 \\
\hline $\mathrm{Si}$ & 3.55 & 5247 & 5803 & 3838 & 5292 & 5421 & NA & 5801 \\
\hline $\mathrm{Sn}$ & $<2.60$ & $<184$ & $<76$ & $<75$ & $<80.2$ & $<78.2$ & $<36.6$ & $<97.5$ \\
\hline $\mathrm{Sr}$ & $<0.12$ & 444 & 65 & 60 & 46.8 & 48.6 & 40 & NA \\
\hline $\mathrm{Ti}$ & $<1.40$ & 259 & $<41$ & $<43$ & $<43.2$ & $<42.1$ & $<20.2$ & $<191$ \\
\hline V & $<1.30$ & $<92$ & $<38$ & $<37$ & $<40.1$ & $<39.1$ & $<18.3$ & $<48.8$ \\
\hline $\mathrm{Zn}$ & $<3.70$ & 513 & $<107$ & $<106$ & $<114$ & $<111$ & $<52.1$ & $<139$ \\
\hline $\mathrm{Zr}$ & 3.45 & 42514 & 3580 & 4970 & 3786 & 5494 & 2999 & NA \\
\hline $\mathrm{La}$ & $<7.00$ & 5510 & 297 & 361 & 324 & 498 & 440 & 893 \\
\hline K & 4141 & 5809 & 3573 & 3534 & 3619 & 3842 & 3768 & NA \\
\hline $\operatorname{Re}$ & 38.0 & 127 & $<63$ & $<58$ & $<62.0$ & $<81.0$ & $<70.4$ & $<37.5$ \\
\hline $\mathrm{S}$ & 6386 & 9405 & 6649 & 6557 & 6654 & 6635 & 7105 & 6991 \\
\hline $\mathrm{Ag}$ & $<3.00$ & 1226 & $<87$ & $<144$ & $<92.5$ & $<150$ & $<73.8$ & $<313$ \\
\hline $\mathrm{Ce}$ & $<7.70$ & 1326 & $<224$ & $<222$ & $<237$ & $<232$ & $<119$ & $<289$ \\
\hline $\mathrm{Nd}$ & $<2.60$ & 3921 & 331 & 380 & 365 & 476 & 288 & 603 \\
\hline chloride & 164 & NA & 215 & 221 & 207 & 221 & 161 & 155 \\
\hline fluoride & 1629 & NA & 1852 & 1888 & 1866 & 1973 & 1793 & 1705 \\
\hline nitrate & 62749 & NA & 69795 & 70394 & 73099 & 77174 & 69285 & 66567 \\
\hline nitrite & 49750 & NA & 55758 & 55171 & 57827 & 61918 & 58525 & 59140 \\
\hline sulfate & 16286 & NA & 18776 & 17332 & 18714 & 19701 & 17207 & 16302 \\
\hline phosphate & 2108 & NA & 2358 & 2424 & 2167 & 2276 & 1655 & 1325 \\
\hline carbonate & NA & NA & 22302 & 24105 & 24432 & 29403 & 27588 & 27690 \\
\hline hydroxide & NA & NA & 17061 & 16426 & 16394 & 14799 & 13782 & 13336 \\
\hline TS (wt\%) & 27.25 & NA & 28.04 & 29.04 & 28.8 & 30.5 & 27.7 & 30.1 \\
\hline TSS (wt\%) & NA & NA & 2.95 & 4.93 & 3.08 & 5.23 & 3.53 & 6.12 \\
\hline SpGr & 1.235 & NA & 1.249 & 1.261 & 1.25 & 1.27 & 1.26 & 1.28 \\
\hline
\end{tabular}


WSRC-TR-2002-00108, Rev. 0

SRT-RPP-2002-00041, Rev. 0

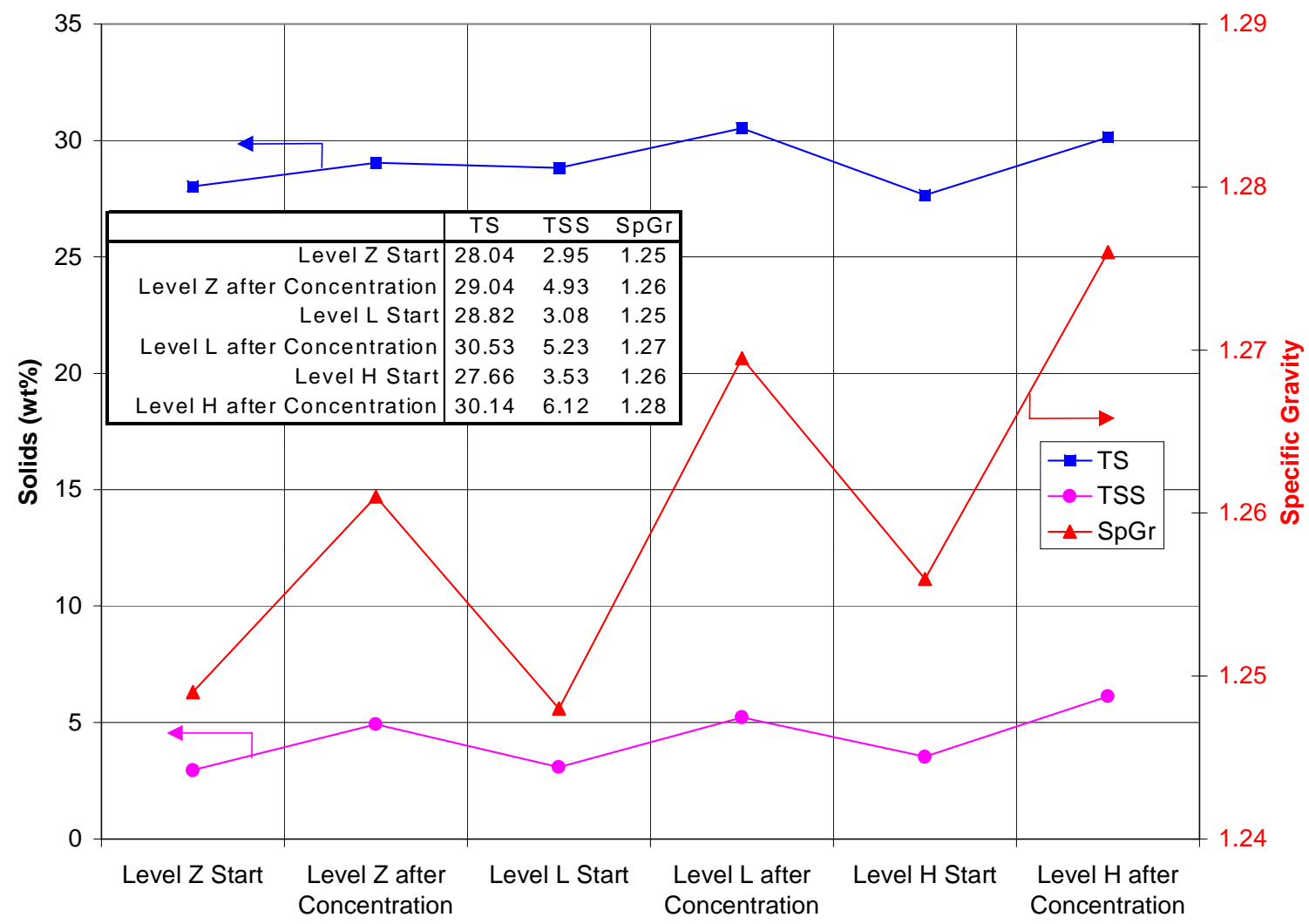

Figure 3.5 Total Solids, Suspended Solids, and Specific Gravity versus Level

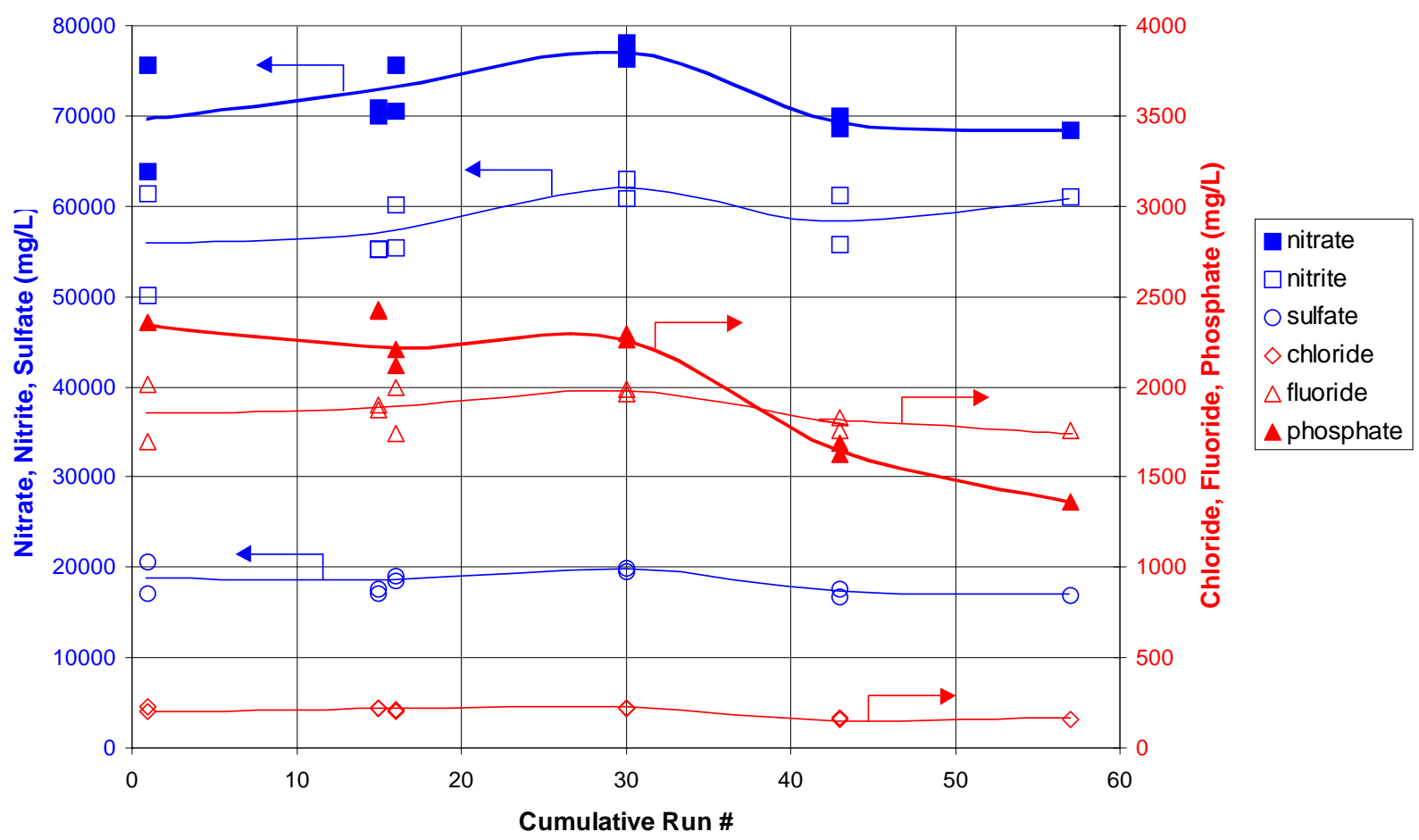

Figure 3.6 Ion Chromatography Data for Slurry Samples 
WSRC-TR-2002-00108, Rev. 0

SRT-RPP-2002-00041, Rev. 0

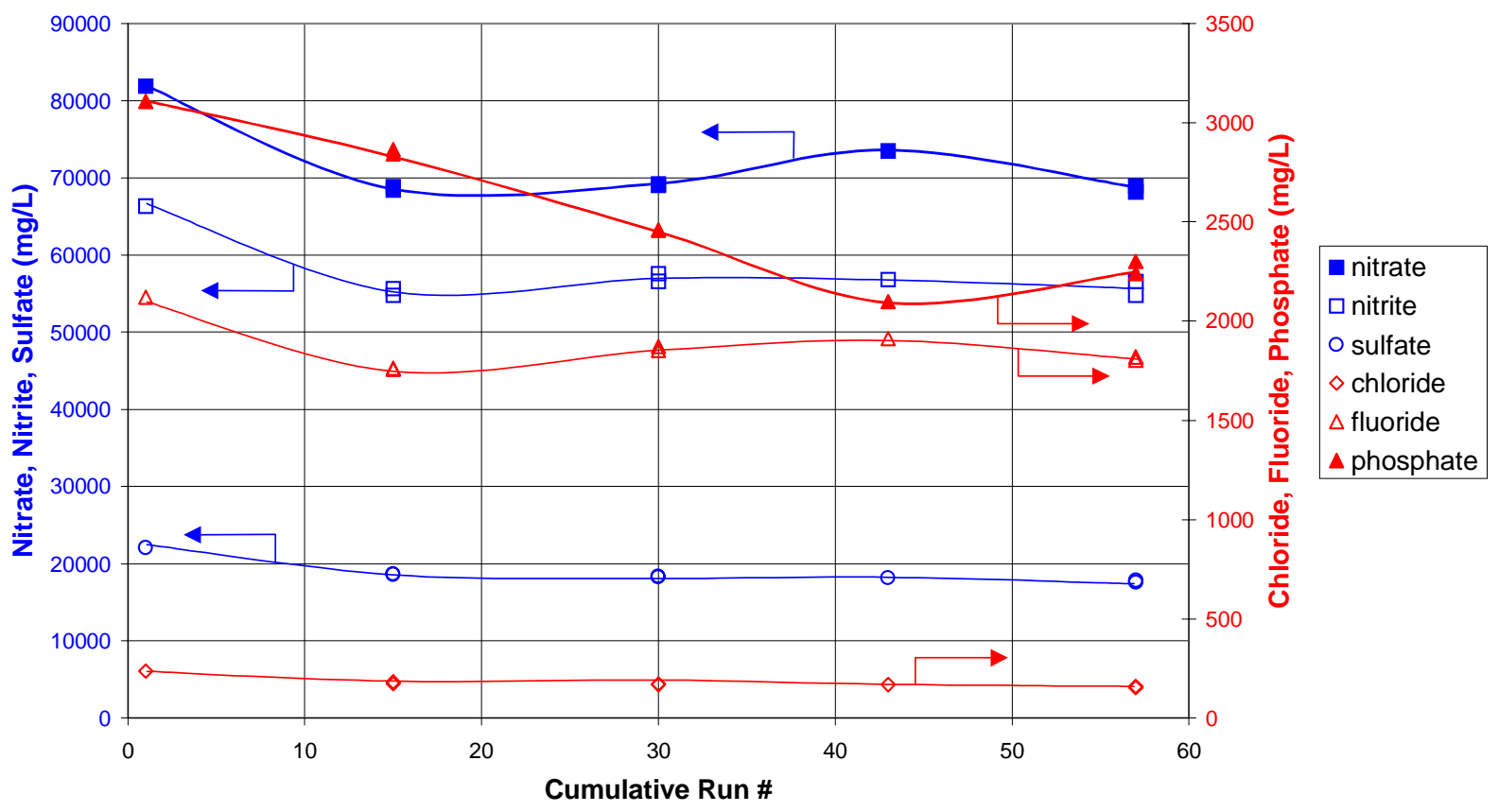

Figure 3.7 Ion Chromatography Data for Permeate

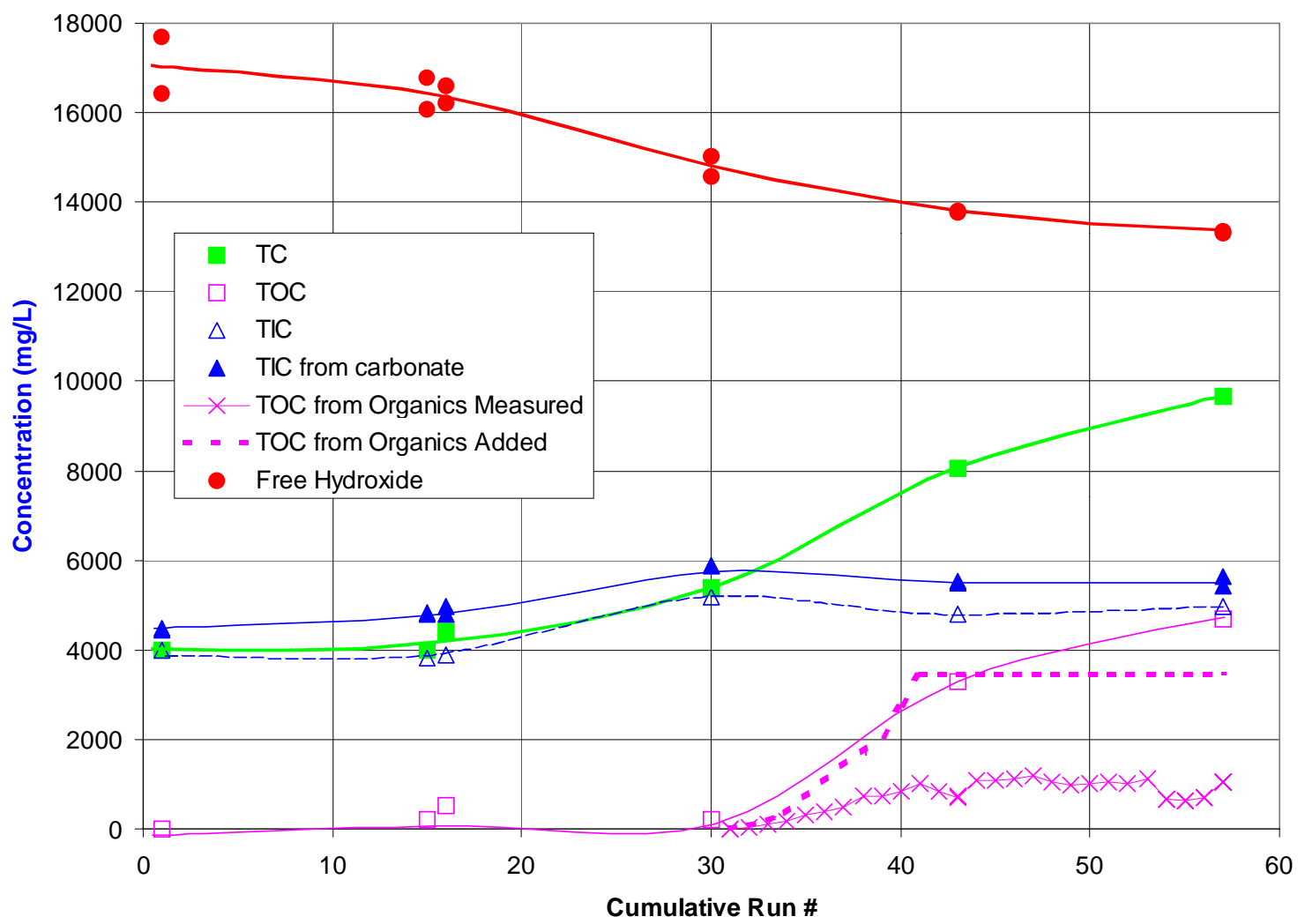

Figure 3.8 Slurry Carbon and Free Hydroxide Analyses 
WSRC-TR-2002-00108, Rev. 0

SRT-RPP-2002-00041, Rev. 0

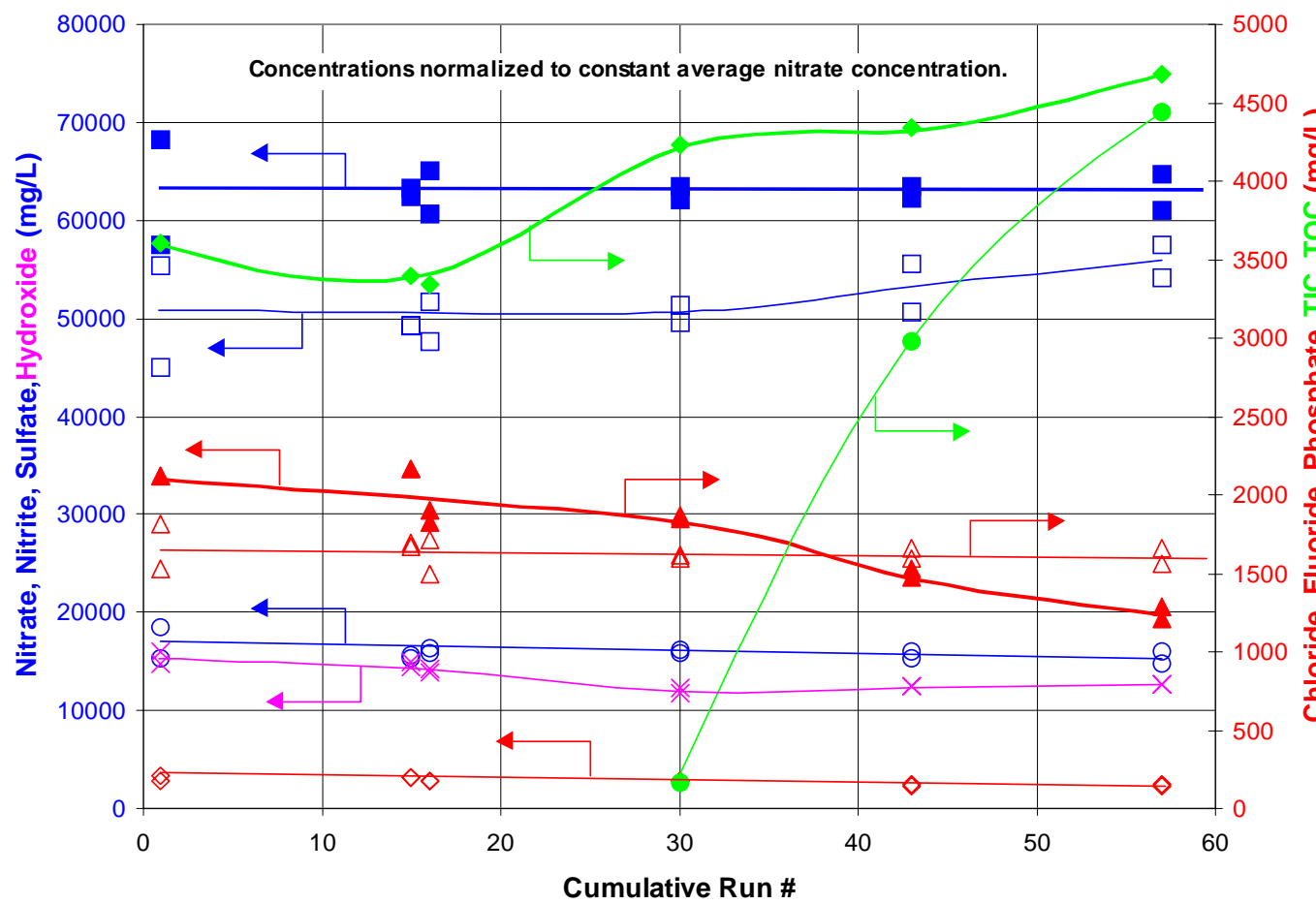

nitrate

$\square$ nitrite

O sulfate

$\times$ hydroxide

$\diamond$ chloride

$\triangle$ fluoride

$\triangle$ phosphate

- TOC

$\rightarrow \mathrm{TIC}$

Figure 3.9 IC, Hydroxide, and TIC/TOC mg/L Data

Normalized to Constant Average Nitrate

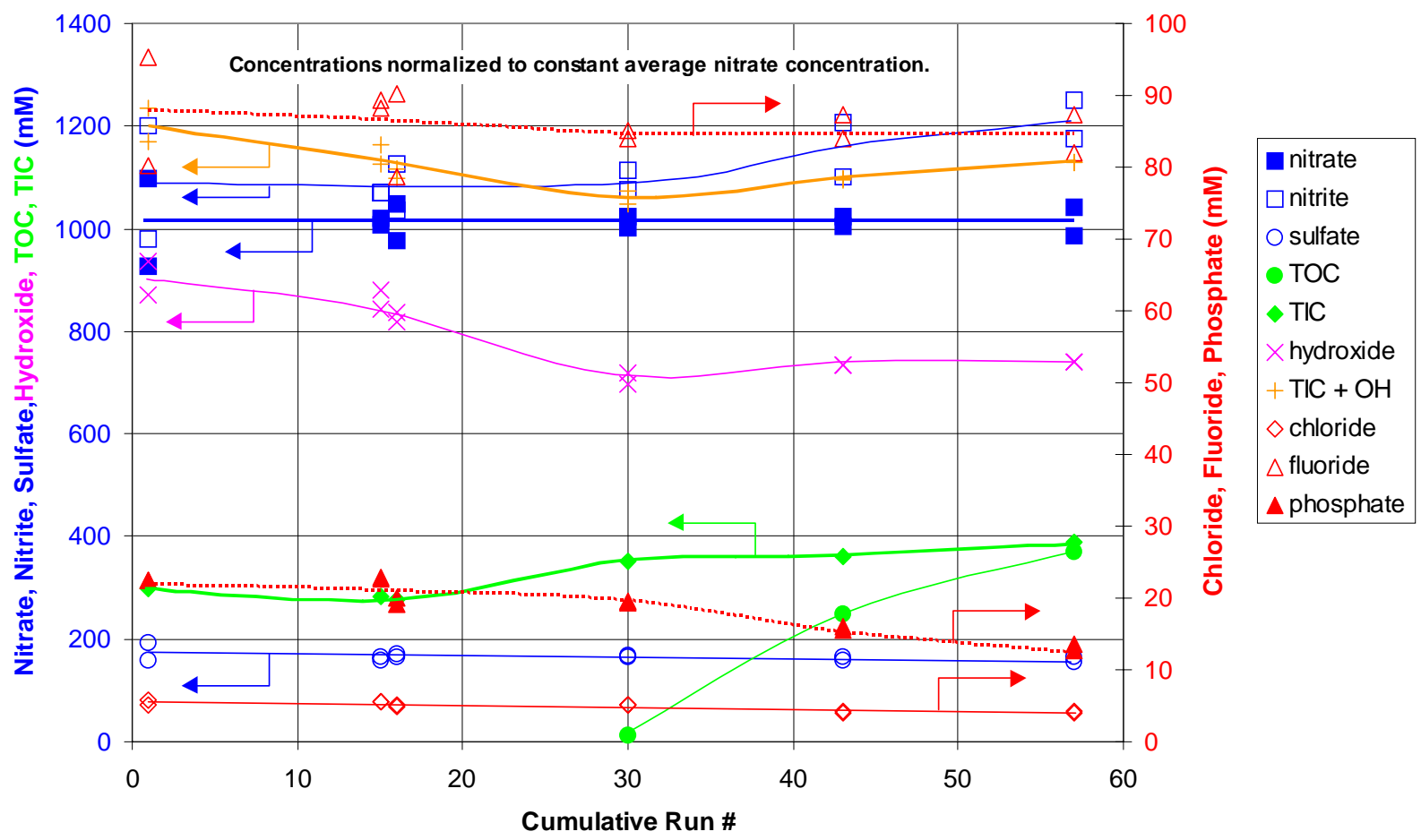

Figure 3.10 IC, Hydroxide, and TIC/TOC Molar Data Normalized to Constant Average Nitrate 
WSRC-TR-2002-00108, Rev. 0

SRT-RPP-2002-00041, Rev. 0

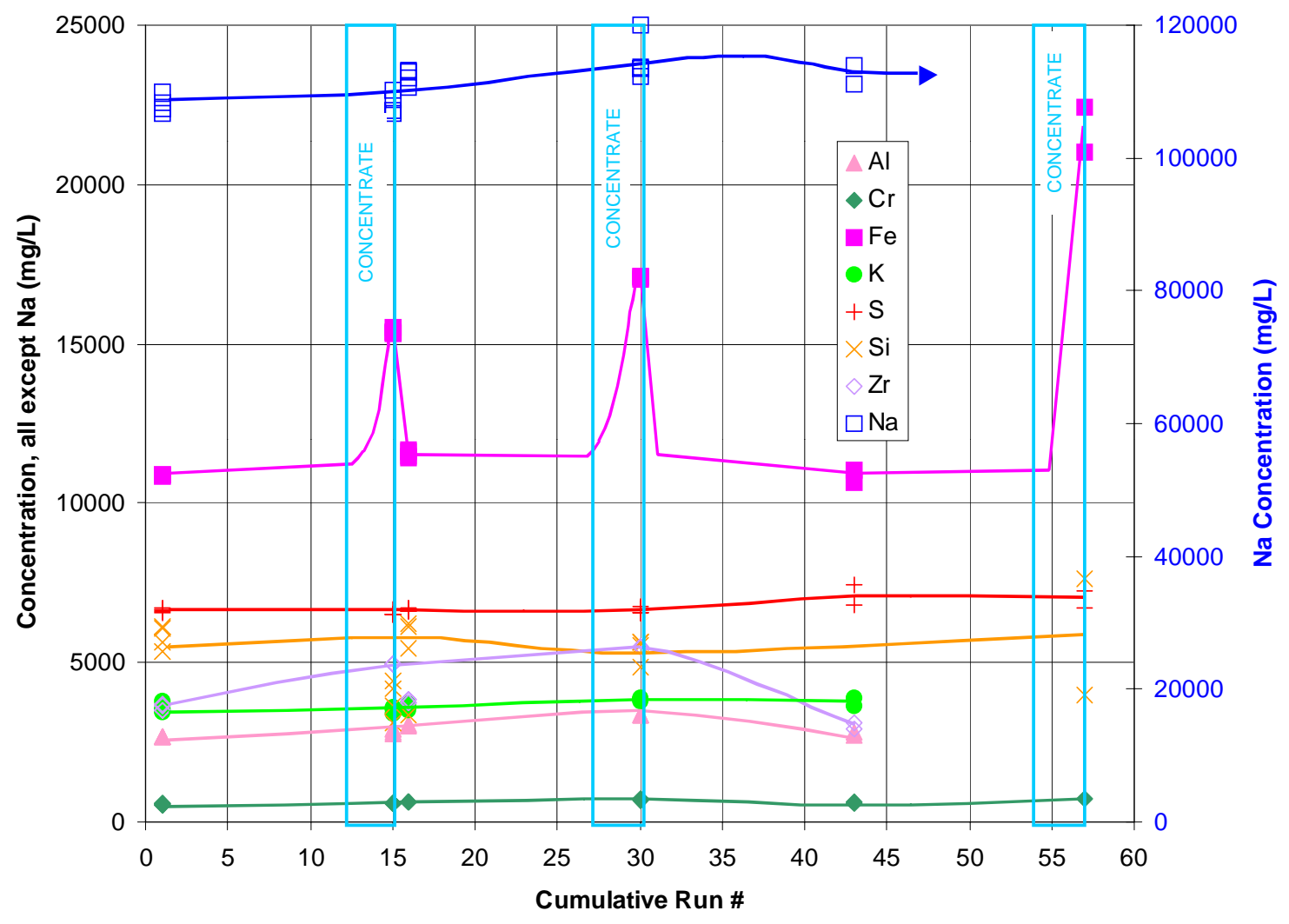

Figure 3.11 Elemental Analyses (by ICPES) for Major Metals

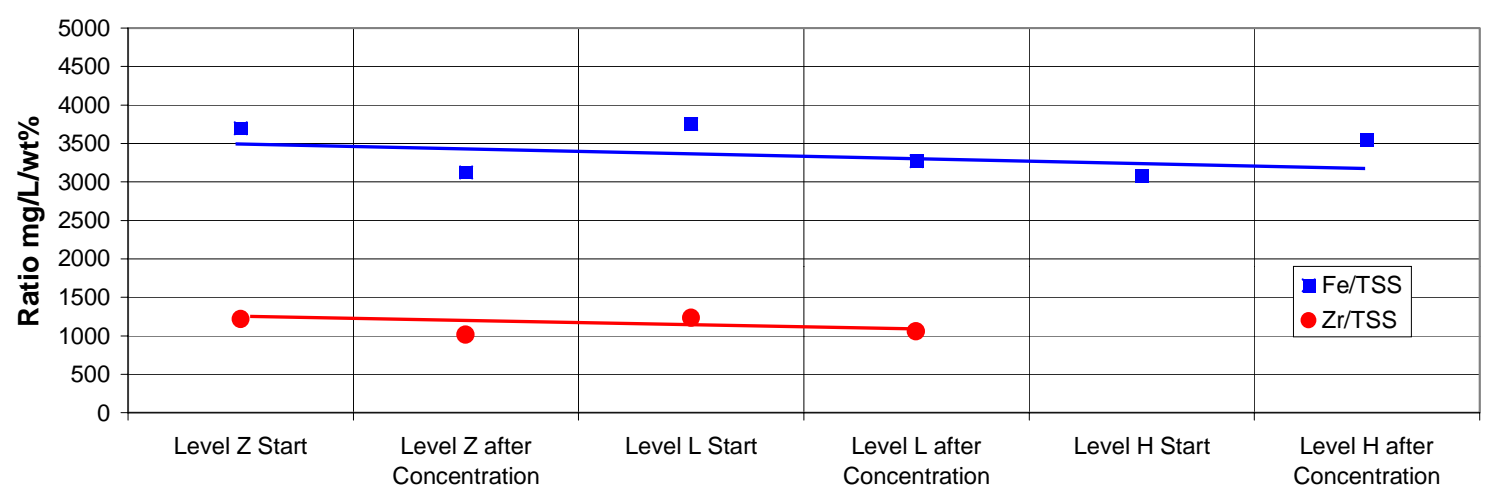

Figure 3.12 Ratio of Iron and Zirconium to Suspended Solids 

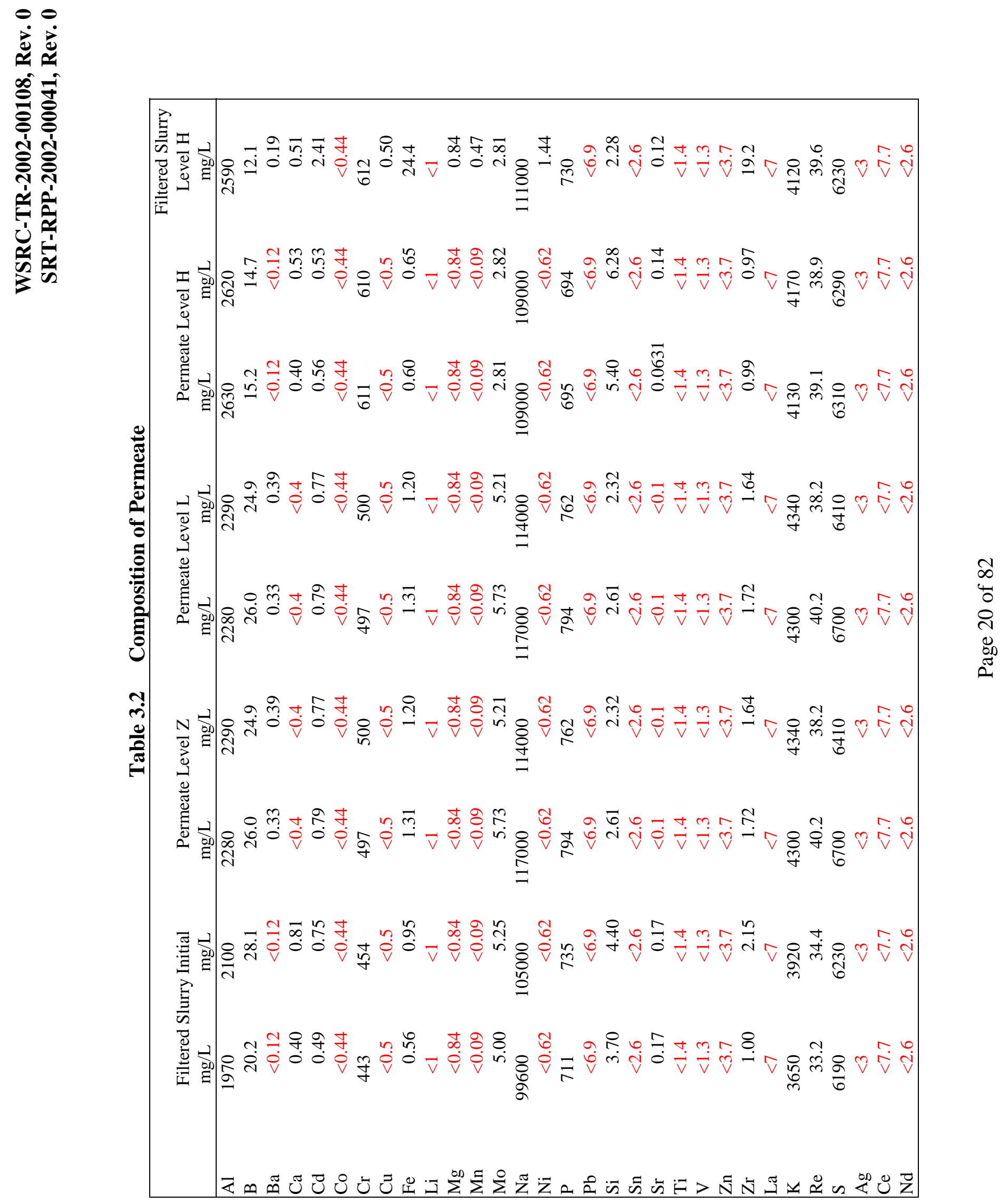


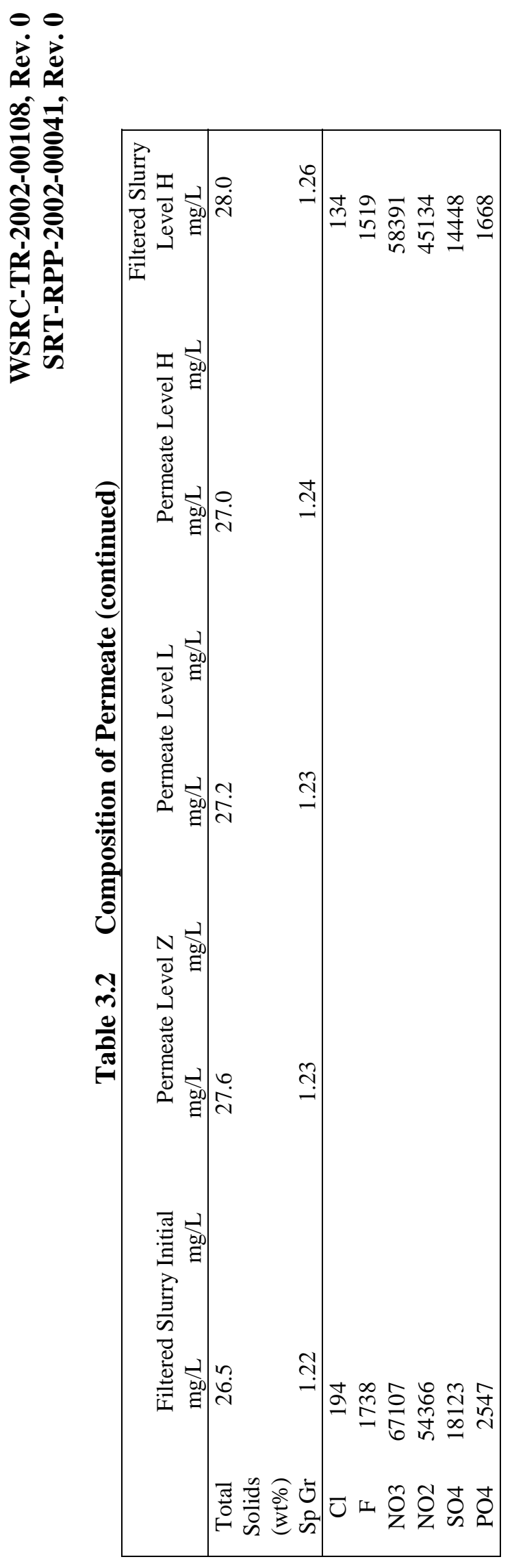

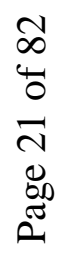




\subsection{Organics in Slurry and Permeate}

The concentrations of TBP and dodecane are plotted versus run number in Figure 3.15. As these organics were added during Level $\mathrm{M}$, the measured concentrations in the slurry were generally about $1 / 3$ of what the actual additions were.

The low measured concentration of organics would, at least initially, tend to indicate that the entire amount of organics did not pass through the filter system. If this were true, the filter would not have been challenged as much as planned. Visual observation of the top of the feed tank showed that, although the organic phase tended to float on top of the aqueous phase, it was periodically (on the order of several seconds) pulled down into the aqueous phase and fed to the filter. Figure 3.13 shows photos of slurry samples that show the presence of organics. No accumulation of organic phase above the liquid level, which would have been effectively excluded from processing, was seen. There also was no evidence of sticking elsewhere in the system.

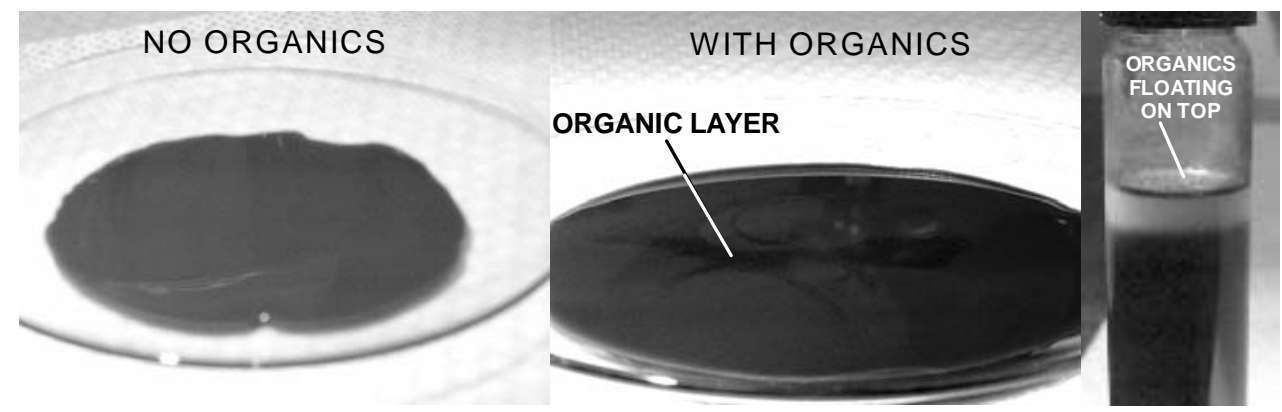

Figure 3.13 Photos of Slurry Samples

The lower than expected concentrations can be explained by the difficulty in getting a representative sample of the three phase (aqueous, solid, organic) mixture. Any given sample could contain different proportions of organics and slurry. The presence of organics in the samples taken from the piping at the pump inlet is verified by these analyses and also by visual examination of the samples. Figure 3.14 shows how the slurry samples were taken.

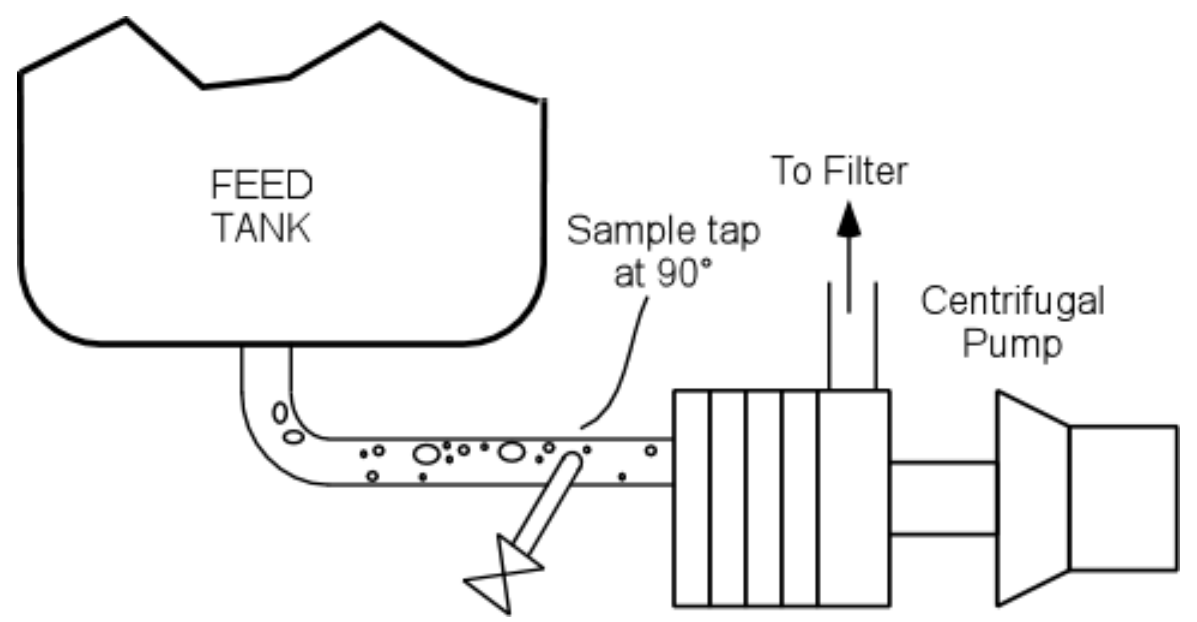

Figure 3.14 Possible Organic Phase Separation in Piping 
Due to the density difference, the organic phase will tend to float to top of pipe even in turbulent flow. The axial distribution of organic phase along the pipe will also be not uniform. Therefore, samples taken at the sample tap would be expected to have lower average organic concentration than the average material in the pipe. (However, this sample tap configuration should result in good samples for the slurry consisting of small particles.)

The permeate measurements show that the dodecane was always below the detection limit, which was approximately $0.12 \mathrm{mg} / \mathrm{L}$. The TBP concentrations in the permeate ranged from the detection limit of $0.12 \mathrm{mg} / \mathrm{L}$ to about $0.7 \mathrm{mg} / \mathrm{L}$. The approximate solubility of TBP in high $\mathrm{Na}^{+}$solutions is $1.1 \mathrm{mg} / \mathrm{L} .{ }^{9}$ The concentrations of dibutylphosphate and 1-butanol (nbutanol) were measured in two samples. A trace amount of 1-butanol was found in the permeate samples; the DBP was below the detection limit. Slurry sample results for DBP \& n-butanol were all below the detection limit. These data are summarized in Table 3.3.

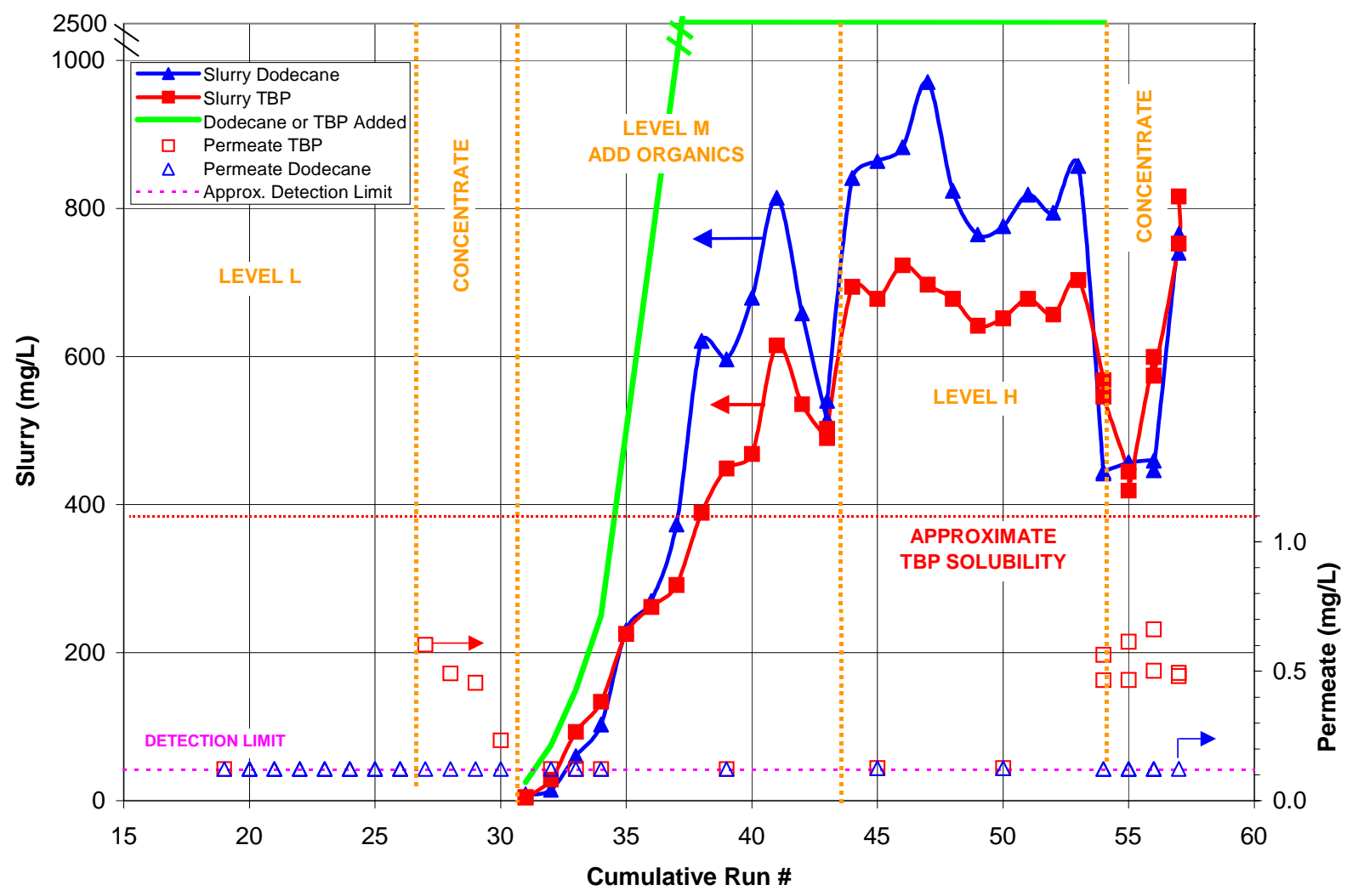

Figure 3.15 Organics Concentrations in Slurry and Permeate 


\section{Table 3.3 Dibutylphosphate and 1-Butanol in Samples}

\begin{tabular}{|l|c|c|}
\hline Sample & $\begin{array}{c}\text { dibutylphosphate } \\
\text { (DBP) } \\
\mathrm{mg} / \mathrm{L}\end{array}$ & $\begin{array}{c}\text { 1-butanol } \\
\text { (n-butanol) } \\
\mathrm{mg} / \mathrm{L}\end{array}$ \\
\hline $\begin{array}{l}\text { sludge (2 samples) } \\
\text { permeate }\end{array}$ & $<10$ & $<25$ \\
\hline permeate & $<10$ & 0.98 \\
\hline permeate & $<10$ & 2.0 \\
\hline
\end{tabular}

\subsection{Statistical Analysis of Data}

The filtrate flux for ultrafiltration can depend on several factors. To determine if the effects of TBP and NPH, transmembrane pressure, velocity, and run time (or approximately, number of runs) were significant, several potential models were examined. A number of models have been proposed for modeling the behavior of filters. Listed below are some of these models.

Kozeny-Carman $\mathrm{J} \propto \Delta \mathrm{P}$

Brownian Diffusion $\quad \mathrm{J} \propto \mathrm{V}^{0.503} \mathrm{C}^{\frac{1}{3}}$

Shear Induced Diffusion $\quad \mathrm{J} \propto \mathrm{V}^{1.75} \mathrm{C}^{\frac{1}{3}}$

$$
\text { Inertial Lift } \quad \mathrm{J} \propto \mathrm{V}^{3.5}
$$

Surface Transport $\quad \mathrm{J} \propto \mathrm{V}^{1.75}$

Lift Velocity $\mathrm{J} \propto \mathrm{V}^{2.625}$

Boundary Layer $\quad \mathrm{J} \propto \mathrm{V}^{1.75} \ln \left(\frac{1}{\mathrm{C}}\right)$ or $\mathrm{V}^{1.75}\left(\frac{1}{\mathrm{C}}\right)$

where $\mathbf{J}=$ transmembrane flux $\left(\mathrm{gpm} / \mathrm{ft}^{2}\right)$

$\mathrm{V}=\operatorname{velocity}(\mathrm{ft} / \mathrm{sec})$

$\Delta \mathrm{P}=$ transmembrane pressure $(\mathrm{psi})$

$\mathrm{C}=$ solids (insoluble) concentration $(\mathrm{wt} \%)$

In addition to the variables given above, the total organics concentration and total run time were added as variables to a generalized model that was proposed:

Generalized Model $\quad \mathrm{J}=\mathrm{aV}^{\mathrm{v}} \mathrm{C}^{\mathrm{c}} \Delta \mathrm{P}^{\mathrm{P}} \mathrm{Q}^{\mathrm{q}}\left(1-\mathrm{bt}_{\mathrm{adj}}\right)$

where $\quad \mathrm{Q}=$ organics concentration $+1(\mathrm{mg} / \mathrm{L})$

$\mathrm{t}_{\mathrm{adj}}=$ cumulative run time (hr) up to $13.5 \mathrm{hr}$, then $=13.5$ thereafter

$\mathrm{a}, \mathrm{v}, \mathrm{c}, \mathrm{p}, \mathrm{q}, \mathrm{b}=$ parameters (constants)

The cumulative run time term was added to account for the leveling off behavior shown in Figure 3.3. The linear drop occurs until about 13.5 hours, then the flux is essentially independent of time. The form of the organics concentration term was arbitrary since there was no theoretical basis for adding this term. The "concentration +1 " was used to make the baseline at zero organics have a contribution of " 1 " to the equation. The statistical analyses and curve fitting was performed using a statistical software package. ${ }^{10}$ 
WSRC-TR-2002-00108, Rev. 0

SRT-RPP-2002-00041, Rev. 0

The solids concentration term was immediately removed from the model because the solids concentration only varied from 2.95 to $3.53 \mathrm{wt} \%$, which is too small a range to reliably fit a model. (Actual fitting with this variable gave a stair-step predicted flux, as expect, which is not what was seen.) Fitting of the model without the effect of solids is summarized in Table 3.4 .

Table 3.4 Parameter Estimates for Model with Velocity, Adjusted Time, Pressure, and Organics Content

\begin{tabular}{|c|l|ll|}
\hline & & \multicolumn{2}{|c|}{$\begin{array}{c}\text { Approximate 95\% } \\
\text { Confidence Limit }\end{array}$} \\
\hline Parameter & Estimate & \multicolumn{1}{|c|}{ Lower } & Upper \\
\hline $\mathrm{a}$ & 0.002642 & 0.001728 & 0.004016 \\
$\mathrm{~V}$ & 1.350 & 1.234 & 1.467 \\
$b$ & 0.008222 & -0.004988 & 0.019929 \\
$q$ & -0.01972 & -0.03813 & 0.00058 \\
$p$ & -0.07914 & -0.15746 & 0.00129 \\
\hline
\end{tabular}

Correlation of Estimates

\begin{tabular}{|c|rrrrr|}
\hline & $\mathrm{a}$ & $\mathrm{v}$ & $\mathrm{b}$ & $\mathrm{q}$ & $\mathrm{p}$ \\
\hline $\mathrm{a}$ & 1.0000 & -0.7219 & 0.1902 & 0.1711 & -0.7145 \\
$\mathrm{v}$ & -0.7219 & 1.0000 & -0.1340 & -0.1209 & 0.0461 \\
$\mathrm{~b}$ & 0.1902 & -0.1340 & 1.0000 & $\mathbf{0 . 9 5 0 3}$ & -0.0074 \\
$\mathrm{q}$ & 0.1711 & -0.1209 & $\mathbf{0 . 9 5 0 3}$ & 1.0000 & -0.0244 \\
$\mathrm{p}$ & -0.7145 & 0.0461 & -0.0074 & -0.0244 & 1.0000 \\
\hline
\end{tabular}

The effect of pressure (p) is statistically insignificant since the confidence region includes zero. Both time "b" and organics "q" are also insignificant, although both parameters barely include zero. Moreover, they are highly correlated, so they tend to describe the same effect. Leaving out the effect of organics, since leaving this out makes more physical sense than leaving out time, gives the parameters in Table 3.5.

Table 3.5 Parameter Estimates for Model with Velocity and Adjusted Time

\begin{tabular}{|c|l|ll|}
\hline & & \multicolumn{2}{|c|}{$\begin{array}{c}\text { Approximate 95\% } \\
\text { Confidence Limit }\end{array}$} \\
\hline Parameter & Estimate & \multicolumn{1}{|c|}{ Lower } & Upper \\
\hline a & 0.002091 & 0.001543 & 0.002821 \\
v & 1.342 & 1.221 & 1.464 \\
b & 0.01942 & 0.01631 & 0.02233 \\
\hline
\end{tabular}

Correlation of Estimates

\begin{tabular}{|c|rrr|}
\hline & \multicolumn{1}{|c}{$\mathrm{a}$} & $\mathrm{v}$ & $\mathrm{b}$ \\
\hline $\mathrm{a}$ & 1.0000 & -0.9914 & 0.1717 \\
$\mathrm{~V}$ & -0.9914 & 1.0000 & -0.0597 \\
$\mathrm{~b}$ & 0.1717 & -0.0597 & 1.0000 \\
\hline
\end{tabular}


With only time as a variable, the parameter " $b$ " is significant. Parameters "a" and "v" are highly correlated as is common with exponential models. The best model is then:

$$
\mathrm{J}=0.002091 \mathrm{~V}^{1.342}\left(1-0.01942 \mathrm{t}_{\mathrm{adj}}\right)
$$

The predicted values for this model for all of the data is shown in Figure 3.16. The offset from each curve to the data points is due to the effect of pressure on flux. If a subset of the data is taken, the effect of pressure can be found to be statistically significant, but the scatter in the overall data hides this effect. In reality, higher pressures appear to result in slightly higher fluxes. Note the circled points in the Figure; if these are eliminated, the fit of the $V=11$ fps data is quite good.

Models with all parameters in most of the possible combinations were examined to thoroughly eliminate the possible models. Models without the time factor and with either the solids or organics gave statistically equivalent curve fits, but the shape of the curves were unrealistic. Figure 3.17 shows the fit of flux versus velocity, time, and organics concentration. Similar curves result from fitting versus velocity and just organics or solids. Figure 3.17 also shows that the adjusted time and organics concentration are highly correlated. A summary of the curve fits performed is given in Appendix 5.5.

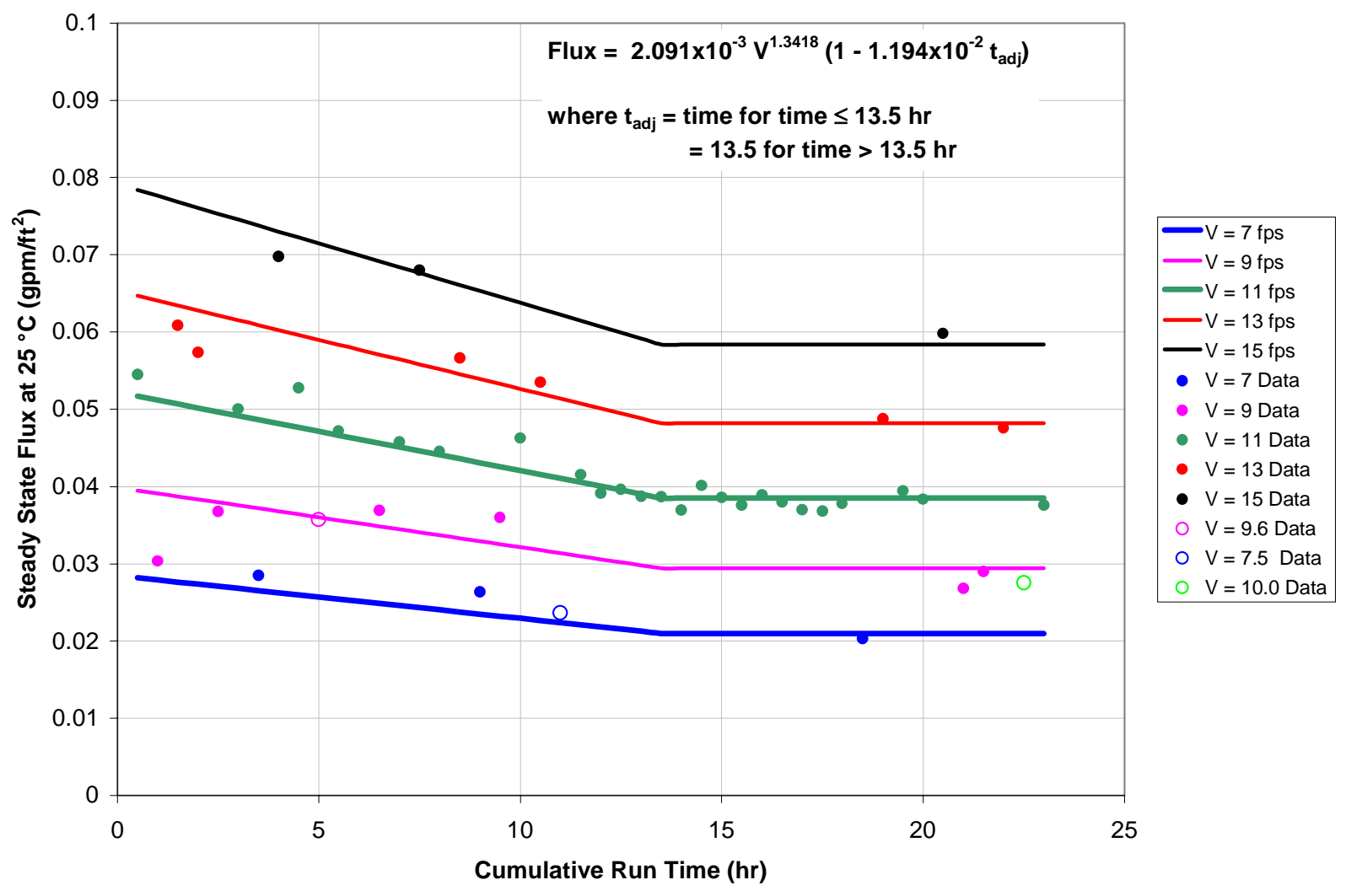

Figure 3.16 Fitted Data for Flux versus Velocity and Time 


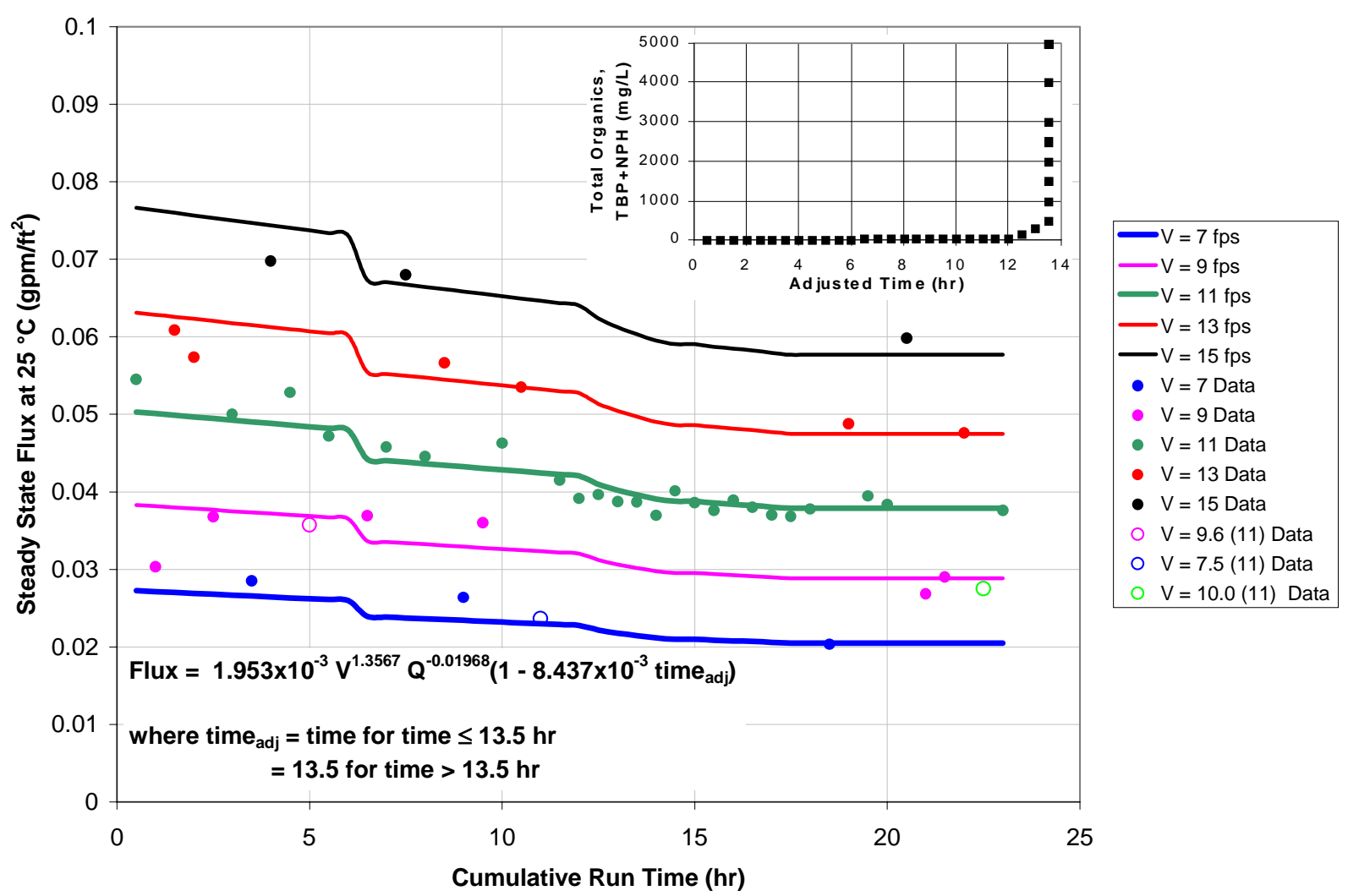

Figure 3.17 Fitted Data for Flux versus Velocity, Time, and Organics

\subsection{Quality Assurance}

This task was conducted per the requirements of a Task Technical \& Quality Assurance Plan that was approved by both SRTC and RPP-WTP personnel (technical \& QA manager). ${ }^{11}$ These tests were not HLW form affecting. Therefore, the Quality Assurance Requirements and Description (DOE/RW-0333P), the principle quality assurance requirements for the Civilian Radioactive Waste Management Program, did not apply to this work. All data was recorded in a Laboratory Notebook. ${ }^{12}$

\subsection{Conclusions}

1. The presence of tributyl phosphate and normal paraffin hydrocarbon (dodecane) at concentrations up to approximately $2500 \mathrm{mg} / \mathrm{L}$ of each has no effect on flux rate for filtration of an AZ-101 $3.5 \mathrm{wt} \%$ slurry simulant for a $0.1 \mu \mathrm{m}$ sintered metal Mott filter element.

2. If a concentration exists wherein the flux is affected (de minimis), it is above the tested levels.

3. The AZ-101 slurry simulant was filtered to an insoluble solids content of up to $6 \mathrm{wt} \%$ without the flux deteriorating below the lower limit of $0.014 \mathrm{gpm} / \mathrm{ft}^{2}$. 
WSRC-TR-2002-00108, Rev. 0

SRT-RPP-2002-00041, Rev. 0

4. The permeate concentration of TBP was always less than $1 \mathrm{mg} / \mathrm{L}$ and the dodecane was always less than the detection limit of $\sim 0.12 \mathrm{mg} / \mathrm{L}$. Neither of these passed through the filter at a level higher than its solubility and so were concentrated in the slurry.

5. Cleaning of the system after use with the organics proved difficult using only water and nitric acid. It should be noted that the concentrations of separable organics were much higher than should actually be seen in the WTP. We recommend that the effect of TBP and NPH be studied further during filter cleaning tests. 
WSRC-TR-2002-00108, Rev. 0

SRT-RPP-2002-00041, Rev. 0

\subsection{Appendices}

\subsection{Appendix - Supernate Recipe}

Volume of Feed Made from this Recipe

$8 \quad$ Liters

Weigh a LARGE MIXING VESSEL of

at least $8000 \quad \mathrm{ml}$ capacity

ADD THE FOLLOWING COMPOUNDS:

Transition Metals and Complexing Agents

Formula Mass Needed (g) Actual Wt (g)

\begin{tabular}{|c|c|c|c|}
\hline Alumimum Nitrate & $\mathrm{Al}(\mathrm{NO} 3) 3 \bullet 9 \mathrm{H} 2 \mathrm{O}$ & 1186.521 & 1186.52 \\
\hline Ammonium Nitrate & NH4NO3 & 11.759 & 11.76 \\
\hline Cesium Nitrate & CsNO3 & 0.438 & 0.438 \\
\hline Zirconyl Nitrate & $\mathrm{ZrO}(\mathrm{NO} 3) 2 \bullet x \mathrm{H} 2 \mathrm{O}$ & 0.067 & 0.067 \\
\hline Sodium Chloride & $\mathrm{NaCl}$ & 2.631 & 2.633 \\
\hline Sodium Fluoride & $\mathrm{NaF}$ & 32.06 & 32.064 \\
\hline Sodium Chromate & $\mathrm{Na} 2 \mathrm{CrO} 4$ & 18.189 & 18.1912 \\
\hline Sodium Sulfate & $\mathrm{Na} 2 \mathrm{SO} 4$ & 209.021 & 209.02 \\
\hline Sodium Perrhenate & $\mathrm{NaReO} 4$ & 0.468 & 0.4619 \\
\hline ADD & Formula & Mass Needed (g) & Actual Wt (g) \\
\hline Water & $\mathrm{H} 2 \mathrm{O}$ & 1600 & 1600.00 \\
\hline
\end{tabular}

MIX THOROUGHLY TO DISSOLVE THE SALTS.

IN A SEPARATE CONTAINER MIX THE FOLLOWING:

Formula Mass Needed (g) Actual Wt (g)

\begin{tabular}{|l|c|r|r|}
\hline Sodium Hydroxide & $\mathrm{NaOH}$ & 639.284 & 639.26 \\
\hline Potassium Hydroxide & $\mathrm{KOH}$ & 53.085 & 53.09 \\
\hline Water & $\mathrm{H} 2 \mathrm{O}$ & 800 & 800.00 \\
\hline
\end{tabular}

MIX THOROUGHLY TO DISSOLVE THE SODIUM HYDROXIDE AND POTASSIUM HYDROXIDE.

ADD Mass Needed (g) Actual Wt (g)

\begin{tabular}{|l|c|r|r|}
\hline Sodium Phosphate & Na3PO4•12H2O & 48.117 & 48.12 \\
\hline Water & H2O & 1600 & 1600.00 \\
\hline
\end{tabular}

MIX THOROUGHLY. THEN ADD THIS SOLUTION SLOWLY TO THE MIXING VESSEL WHILE MAINTAINING AGITATION.

ADD

Formula Mass Needed (g) Actual Wt (g)

Sodium Carbonate

\begin{tabular}{|l|l|l|}
$\mathrm{Na} 2 \mathrm{CO} 3$ & 326.057 & 326.06 \\
\hline
\end{tabular}

MIX THOROUGHLY.

ADD Formula Mass Needed (g) Actual Wt (g)

\begin{tabular}{|c|c|c|c|}
\hline Sodium Nitrate & $\mathrm{NaNO} 3$ & 10.162 & 10.16 \\
\hline Sodium Nitrite & $\mathrm{NaNO} 2$ & 780.663 & 780.66 \\
\hline \multicolumn{4}{|l|}{ MIX THOROUGHLY. } \\
\hline NEXT ADD THE FINAL WATER ADDITION & Formula & Mass Needed (g) & Actual Wt $(\mathrm{g})$ \\
\hline Water & $\mathrm{H} 2 \mathrm{O}$ & 2371.31 & 2371.30 \\
\hline
\end{tabular}




\subsection{Appendix - Simulant Compositions}

The final simulant was made up from 4.0 liters of supernate simulant, 1.84 liters of solids simulant \#1 and 0.25 liters of solids simulant \#3. Trim chemicals, in amounts shown below, were then added to replace the washed sodium and anions. The final volume was approximately 6.3 liters.

Table 5.1 Supernate Simulant Samples

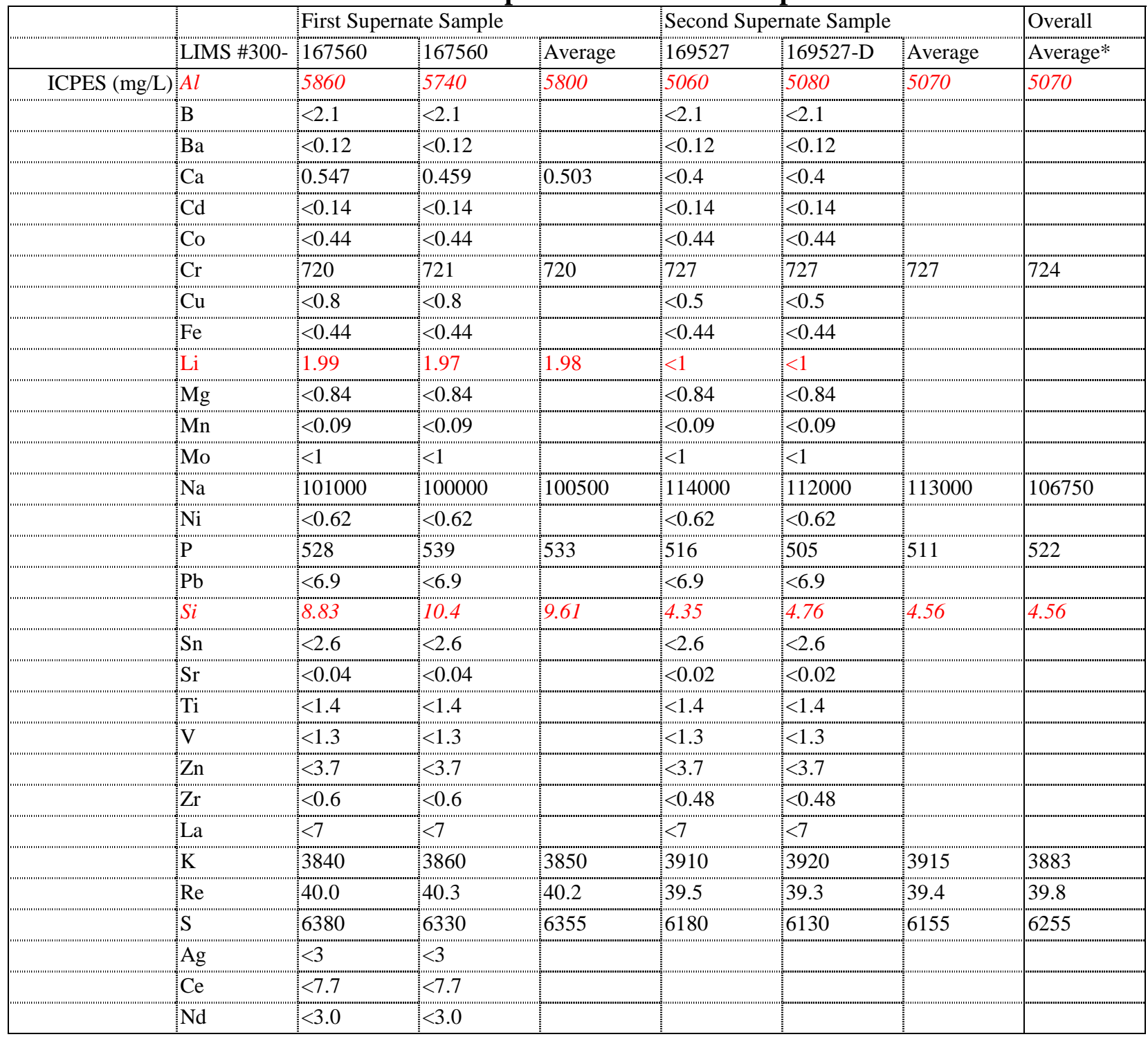


WSRC-TR-2002-00108, Rev. 0

SRT-RPP-2002-00041, Rev. 0

\section{Supernate Simulant Samples (continued)}

\begin{tabular}{|c|c|c|c|c|c|c|c|c|}
\hline & & \multicolumn{3}{|c|}{ First Supernate Sample } & \multicolumn{3}{|c|}{ Second Supernate Sample } & \multirow{2}{*}{$\begin{array}{l}\text { Overall } \\
\text { Average* }\end{array}$} \\
\hline & LIMS \#300- & 167560 & 167560 & Average & 169527 & $169527-D$ & Average & \\
\hline \multirow[t]{8}{*}{$\mathrm{IC}(\mathrm{mg} / \mathrm{L})$} & $\mathrm{F}$ & 1570 & 1574 & 1572 & NA & NA & 1572 & 1572 \\
\hline & formate & $<100$ & $<100$ & $<100$ & NA & NA & & \\
\hline & $\mathrm{Cl}$ & 139 & 141 & 140 & NA & NA & 140 & 140 \\
\hline & NO2- & 60805 & 61724 & 61265 & NA & NA & 61265 & 61265 \\
\hline & NO3- & 61724 & 62704 & 62214 & NA & NA & 62214 & 62214 \\
\hline & PO4 $(-3)$ & 1292 & 1385 & 1339 & NA & NA & 1339 & 1339 \\
\hline & $\mathrm{SO} 4(-2)$ & 21402 & 21385 & 21394 & NA & NA & 21394 & 21394 \\
\hline & oxalate & $<100$ & $<101$ & & NA & NA & 0 & \\
\hline \multirow{4}{*}{ Carbon (mg/L) } & TOC & 4.60 & 4.60 & 4.60 & NA & NA & 4.60 & 4.60 \\
\hline & ITIC & $<1$ & $<1$ & $<1$ & NA & NA & $<1$ & \\
\hline & TC & 5.03 & 5.03 & 5.03 & NA & NA & 5.03 & 5.03 \\
\hline & Free OH & $\mathrm{NA}$ & NA & $\mathrm{NA}$ & NA & NA & $\mathrm{NA}$ & \\
\hline Solids & Total & 27.5 & 27.6 & 27.5 & NA & NA & 27.5 & 27.5 \\
\hline Specific & Gravity & 1.244 & 1.241 & 1.243 & NA & NA & 1.243 & 1.24 \\
\hline Estimated & $\mathrm{Sp} \mathrm{Gr}$ & 1.198 & 1.200 & & & & & \\
\hline
\end{tabular}

* Average for Al, Li, Si from second sample only due to drop (precipitation).

Values < detection limit not shown in averages. 
WSRC-TR-2002-00108, Rev. 0

SRT-RPP-2002-00041, Rev. 0

Table 5.2 Sludge Solids Sample \#1: Composition of solids filtered from sample.

\begin{tabular}{|c|c|c|c|c|}
\hline & LIMS \#300- & 167562 & 167564 & Mean \\
\hline \multirow[t]{31}{*}{ ICPES (mg/kg) } & $\mathrm{Ag}$ & 351 & 349 & 350 \\
\hline & $\mathrm{Al}$ & 791 & 799 & 795 \\
\hline & $\mathrm{B}$ & NA & NA & NA \\
\hline & $\mathrm{Ba}$ & 257 & 254 & 255 \\
\hline & $\mathrm{Ca}$ & 669 & 737 & 703 \\
\hline & $\mathrm{Cd}$ & 3210 & 3160 & 3185 \\
\hline & $\mathrm{Ce}$ & 341 & 306 & 323 \\
\hline & $\mathrm{Co}$ & 415 & 413 & 414 \\
\hline & $\mathrm{Cr}$ & 329 & 327 & 328 \\
\hline & $\mathrm{Cu}$ & 139 & 144 & 141 \\
\hline & $\mathrm{Fe}$ & 41700 & 40900 & 41300 \\
\hline & $\mathrm{K}$ & 673 & 759 & 716 \\
\hline & $\mathrm{La}$ & 1610 & 1580 & 1595 \\
\hline & $\mathrm{Li}$ & $<10$ & $<10$ & \\
\hline & $\mathrm{Mg}$ & 63.1 & 62.8 & 63.0 \\
\hline & Mn & 989 & 981 & 985 \\
\hline & Mo & $<20$ & $<20$ & \\
\hline & $\mathrm{Na}$ & 8000 & 8090 & 8045 \\
\hline & $\mathrm{Nd}$ & 1110 & 1080 & 1095 \\
\hline & $\mathrm{Ni}$ & 2520 & 2490 & 2505 \\
\hline & $\mathrm{P}$ & 1130 & 1050 & 1090 \\
\hline & $\mathrm{Pb}$ & 486 & 475 & 480 \\
\hline & $\mathrm{Re}$ & 17.4 & 18.6 & 18.0 \\
\hline & $\mathrm{S}$ & 335 & 347 & 341 \\
\hline & $\mathrm{Si}$ & 2680 & 4090 & 3385 \\
\hline & $\mathrm{Sn}$ & $<50$ & $<50$ & \\
\hline & $\mathrm{Sr}$ & 122 & 120 & 121 \\
\hline & $\mathrm{Ti}$ & 78.8 & 75.7 & 77.3 \\
\hline & $\mathrm{V}$ & $<15$ & $<15$ & \\
\hline & $\mathrm{Zn}$ & 140 & 139 & 140 \\
\hline & $\mathrm{Zr}$ & 13400 & 13300 & 13350 \\
\hline \multicolumn{5}{|c|}{ Original Sample (prior to filtration) } \\
\hline \multirow[t]{3}{*}{ Solids } & Total & 14.9 & 14.8 & 14.8 \\
\hline & Insoluble & 13.7 & 13.1 & 13.4 \\
\hline & e (calculated) & 1.18 & 1.61 & 1.40 \\
\hline
\end{tabular}


WSRC-TR-2002-00108, Rev. 0

SRT-RPP-2002-00041, Rev. 0

Table 5.3 Sludge Solids Sample \#2: Composition of solids filtered from sample.

\begin{tabular}{|c|c|c|c|c|}
\hline & LIMS \#300- & 167566 & 167568 & Mean \\
\hline \multirow{31}{*}{ ICPES (mg/kg) } & $\mathrm{Ag}$ & 186 & 182 & 184 \\
\hline & $\mathrm{Al}$ & 400 & 385 & 393 \\
\hline & B & NA & NA & NA \\
\hline & $\mathrm{Ba}$ & 135 & 133 & 134 \\
\hline & $\mathrm{Ca}$ & 777 & 771 & 774 \\
\hline & $\mathrm{Cd}$ & 1680 & 1650 & 1665 \\
\hline & $\mathrm{Ce}$ & 176 & 180 & 178 \\
\hline & Co & 221 & 217 & 219 \\
\hline & $\mathrm{Cr}$ & 176 & 171 & 174 \\
\hline & $\mathrm{Cu}$ & 73.2 & 74.4 & 73.8 \\
\hline & $\mathrm{Fe}$ & 21900 & 21800 & 21850 \\
\hline & $\mathrm{K}$ & 395 & 433 & 414 \\
\hline & $\mathrm{La}$ & 848 & 854 & 851 \\
\hline & $\mathrm{Li}$ & $<10$ & $<10$ & NA \\
\hline & $\mathrm{Mg}$ & 42.2 & 36.8 & 39.5 \\
\hline & $\mathrm{Mn}$ & 523 & 520 & 521 \\
\hline & Mo & $<20$ & $<20$ & NA \\
\hline & $\mathrm{Na}$ & 3950 & 3890 & 3920 \\
\hline & $\mathrm{Nd}$ & 555 & 537 & 546 \\
\hline & $\mathrm{Ni}$ & 1320 & 1290 & 1305 \\
\hline & $\mathrm{P}$ & 316 & 234 & 275 \\
\hline & $\mathrm{Pb}$ & 270 & 253 & 262 \\
\hline & $\operatorname{Re}$ & 7.91 & 6.30 & 7.10 \\
\hline & $\mathrm{S}$ & 173 & 153 & 163 \\
\hline & $\mathrm{Si}$ & 3240 & 3290 & 3265 \\
\hline & Sn & $<50$ & $<50$ & NA \\
\hline & $\mathrm{Sr}$ & 64.0 & 64.0 & 64.0 \\
\hline & $\mathrm{Ti}$ & 42.3 & 39.7 & 41.0 \\
\hline & V & $<15$ & $<15$ & NA \\
\hline & $\mathrm{Zn}$ & 73.7 & 72.3 & 73.0 \\
\hline & $\mathrm{Zr}$ & 6970 & 6930 & 6950 \\
\hline \multicolumn{5}{|c|}{ Original Sample (prior to filtration) } \\
\hline \multirow[t]{3}{*}{ Solids } & Total & 8.05 & 8.00 & 8.03 \\
\hline & Insoluble & 7.25 & 7.19 & 7.22 \\
\hline & le (calculated) & 0.80 & 0.81 & 0.81 \\
\hline
\end{tabular}


WSRC-TR-2002-00108, Rev. 0

SRT-RPP-2002-00041, Rev. 0

Table 5.4 Sludge Solids Sample \#3: Composition of solids filtered from sample.

\begin{tabular}{|c|c|c|c|c|}
\hline & LIMS \#300- & $169717 \mathrm{a}$ & $169717 \mathrm{~b}$ & Calculated \\
\hline \multirow[t]{31}{*}{ ICPES (mg/kg) } & $\mathrm{Ag}$ & & & 263 \\
\hline & $\mathrm{Al}$ & & & 597 \\
\hline & B & & & \\
\hline & $\mathrm{Ba}$ & & & 192 \\
\hline & $\mathrm{Ca}$ & & & 528 \\
\hline & $\mathrm{Cd}$ & & & 2392 \\
\hline & $\mathrm{Ce}$ & & & 243 \\
\hline & Co & & & 311 \\
\hline & $\mathrm{Cr}$ & \multirow{3}{*}{\multicolumn{2}{|c|}{$\begin{array}{l}\text { Composition same as } \\
\text { Sample \#2, but more } \\
\text { concentrated. }\end{array}$}} & 246 \\
\hline & $\mathrm{Cu}$ & & & 106 \\
\hline & $\mathrm{Fe}$ & & & 31017 \\
\hline & $\mathrm{K}$ & & & 538 \\
\hline & $\mathrm{La}$ & & & 1198 \\
\hline & $\mathrm{Li}$ & & & \\
\hline & $\mathrm{Mg}$ & \multirow{3}{*}{\multicolumn{2}{|c|}{$\begin{array}{l}\text { Calculated composition } \\
\text { based on ratioing total } \\
\text { solids. }\end{array}$}} & 47.3 \\
\hline & $\mathrm{Mn}$ & & & 740 \\
\hline & Mo & & & \\
\hline & $\mathrm{Na}$ & & & 6042 \\
\hline & $\mathrm{Nd}$ & & & 822 \\
\hline & $\mathrm{Ni}$ & & & 1881 \\
\hline & $\mathrm{P}$ & & & 819 \\
\hline & $\mathrm{Pb}$ & & & 361 \\
\hline & $\mathrm{Re}$ & & & 13.5 \\
\hline & $\mathrm{S}$ & & & 256 \\
\hline & $\mathrm{Si}$ & & & 2542 \\
\hline & $\mathrm{Sn}$ & & & \\
\hline & $\mathrm{Sr}$ & & & 91.2 \\
\hline & $\mathrm{Ti}$ & & & 58.0 \\
\hline & V & & & \\
\hline & $\mathrm{Zn}$ & & & 105 \\
\hline & $\mathrm{Zr}$ & & & 10026 \\
\hline \multicolumn{5}{|c|}{ Original Sample (prior to filtration) } \\
\hline \multirow[t]{3}{*}{ Solids (wt\%) } & Total & 11.2 & 11.1 & 11.1 \\
\hline & Insoluble & 9.97 & 9.73 & 9.85 \\
\hline & le (calculated) & 1.21 & 1.32 & 1.27 \\
\hline
\end{tabular}


WSRC-TR-2002-00108, Rev. 0

SRT-RPP-2002-00041, Rev. 0

Table 5.5 Sludge Sample \#1: Composition of filtrate from sample.

\begin{tabular}{|c|c|c|c|c|}
\hline & LIMS \#300- & $\begin{array}{l}167561 \\
\mathrm{mg} / \mathrm{L}\end{array}$ & $\begin{array}{l}167563 \\
\mathrm{mg} / \mathrm{L}\end{array}$ & $\begin{array}{l}\text { Average } \\
\mathrm{mg} / \mathrm{L}\end{array}$ \\
\hline \multirow[t]{31}{*}{ ICPES } & $\mathrm{Ag}$ & $<3$ & $<3$ & $<3$ \\
\hline & $\mathrm{Al}$ & 5.08 & $<2.4$ & 5.08 \\
\hline & B & 16.4 & 26.9 & 21.6 \\
\hline & $\mathrm{Ba}$ & $<0.12$ & $<0.12$ & $<0.12$ \\
\hline & $\mathrm{Ca}$ & 15.2 & 11.9 & 13.6 \\
\hline & $\mathrm{Cd}$ & $<0.14$ & $<0.14$ & $<0.14$ \\
\hline & $\mathrm{Ce}$ & $<7.7$ & $<7.7$ & $<7.7$ \\
\hline & Co & $<0.44$ & $<0.44$ & $<0.44$ \\
\hline & $\mathrm{Cr}$ & 4.52 & 6.66 & 5.59 \\
\hline & $\mathrm{Cu}$ & $<0.6$ & $<0.6$ & $<0.6$ \\
\hline & $\mathrm{Fe}$ & $<0.44$ & $<0.44$ & $<0.44$ \\
\hline & $\mathrm{K}$ & 313 & 444 & 378 \\
\hline & $\mathrm{La}$ & $<7$ & $<7$ & $<7$ \\
\hline & $\mathrm{Li}$ & NA & NA & NA \\
\hline & $\mathrm{Mg}$ & 3.71 & 3.98 & 3.84 \\
\hline & $\mathrm{Mn}$ & $<0.09$ & $<0.09$ & $<0.09$ \\
\hline & Mo & 9.83 & 15.4 & 12.6 \\
\hline & $\mathrm{Na}$ & 4190 & 6150 & 5170 \\
\hline & $\mathrm{Nd}$ & $<2.6$ & $<2.6$ & $<2.6$ \\
\hline & $\mathrm{Ni}$ & $<0.62$ & $<0.62$ & $<0.62$ \\
\hline & $\mathrm{P}$ & $<6.8$ & $<6.8$ & $<6.8$ \\
\hline & $\mathrm{Pb}$ & $<6.9$ & $<6.9$ & $<6.9$ \\
\hline & $\operatorname{Re}$ & 12.0 & 18.0 & 15.0 \\
\hline & $\mathrm{S}$ & 254 & 363 & 308 \\
\hline & $\mathrm{Si}$ & $<1.3$ & $<1.3$ & $<1.3$ \\
\hline & Sn & NA & NA & NA \\
\hline & $\mathrm{Sr}$ & $<0.15$ & $<0.15$ & $<0.15$ \\
\hline & $\mathrm{Ti}$ & $<1.4$ & $<1.4$ & $<1.4$ \\
\hline & V & NA & NA & NA \\
\hline & $\mathrm{Zn}$ & $<3.7$ & $<3.7$ & $<3.7$ \\
\hline & $\mathrm{Zr}$ & $<0.48$ & $<0.48$ & $<0.48$ \\
\hline \multirow[t]{8}{*}{ IC } & fluoride & 47.0 & 69.0 & 58.0 \\
\hline & formate & $<100$ & $<100$ & $<100$ \\
\hline & chloride & 85.0 & 108 & 96.5 \\
\hline & nitrite & 2916 & 4166 & 3541 \\
\hline & nitrate & 2655 & 3916 & 3286 \\
\hline & phosphate & $<100$ & $<100$ & $<100$ \\
\hline & sulfate & 572 & 837 & 705 \\
\hline & oxalate & $<100$ & $<100$ & $<100$ \\
\hline
\end{tabular}


Table 5.6 Sludge Sample \#2: Composition of filtrate from sample.

\begin{tabular}{|c|c|c|c|c|}
\hline & LIMS \#300- & $\begin{array}{l}167565 \\
\mathrm{mg} / \mathrm{L}\end{array}$ & $\begin{array}{l}167567 \\
\mathrm{mg} / \mathrm{L}\end{array}$ & $\begin{array}{l}\text { Average } \\
\mathrm{mg} / \mathrm{L}\end{array}$ \\
\hline \multirow[t]{31}{*}{ ICPES } & $\mathrm{Ag}$ & $<3$ & $<3$ & $<3$ \\
\hline & $\mathrm{Al}$ & $<2.4$ & $<2.4$ & $<2.4$ \\
\hline & B & 15.0 & 14.8 & 14.9 \\
\hline & $\mathrm{Ba}$ & $<0.12$ & $<0.12$ & $<0.12$ \\
\hline & $\mathrm{Ca}$ & 8.90 & 10.1 & 9.52 \\
\hline & $\mathrm{Cd}$ & $<0.14$ & $<0.14$ & $<0.14$ \\
\hline & $\mathrm{Ce}$ & $<7.7$ & $<7.7$ & $<7.7$ \\
\hline & Co & $<0.44$ & $<0.44$ & $<0.44$ \\
\hline & $\mathrm{Cr}$ & 2.98 & 3.00 & 2.99 \\
\hline & $\mathrm{Cu}$ & $<0.6$ & $<0.6$ & $<0.6$ \\
\hline & $\mathrm{Fe}$ & $<0.44$ & $<0.44$ & $<0.44$ \\
\hline & $\mathrm{K}$ & 216 & 227 & 222 \\
\hline & $\mathrm{La}$ & $<7$ & $<7$ & $<7$ \\
\hline & $\mathrm{Li}$ & NA & NA & NA \\
\hline & $\mathrm{Mg}$ & 1.59 & 2.03 & 1.81 \\
\hline & $\mathrm{Mn}$ & $<0.09$ & $<0.09$ & $<0.09$ \\
\hline & Mo & 6.90 & 6.48 & 6.69 \\
\hline & $\mathrm{Na}$ & 2910 & 2790 & 2850 \\
\hline & $\mathrm{Nd}$ & $<2.6$ & $<2.6$ & $<2.6$ \\
\hline & $\mathrm{Ni}$ & $<0.62$ & $<0.62$ & $<0.62$ \\
\hline & $\mathrm{P}$ & $<6.8$ & $<6.8$ & $<6.8$ \\
\hline & $\mathrm{Pb}$ & $<6.9$ & $<6.9$ & $<6.9$ \\
\hline & $\mathrm{Re}$ & 7.81 & 7.78 & 7.79 \\
\hline & $\mathrm{S}$ & 160 & 162 & 161 \\
\hline & $\mathrm{Si}$ & $<1.3$ & $<1.3$ & $<1.3$ \\
\hline & Sn & NA & NA & NA \\
\hline & $\mathrm{Sr}$ & $<0.15$ & $<0.15$ & $<0.15$ \\
\hline & $\mathrm{Ti}$ & $<1.4$ & $<1.4$ & $<1.4$ \\
\hline & V & NA & NA & NA \\
\hline & $\mathrm{Zn}$ & $<3.7$ & $<3.7$ & $<3.7$ \\
\hline & $\mathrm{Zr}$ & $<0.48$ & $<0.48$ & $<0.48$ \\
\hline \multirow[t]{8}{*}{ IC } & fluoride & 38.0 & 37.0 & 37.5 \\
\hline & formate & $<100$ & $<100$ & $<100$ \\
\hline & chloride & 69.0 & 67.0 & 68.0 \\
\hline & nitrite & 1871 & 1833 & 1852 \\
\hline & nitrate & 1627 & 1595 & 1611 \\
\hline & phosphate & $<100$ & $<100$ & $<100$ \\
\hline & sulfate & 382 & 378 & 380 \\
\hline & oxalate & $<100$ & $<100$ & $<100$ \\
\hline
\end{tabular}


WSRC-TR-2002-00108, Rev. 0

SRT-RPP-2002-00041, Rev. 0

Table 5.7 Sludge Sample \#3: Composition of filtrate calculated from composition of Sample \#2 by ratio.

\begin{tabular}{|c|c|}
\hline & Calculated $(\mathrm{mg} / \mathrm{L})$ \\
\hline $\mathrm{Ag}$ & 0 \\
\hline $\mathrm{Al}$ & 4.42 \\
\hline B & 18.9 \\
\hline $\mathrm{Ba}$ & 0 \\
\hline $\mathrm{Ca}$ & 11.8 \\
\hline $\mathrm{Cd}$ & 0 \\
\hline $\mathrm{Ce}$ & 0 \\
\hline Co & 0 \\
\hline $\mathrm{Cr}$ & 4.87 \\
\hline $\mathrm{Cu}$ & 0 \\
\hline $\mathrm{Fe}$ & 0 \\
\hline $\mathrm{K}$ & 330 \\
\hline $\mathrm{La}$ & 0 \\
\hline $\mathrm{Li}$ & 0 \\
\hline $\mathrm{Mg}$ & 3.35 \\
\hline $\mathrm{Mn}$ & 0 \\
\hline Mo & 11.0 \\
\hline $\mathrm{Na}$ & 4506 \\
\hline $\mathrm{Nd}$ & 0 \\
\hline $\mathrm{Ni}$ & 0 \\
\hline $\mathrm{P}$ & 0 \\
\hline $\mathrm{Pb}$ & 0 \\
\hline $\mathrm{Re}$ & 13.1 \\
\hline $\mathrm{S}$ & 269 \\
\hline $\mathrm{Si}$ & 0 \\
\hline $\mathrm{Sn}$ & 0 \\
\hline $\mathrm{Sr}$ & 0 \\
\hline $\mathrm{Ti}$ & 0 \\
\hline V & 0 \\
\hline $\mathrm{Zn}$ & 0 \\
\hline $\mathrm{Zr}$ & 0 \\
\hline fluoride & 50.5 \\
\hline formate & 0 \\
\hline chloride & 84.1 \\
\hline nitrite & 3086 \\
\hline nitrate & 2863 \\
\hline phosphate & 0 \\
\hline sulfate & 614 \\
\hline oxalate & 0 \\
\hline
\end{tabular}


WSRC-TR-2002-00108, Rev. 0

SRT-RPP-2002-00041, Rev. 0

Table 5.8 Overall Compositions of Samples \#1-3 Calculated from Solids and Filtrate Analyses.

\begin{tabular}{|c|c|c|c|c|}
\hline & & $\begin{array}{c}\text { Sample \#1 } \\
\mathrm{mg} / \mathrm{L}\end{array}$ & $\begin{array}{c}\text { Sample \#2 } \\
\mathrm{mg} / \mathrm{L}\end{array}$ & $\begin{array}{c}\text { Sample \#3 } \\
\mathrm{mg} / \mathrm{L}\end{array}$ \\
\hline \multirow[t]{31}{*}{ Metals } & $\mathrm{Ag}$ & 345 & 172 & 247 \\
\hline & $\mathrm{Al}$ & 788 & 368 & 565 \\
\hline & B & 20.3 & 14.4 & 18.0 \\
\hline & $\mathrm{Ba}$ & 252 & 125 & 180 \\
\hline & $\mathrm{Ca}$ & 705 & 734 & 508 \\
\hline & $\mathrm{Cd}$ & 3137 & 1559 & 2249 \\
\hline & $\mathrm{Ce}$ & 319 & 166 & 228 \\
\hline & Co & 408 & 205 & 292 \\
\hline & $\mathrm{Cr}$ & 328 & 165 & 236 \\
\hline & $\mathrm{Cu}$ & 139 & 69.1 & 99.9 \\
\hline & $\mathrm{Fe}$ & 40681 & 20462 & 29166 \\
\hline & $\mathrm{K}$ & 1060 & 601 & 820 \\
\hline & $\mathrm{La}$ & 1571 & 797 & 1126 \\
\hline & $\mathrm{Li}$ & 0 & 0 & 0 \\
\hline & $\mathrm{Mg}$ & 65.6 & 38.8 & 47.7 \\
\hline & $\mathrm{Mn}$ & 970 & 488 & 696 \\
\hline & Mo & 11.8 & 6.45 & 10.5 \\
\hline & $\mathrm{Na}$ & 12770 & 6420 & 9975 \\
\hline & $\mathrm{Nd}$ & 1079 & 511 & 773 \\
\hline & $\mathrm{Ni}$ & 2467 & 1222 & 1769 \\
\hline & $\mathrm{P}$ & 1074 & 258 & 770 \\
\hline & $\mathrm{Pb}$ & 473 & 245 & 339 \\
\hline & $\mathrm{Re}$ & 31.8 & 14.2 & 25.2 \\
\hline & $\mathrm{S}$ & 625 & 308 & 497 \\
\hline & $\mathrm{Si}$ & 3334 & 3058 & 2390 \\
\hline & $\mathrm{Sn}$ & 0 & 0 & 0 \\
\hline & $\mathrm{Sr}$ & 120 & 59.9 & 85.7 \\
\hline & $\mathrm{Ti}$ & 76.1 & 38.4 & 54.6 \\
\hline & $\mathrm{V}$ & 0 & 0 & 0 \\
\hline & $\mathrm{Zn}$ & 138 & 68.4 & 98.6 \\
\hline & $\mathrm{Zr}$ & 13150 & 6509 & 9428 \\
\hline \multirow[t]{8}{*}{ Anions } & fluoride & 54.4 & 36.2 & 48.2 \\
\hline & formate & 0 & 0 & 0 \\
\hline & chloride & 90.4 & 65.6 & 80.1 \\
\hline & nitrite & 3318 & 1786 & 2941 \\
\hline & nitrate & 3079 & 1554 & 2728 \\
\hline & phosphate & 0 & 0 & 0 \\
\hline & sulfate & 660 & 367 & 585 \\
\hline & oxalate & 0 & 0 & 0 \\
\hline \multirow[t]{4}{*}{ Solids (wt\%) } & Insoluble & 13.4 & 7.22 & 9.85 \\
\hline & Soluble & 1.40 & 0.805 & 1.27 \\
\hline & Total & 14.8 & 8.03 & 11.1 \\
\hline & Specific gravity & 1.09 & 1.04 & 1.06 \\
\hline
\end{tabular}


WSRC-TR-2002-00108, Rev. 0

SRT-RPP-2002-00041, Rev. 0

\section{Table 5.9 Trim Chemicals Added}

\begin{tabular}{|lc|}
\hline Chemical & Amount $(\mathrm{g})$ \\
\hline $\mathrm{NaOH}$ & 141.01 \\
$\mathrm{NaCl}$ & 0.25 \\
$\mathrm{NaF}$ & 7.79 \\
$\mathrm{NaNO}_{2}$ & 204.04 \\
$\mathrm{NaNO}_{3}$ & 190.06 \\
$\mathrm{Na}_{3} \mathrm{PO}_{4} * 12 \mathrm{H}_{2} \mathrm{O}$ & 12.45 \\
$\mathrm{Na}_{2} \mathrm{SO}_{4}$ & 71.60 \\
$\mathrm{KNO}_{3}$ & 18.14 \\
$\mathrm{NaReO}_{4}$ & 0.0548 \\
\hline
\end{tabular}



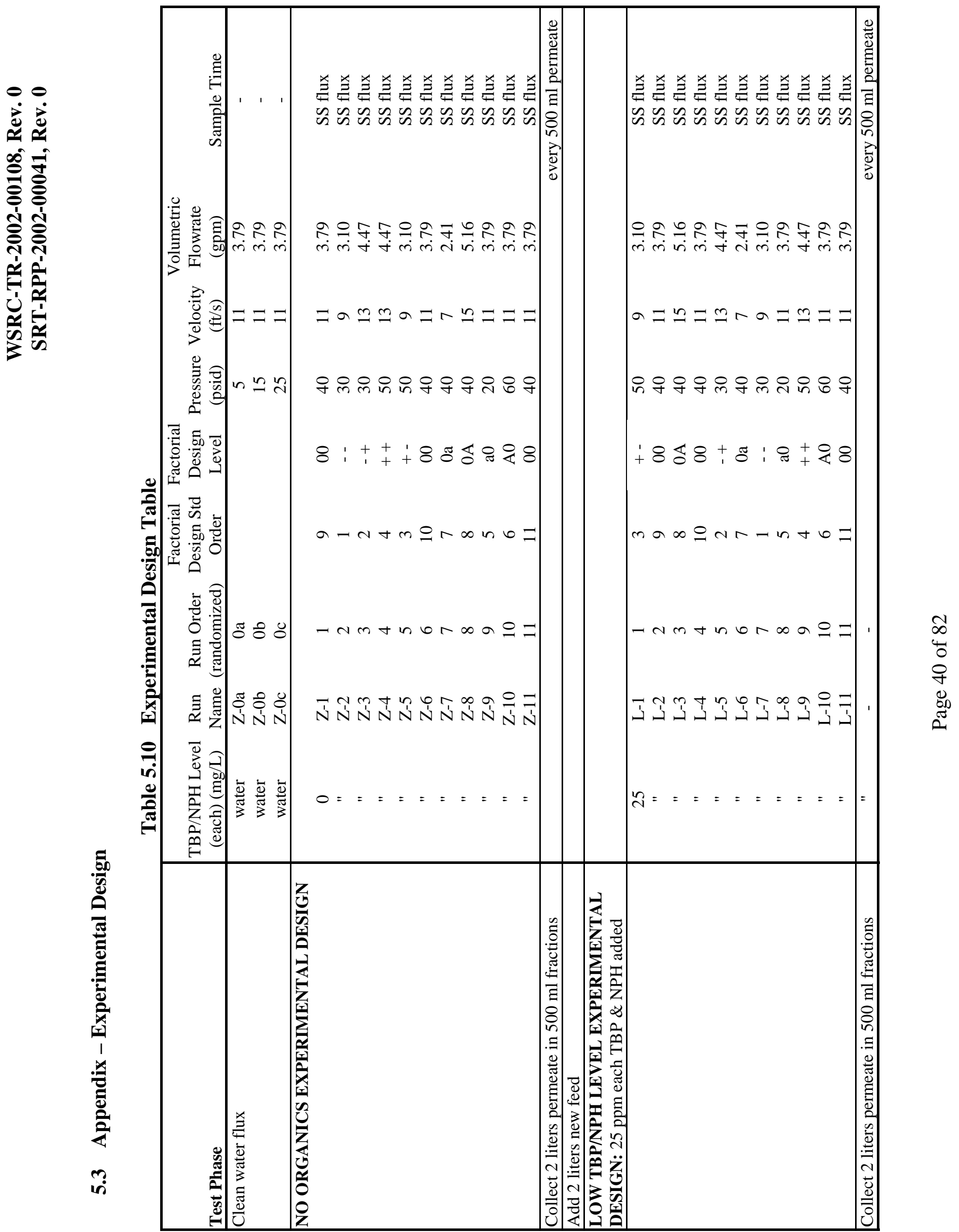


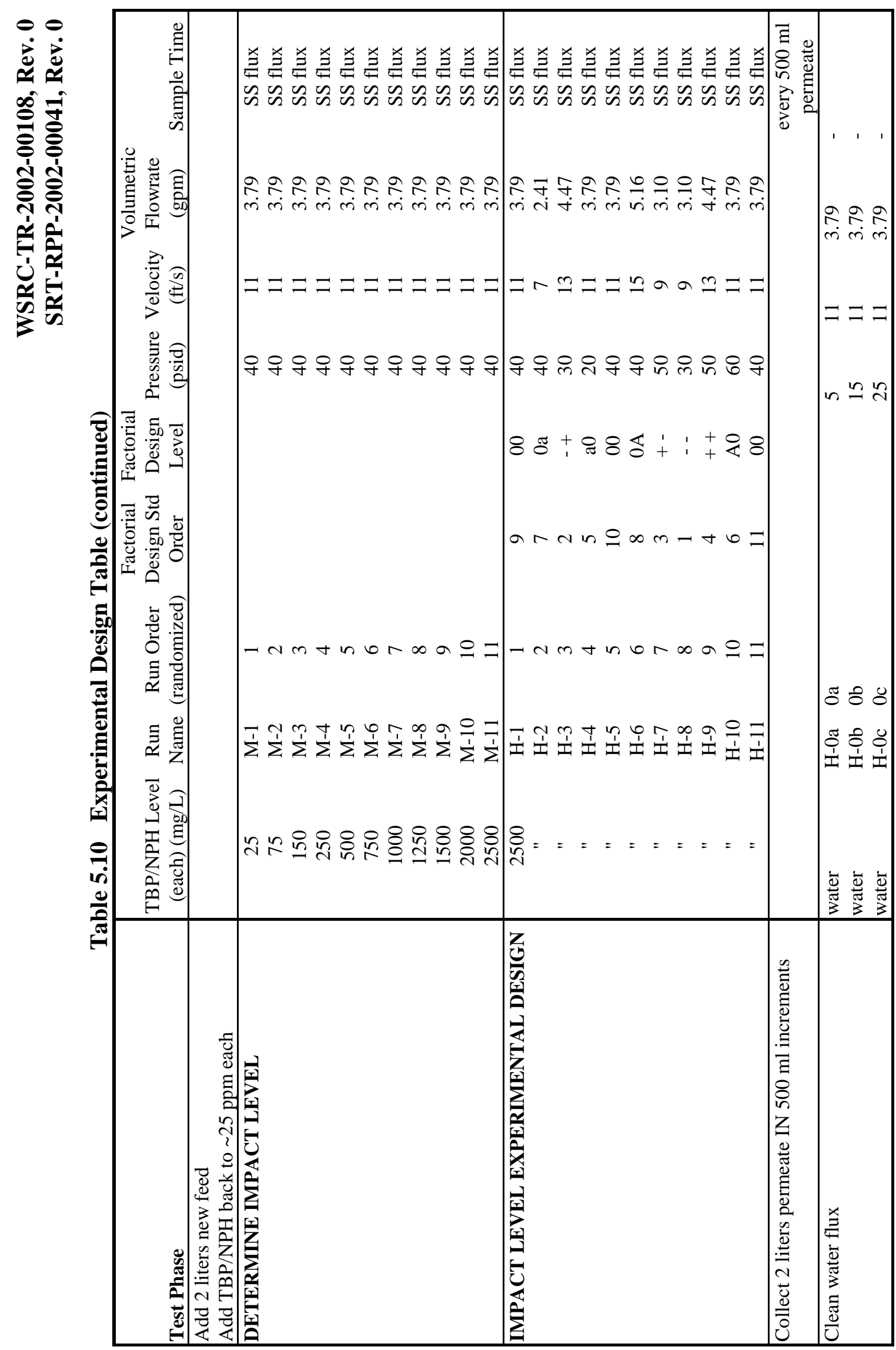




\begin{tabular}{|c|c|c|c|c|c|c|c|c|c|c|c|c|c|c|c|c|c|c|c|c|c|c|c|c|c|c|}
\hline 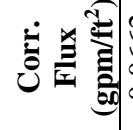 & 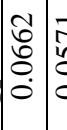 & 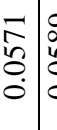 & 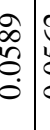 & 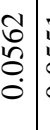 & $\begin{array}{l}\vec{n} \\
\vdots \\
0 \\
0\end{array}$ & 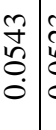 & & & $\begin{array}{l}\infty \\
\tilde{n} \\
0 \\
0 \\
0\end{array}$ & $\begin{array}{l}0 \\
\tilde{m} \\
0 \\
0 \\
0\end{array}$ & $\begin{array}{l}\hat{\tilde{n}} \\
\hat{\sigma} \\
0\end{array}$ & $\left|\begin{array}{c}0 \\
0 \\
0 \\
0 \\
0\end{array}\right|$ & $\begin{array}{c}0 \\
\tilde{c} \\
0 \\
0 \\
0\end{array}$ & 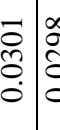 & & $\begin{array}{l}1 \\
0 \\
0 \\
0 \\
0\end{array}$ & 文 & $\begin{array}{l}n \\
\vdots \\
\vdots \\
0 \\
0\end{array}$ & $\begin{array}{r}2 \\
\\
0 \\
0\end{array}$ & 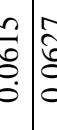 & 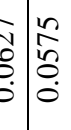 & 产 & 总 & $\bar{\delta}$ & $\begin{array}{l}2 \\
\hat{2} \\
0 \\
0 \\
0\end{array}$ & \\
\hline 宅 & 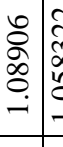 & 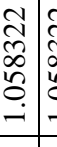 & 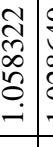 & 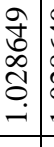 & 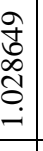 & 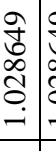 & 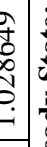 & & 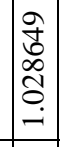 & 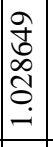 & 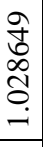 & & $\begin{array}{c}1 \\
\text { D } \\
\infty \\
o \\
- \\
-\end{array}$ & 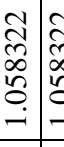 & 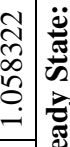 & 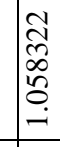 & 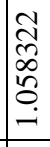 & 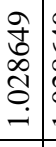 & 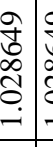 & 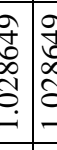 & 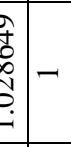 & 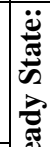 & $\begin{array}{l}5 \\
0 \\
0 \\
5 \\
0 \\
0\end{array}$ & & $\begin{array}{l}0 \\
0 \\
0 \\
\vdots \\
0 \\
0\end{array}$ & \\
\hline छิ & $\approx$ & $\tilde{\imath}$ & $\approx$ & $\dot{\sim}$ & $\underset{\sim}{\sim}$ & オ & I & & $\underset{\sim}{ \pm}$ & ন & $\stackrel{\Delta}{\sim}$ & $\stackrel{\imath}{\sim}$ & $\tilde{\Theta}$ & $\approx$ & 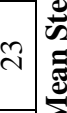 & 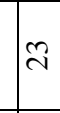 & 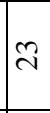 & $\mathbb{d}$ & $\dot{\sim}$ & $\Delta$ & 寸 & 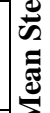 & $\bar{\imath}$ & $\infty$ & $\stackrel{\infty}{\sim}$ & \\
\hline 总 & $\mid \begin{array}{l}0 \\
0 \\
2 \\
0 \\
0 \\
0\end{array}$ & 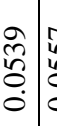 & \begin{tabular}{l|l}
$\tilde{n}$ & \\
$\vdots$ \\
0 \\
0
\end{tabular} & $\begin{array}{l}0 \\
0 \\
⿱ \\
0 \\
0 \\
0\end{array}$ & & 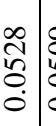 & $\begin{array}{l}0 \\
0 \\
b \\
6\end{array}$ & & $\begin{array}{c}\stackrel{2}{\hat{े}} \\
\hat{0} \\
\dot{0}\end{array}$ & & & $\mid \begin{array}{c}\infty \\
0 \\
⿱ 0 \\
0 \\
0\end{array}$ & 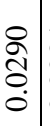 & 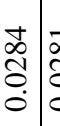 & & $\begin{array}{l}0 \\
0 \\
0 \\
0 \\
0\end{array}$ & $\begin{array}{l}0 \\
0 \\
0 \\
0\end{array}$ & \begin{tabular}{l}
$\infty$ \\
\multirow{2}{*}{} \\
$\vdots$ \\
0 \\
0
\end{tabular} & 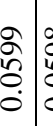 & & & & 命 & & ల్ & \\
\hline
\end{tabular}

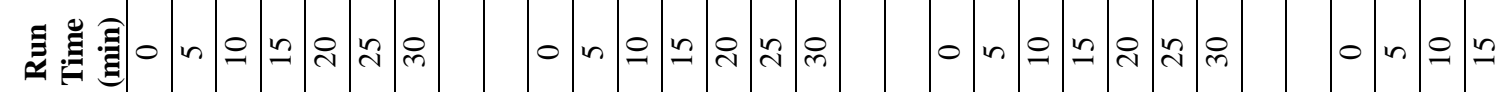

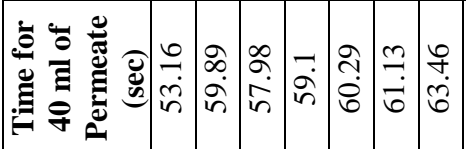

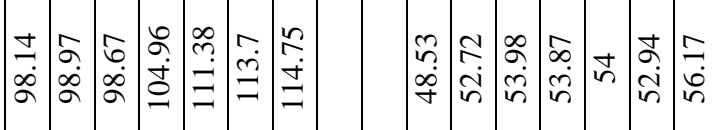

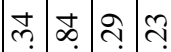

a

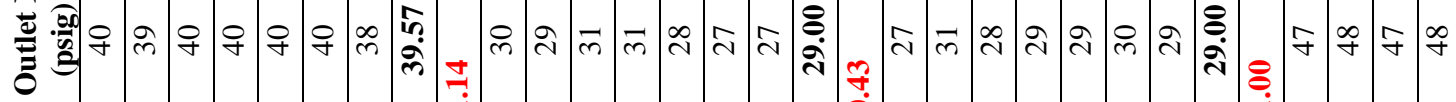

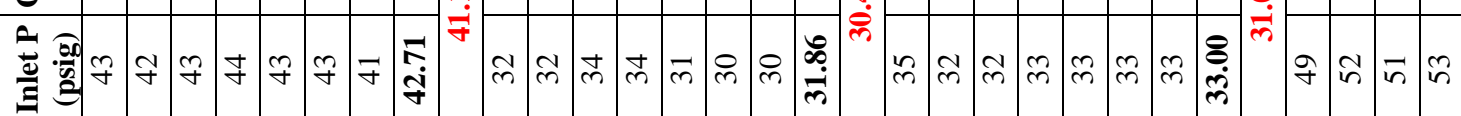

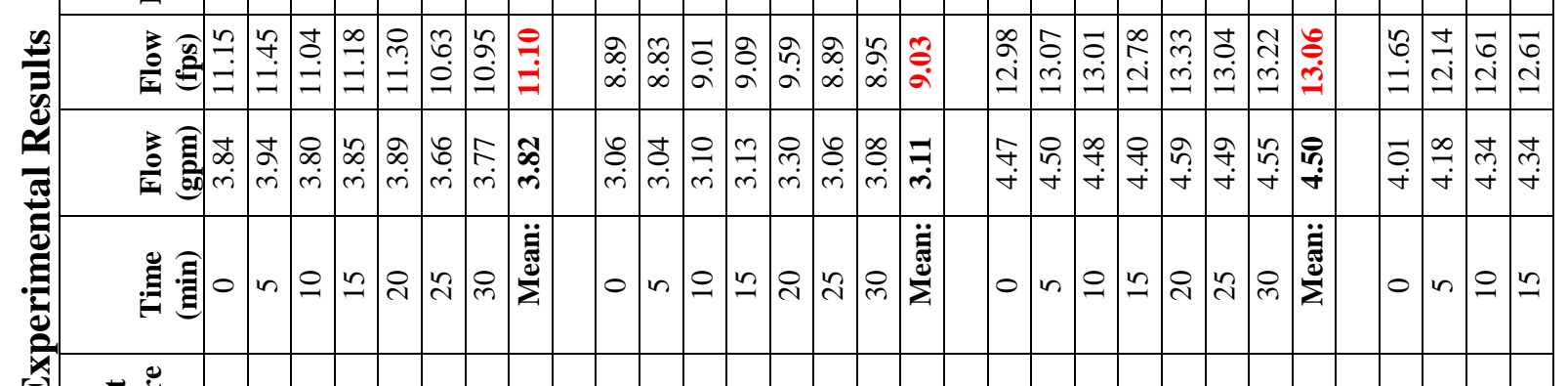

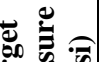

ले

요

in

$=$

2 


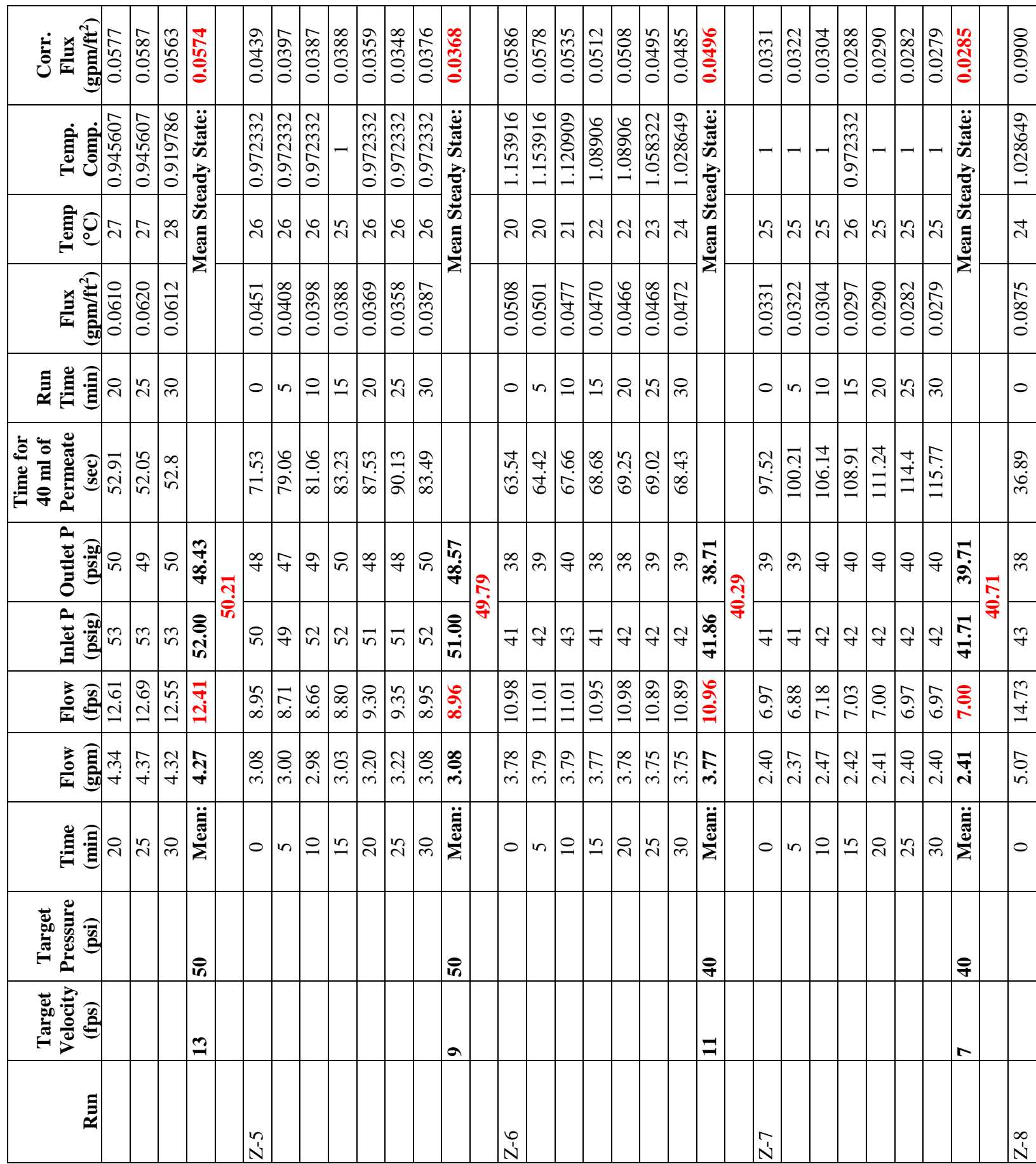




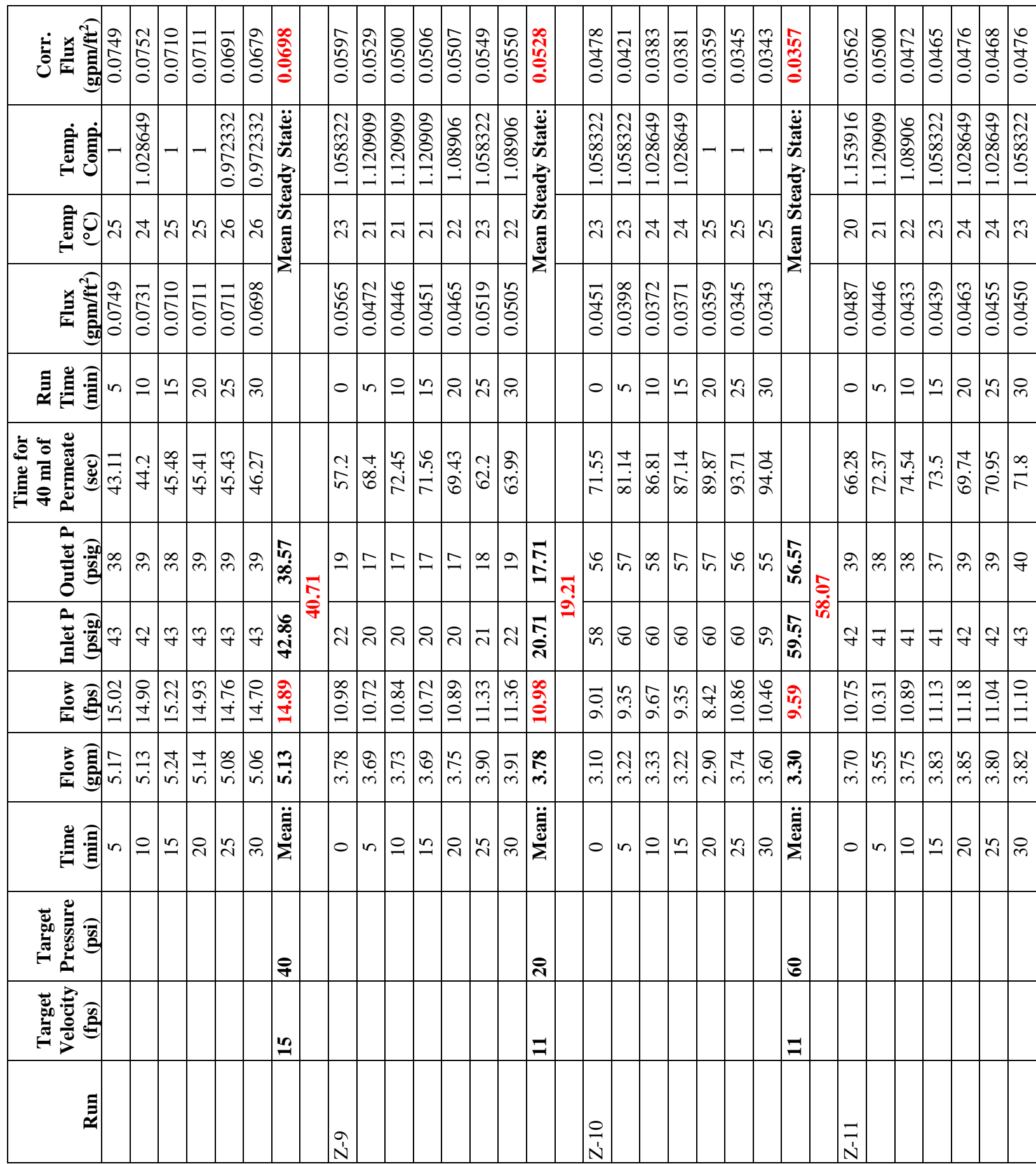




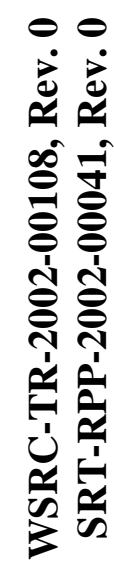

\begin{tabular}{|c|c|c|c|c|c|c|c|c|c|c|c|c|c|c|c|c|c|c|c|c|c|c|c|}
\hline 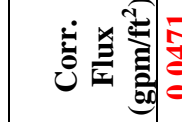 & 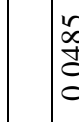 & $\begin{array}{l}0 \\
\vdots \\
\vdots \\
\vdots\end{array}$ & 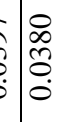 & & 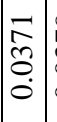 & & 递 & & 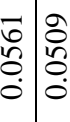 & 定 & 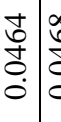 & & & $\mid$ & $\mid \begin{array}{l}0 \\
0 \\
0 \\
0 \\
0 \\
0\end{array}$ & 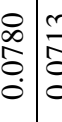 & & | & 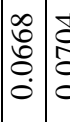 & \begin{tabular}{l}
0 \\
$\vdots$ \\
\hdashline
\end{tabular} & $\begin{array}{l}\overline{\tilde{n}} \\
\hat{0} \\
0 \\
0\end{array}$ & $\mid \begin{array}{l}0 \\
\vec{a} \\
0 \\
0 \\
0\end{array}$ & 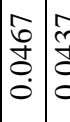 \\
\hline 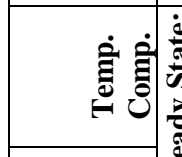 & $\begin{array}{l}\tilde{n} \\
\hat{\tilde{E}} \\
\vdots \\
0 \\
0\end{array}$ & 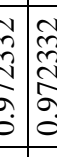 & & - & 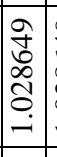 & & 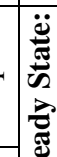 & 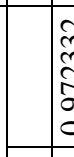 & 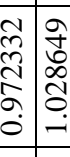 & 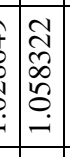 & & & & $\mid$ & - & 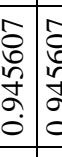 & & & - & 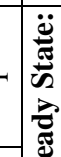 & - & 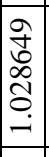 & 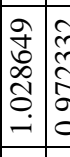 \\
\hline 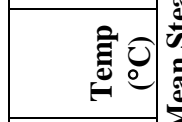 & & 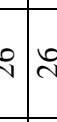 & $\underset{\pi}{4}$ & 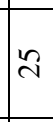 & d & $\dot{4}$ & 离 & & i) & $\pi$ & & & $\approx$ & 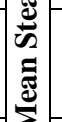 & $i$ & $\hat{\imath} \hat{\jmath}$ & & 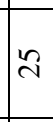 & $\approx \approx$ & 竎 & $\approx$ & A & İ \\
\hline 美昰昰 & $\begin{array}{l}0 \\
0 \\
0 \\
0 \\
0 \\
0\end{array}$ & 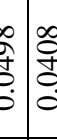 & 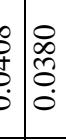 & $\begin{array}{l}0 \\
0 \\
0 \\
0 \\
0 \\
0\end{array}$ & $\mid \begin{array}{l}0 \\
0 \\
0 \\
0 \\
0 \\
0\end{array}$ & 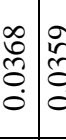 & & & 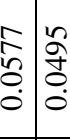 & 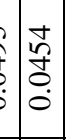 & 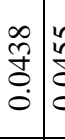 & $\mid \begin{array}{ll}0 \\
y \\
d \\
d\end{array}$ & $\begin{array}{l}F \\
\\
0 \\
0\end{array}$ & & $\begin{array}{l}0 \\
\infty \\
\infty \\
0 \\
0 \\
0\end{array}$ & 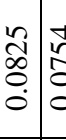 & & $\begin{array}{l}\infty \\
0 \\
0 \\
0 \\
0 \\
\end{array}$ & 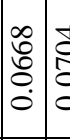 & & $\begin{array}{l}\bar{n} \\
\ddot{0} \\
0 \\
0\end{array}$ & \begin{tabular}{|l}
0 \\
0 \\
0 \\
0 \\
0 \\
0
\end{tabular} & 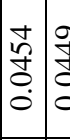 \\
\hline 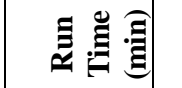 & 0 & & 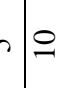 & $\simeq$ & ని & 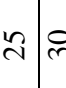 & & & 0 in & 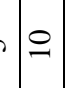 & $\approx \delta$ & 4 & $\ddot{n}$ & & 0 & in 5 & 2 & ๙ & भब & & 0 & in & $\because$ : \\
\hline 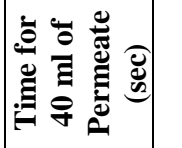 & & & & & $\mid \begin{array}{l}\infty \\
0 \\
\vdots \\
\infty \\
\infty\end{array}$ & & & & 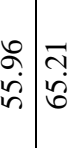 & 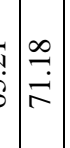 & & & 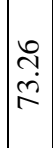 & & $\mid$ & 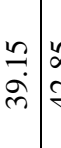 & & $\begin{array}{l}m \\
\infty \\
\alpha \\
\alpha\end{array}$ & 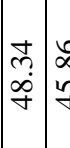 & & $\begin{array}{l}\infty \\
0 \\
\dot{\theta} \\
\dot{0}\end{array}$ & $\begin{array}{l}\infty \\
0 \\
\dot{0} \\
0\end{array}$ & 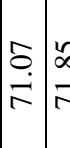 \\
\hline 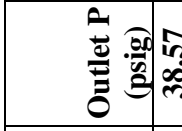 & 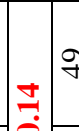 & 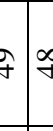 & of & $\infty$ & $\infty$ & in & के & & ल) & $\dot{m}$ & $\hat{m}:$ & & $\infty$ & 胥 & $\underline{m}$ & ले & & i & $\infty$ & $\begin{array}{l}f \\
q \\
m \\
m\end{array}$ & $\infty$ & ले & $\stackrel{m}{m}$ \\
\hline 言僉 & is & 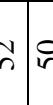 & 89 & in & $\bar{n}$ & $n=$ & 禹 & & q & F & $q=$ & $f$ & $F$ & 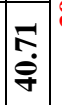 & 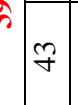 & $q=$ & $f F$ & $F$ & $g=$ & $\frac{7}{9}$ & $\bar{F}$ & 7 & ले $=$ \\
\hline 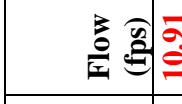 & $\frac{1}{\infty}$ & 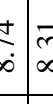 & $\overrightarrow{0}$ & 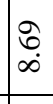 & $\begin{array}{l}0 \\
0 \\
\infty\end{array}$ & 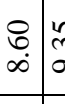 & $\frac{\pi}{\infty}$ & & 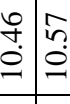 & 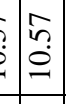 & $\begin{array}{l}8 \\
: \\
:\end{array}$ & a & \begin{tabular}{|l}
$\vec{\sigma}$ \\
$\dot{\Xi}$
\end{tabular} & 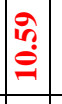 & $\mid \begin{array}{c}0 \\
\stackrel{0}{a} \\
\end{array}$ & $\stackrel{5}{\stackrel{2}{*}}$ & $\begin{array}{l}\vdots \\
\vdots \\
\vdots\end{array}$ & $\begin{array}{l}\hat{2} \\
\dot{I} \\
\dot{I}\end{array}$ & 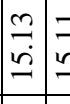 & $\begin{array}{l}\stackrel{\infty}{\infty} \\
\dot{\Xi}\end{array}$ & $\stackrel{\overbrace{}}{\Xi}$ & $\mid \begin{array}{l}n \\
\vdots \\
0 \\
0 \\
\end{array}$ & 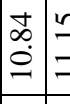 \\
\hline 童嵫 & & $\underbrace{}_{i}$ & : & बे & $\hat{\hat{i}}$ & $\grave{i}$ & $\overbrace{\infty}$ & & : & $\begin{array}{l}\vec{b} \\
b \\
\vec{r}\end{array}$ & के & हु & $\stackrel{2}{i}$ & 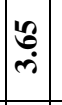 & $\begin{array}{c}\mathcal{A} \\
\text { nu. }\end{array}$ & 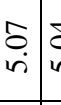 & 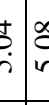 & î & 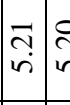 & $\frac{9}{40}$ & $\begin{array}{l}\tilde{D} \\
\infty \\
\dot{m}\end{array}$ & 常 & 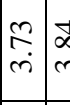 \\
\hline 毛国 & c & on & 0 & $\cong$ & i & $\sqrt[4]{4}$ & : & & 0 in & 0 & $\cong \delta$ & 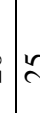 & 요 & 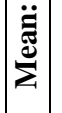 & 0 & ins & $=4$ & ণิ & भु) & ? & 0 & in & 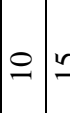 \\
\hline 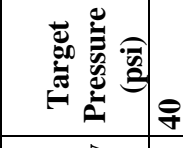 & & & & & & & in & & & & & & & \& & & & & & & \& & & & \\
\hline 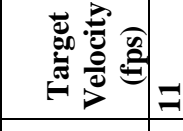 & & & & & & & $a$ & & & & & & & $=$ & & & & & & 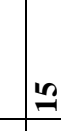 & & & \\
\hline & 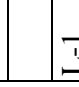 & & & & & & & & 豞 & & & & & & 3 & & & & & & 先 & & \\
\hline
\end{tabular}




\begin{tabular}{|c|c|c|c|c|c|c|c|c|c|c|c|c|c|c|c|c|c|c|c|c|c|c|c|c|c|c|c|c|}
\hline 已 & & 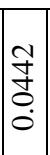 & . & $\mid \begin{array}{l}10 \\
\stackrel{1}{8} \\
\stackrel{0}{0}\end{array}$ & $\begin{array}{l}n \\
\stackrel{2}{5} \\
0 \\
0\end{array}$ & $\begin{array}{l}\infty \\
0 \\
0 \\
0 \\
0\end{array}$ & $\begin{array}{l}\infty \\
0 \\
2 \\
0 \\
0\end{array}$ & 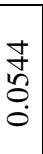 & \begin{tabular}{l}
+ \\
\multirow{2}{n}{} \\
0 \\
0
\end{tabular} & $\begin{array}{l}0 \\
\stackrel{0}{0} \\
\vdots \\
0 \\
0\end{array}$ & & 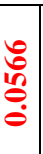 & $\begin{array}{c}\vec{n} \\
\tilde{0} \\
\dot{0}\end{array}$ & $\mid \begin{array}{l}n \\
\overline{0} \\
0 \\
0\end{array}$ & $\begin{array}{l}\tilde{c} \\
\infty \\
\tilde{\Xi} \\
0 \\
0\end{array}$ & \begin{tabular}{l}
0 \\
\multirow{2}{0}{} \\
0 \\
0
\end{tabular} & $\left|\begin{array}{c}\hat{0} \\
0 \\
0 \\
0\end{array}\right|$ & 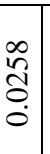 & $\mid \begin{array}{l}n \\
\vdots \\
\delta \\
0 \\
0 \\
0\end{array}$ & 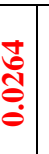 & 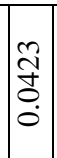 & $\begin{array}{l}0 \\
0 \\
\vdots \\
0 \\
0\end{array}$ & \begin{tabular}{l|l}
$\infty$ & 1 \\
$\hat{2}$ & $\vdots$ \\
$\vdots$ & $\vdots$
\end{tabular} & & 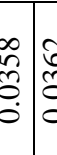 & 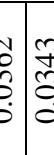 & 总 & $\mid \begin{array}{l}0 \\
+ \\
0 \\
0 \\
0 \\
0\end{array}$ \\
\hline 苞㝘 & & - & - & 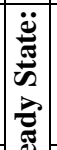 & 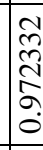 & $\begin{array}{l}\tilde{N} \\
\hat{\widehat{N}} \\
\hat{\alpha} \\
\hat{\delta}\end{array}$ & - & - & - & 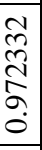 & 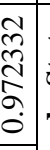 & 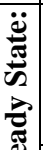 & $\begin{array}{c}\tilde{N} \\
\tilde{N} \\
\infty \\
0 \\
0 \\
-\end{array}$ & 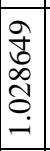 & - & - & 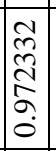 & - & 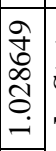 & 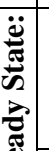 & -1 & - & -1 & 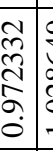 & 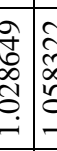 & 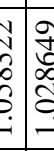 & 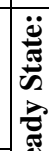 & - \\
\hline 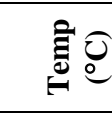 & & $\mathrm{c}$ & $\ddot{3}$ & 苛 & $\approx$ & 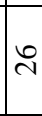 & $\ddot{\imath}$ & 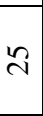 & 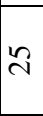 & il & $\stackrel{\sim}{~}$ & 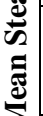 & $\tilde{\lambda}$ & ¿ & 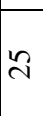 & $\ddot{\imath}$ & $\stackrel{\sim}{*}$ & 2 & I & 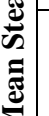 & $\gtrsim$ & $\sqrt{2}$ & $\ddot{\imath}$ & $\underset{\sim}{2}$ & J & 3. & |⿹ & iิ \\
\hline 胥 & & \begin{tabular}{l}
2 \\
\multirow{2}{*}{} \\
0 \\
0 \\
0
\end{tabular} & in & & 芯 & $\begin{array}{l}\frac{n}{8} \\
\frac{0}{0} \\
0\end{array}$ & $\begin{array}{l}\infty \\
0 \\
0 \\
0 \\
0 \\
0\end{array}$ & & \begin{tabular}{l}
+ \\
\multirow{2}{2}{} \\
$\vdots$ \\
0
\end{tabular} & $\begin{array}{l}1 \\
\infty \\
2 \\
0 \\
0 \\
0\end{array}$ & 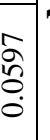 & & 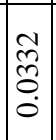 & 点 & $\begin{array}{l}2 \\
0 \\
0 \\
0 \\
0 \\
0\end{array}$ & $\mid$\begin{tabular}{l}
0 \\
\multirow{2}{0}{} \\
0 \\
0 \\
0
\end{tabular} & 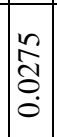 & 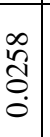 & $\mid \begin{array}{l}0 \\
\stackrel{0}{0} \\
\text { O } \\
\dot{0}\end{array}$ & & $\begin{array}{c}\widetilde{2} \\
\stackrel{T}{0} \\
0 \\
0\end{array}$ & $\begin{array}{l}0 \\
\vdots \\
\vdots \\
0 \\
0\end{array}$ & 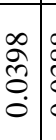 & 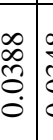 & 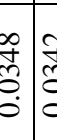 & 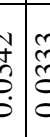 & & \begin{tabular}{l}
0 \\
\multirow{1}{*}{} \\
?. \\
0
\end{tabular} \\
\hline
\end{tabular}

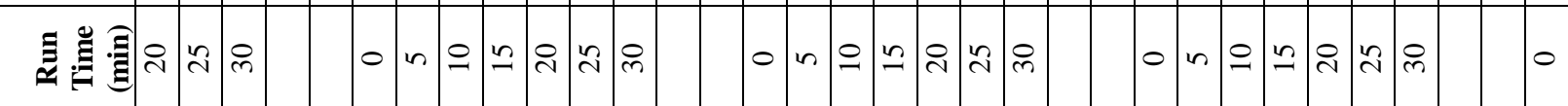

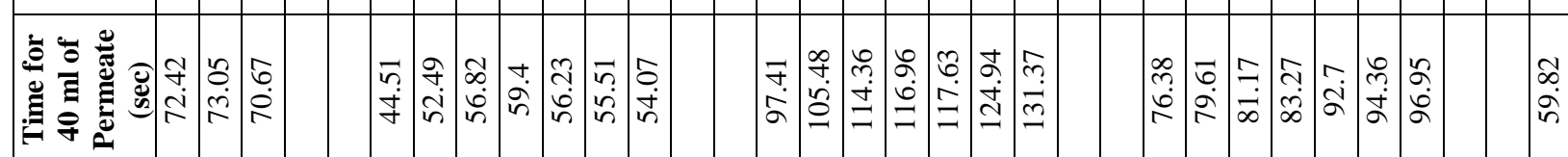

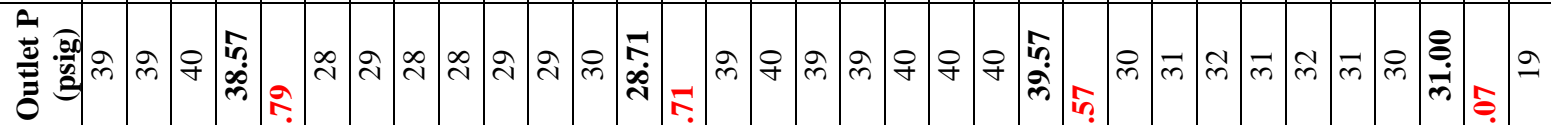

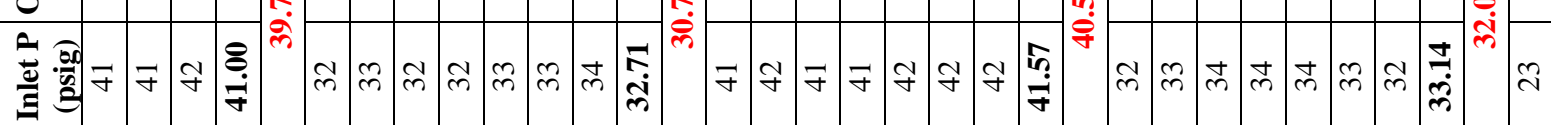

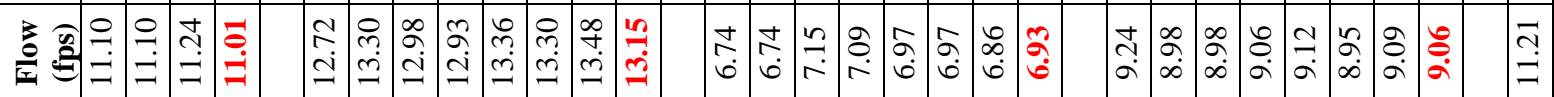

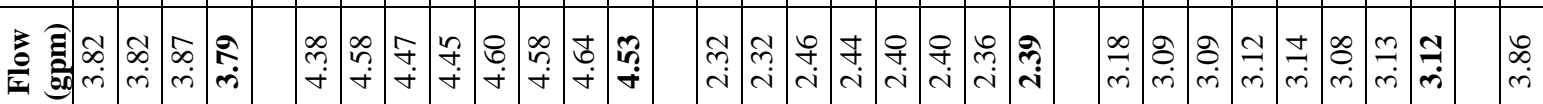

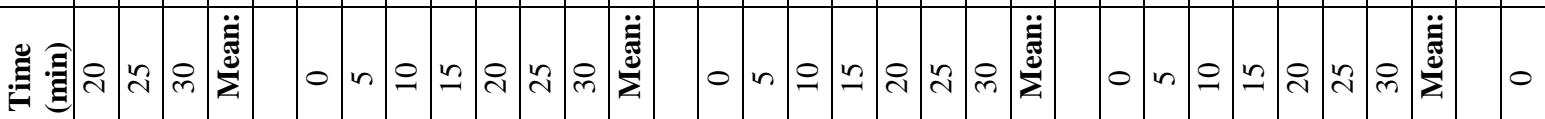

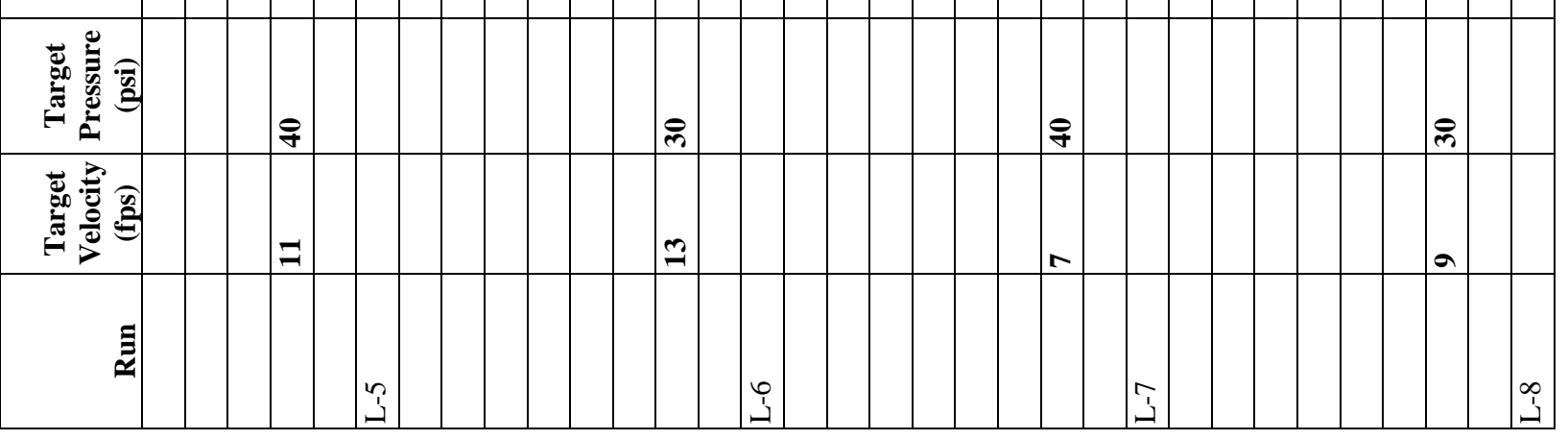




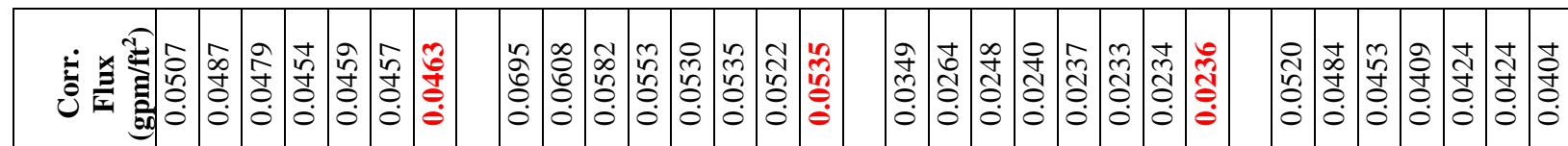

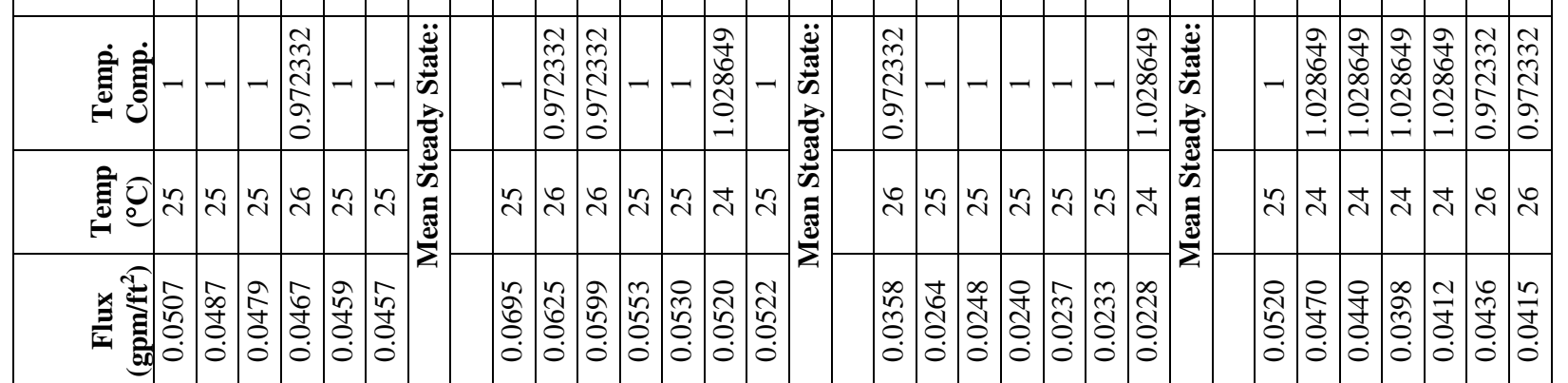

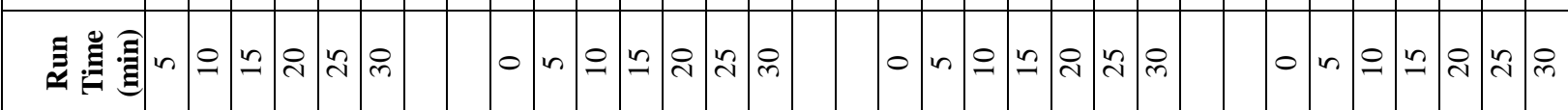

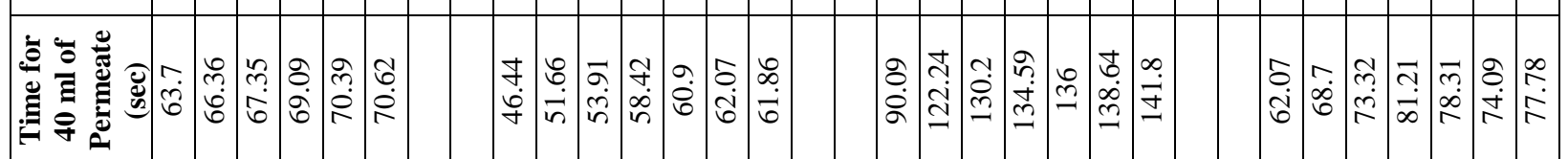

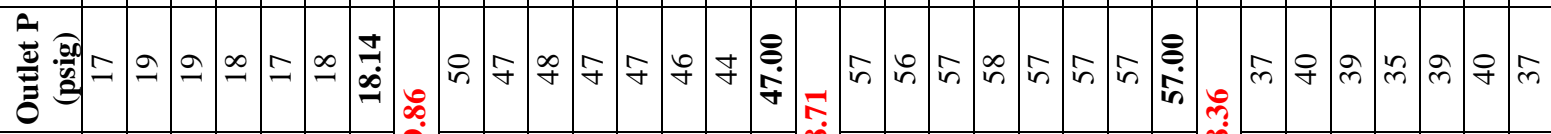

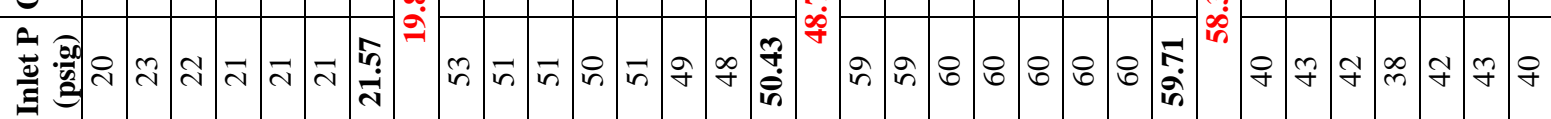
言 है I ब्र

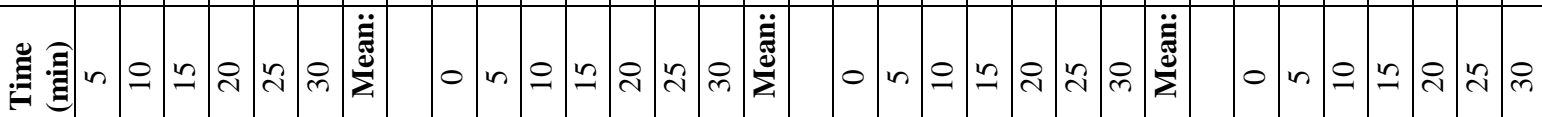

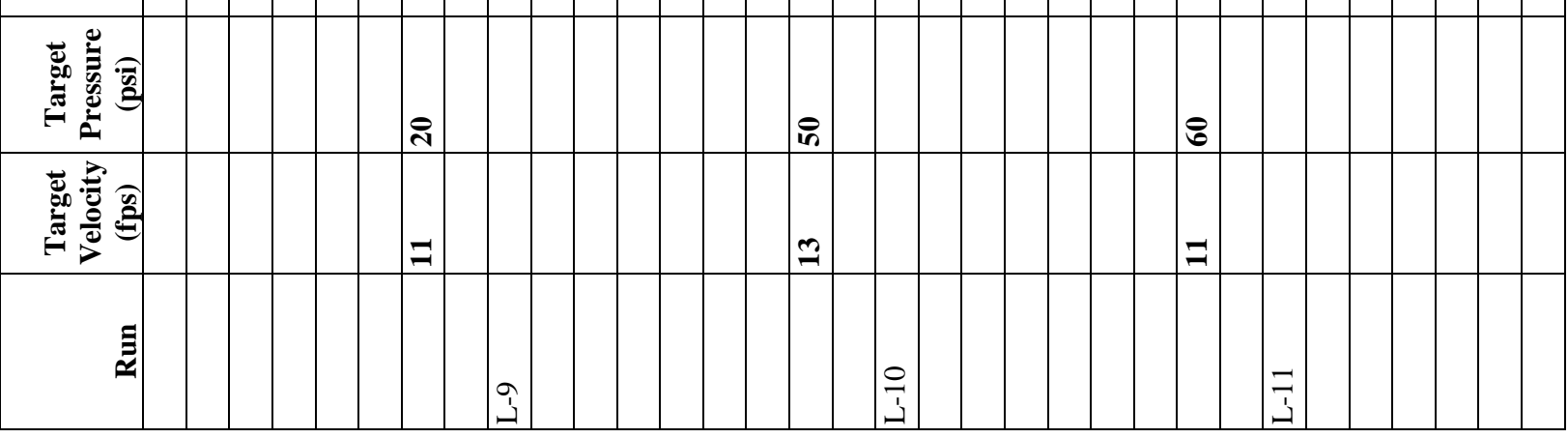




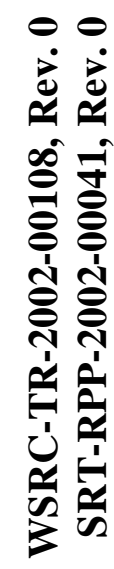

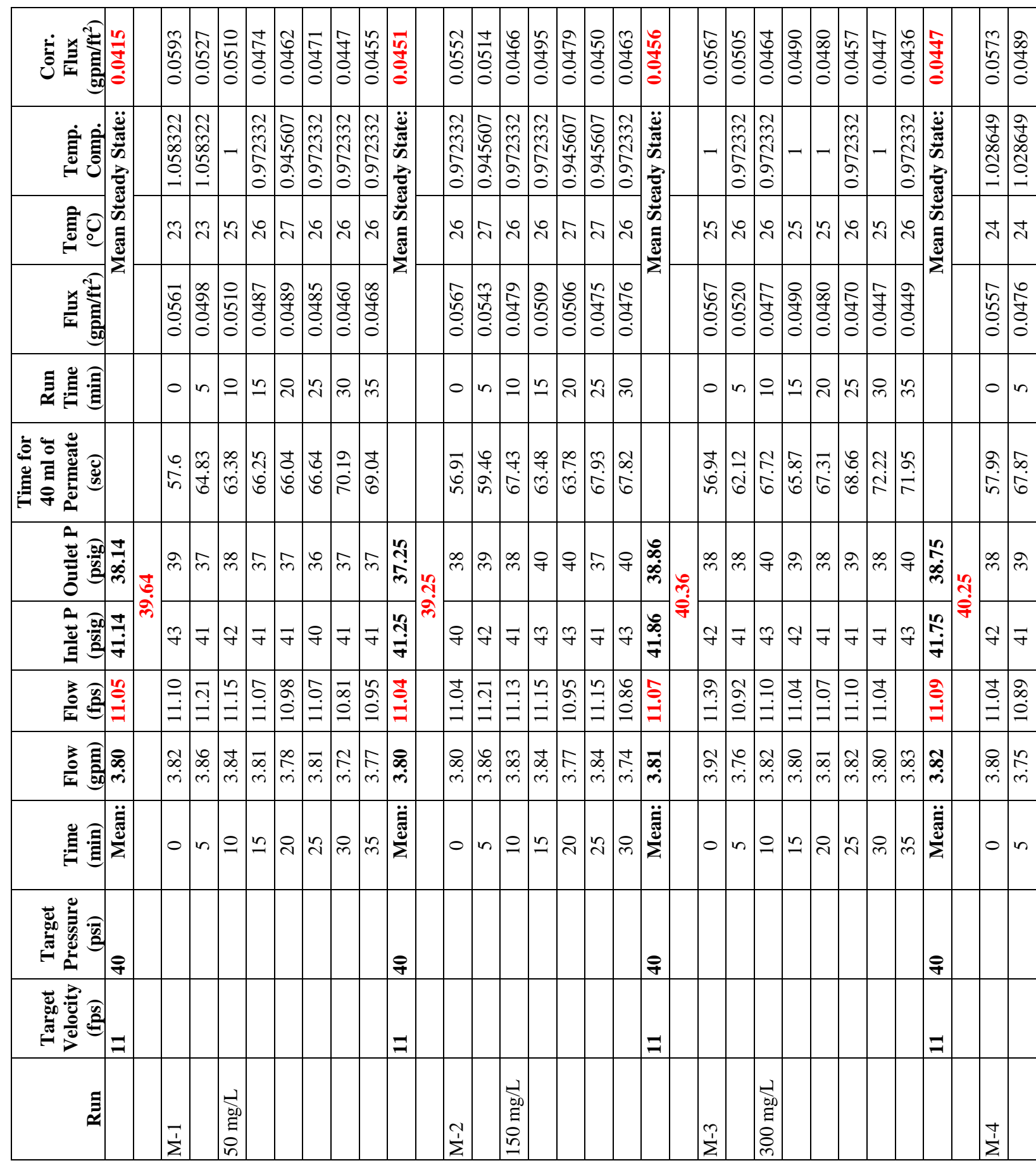




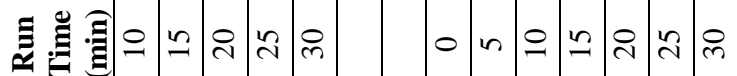

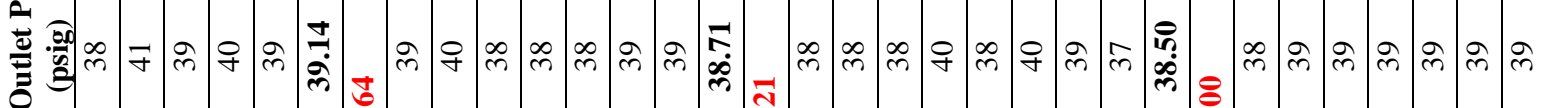

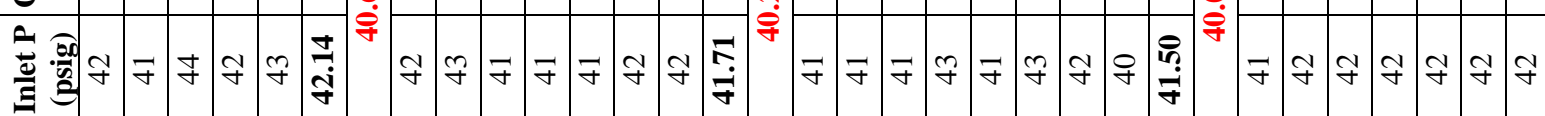

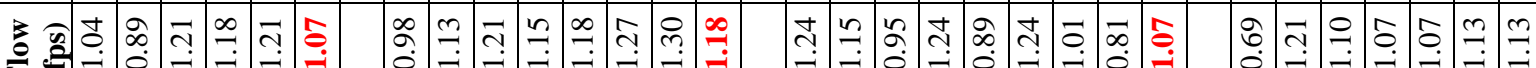

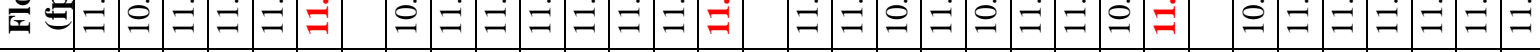

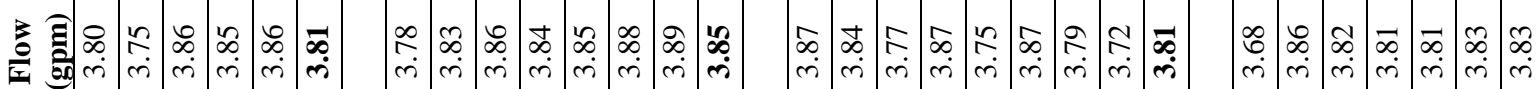

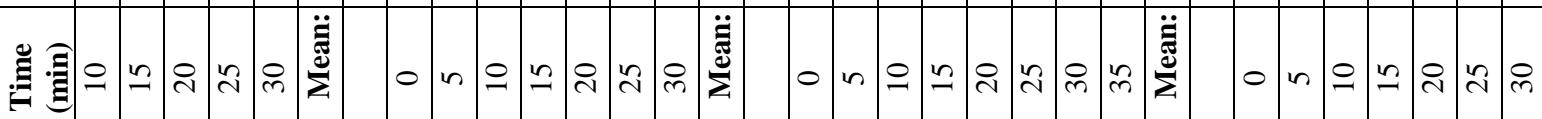

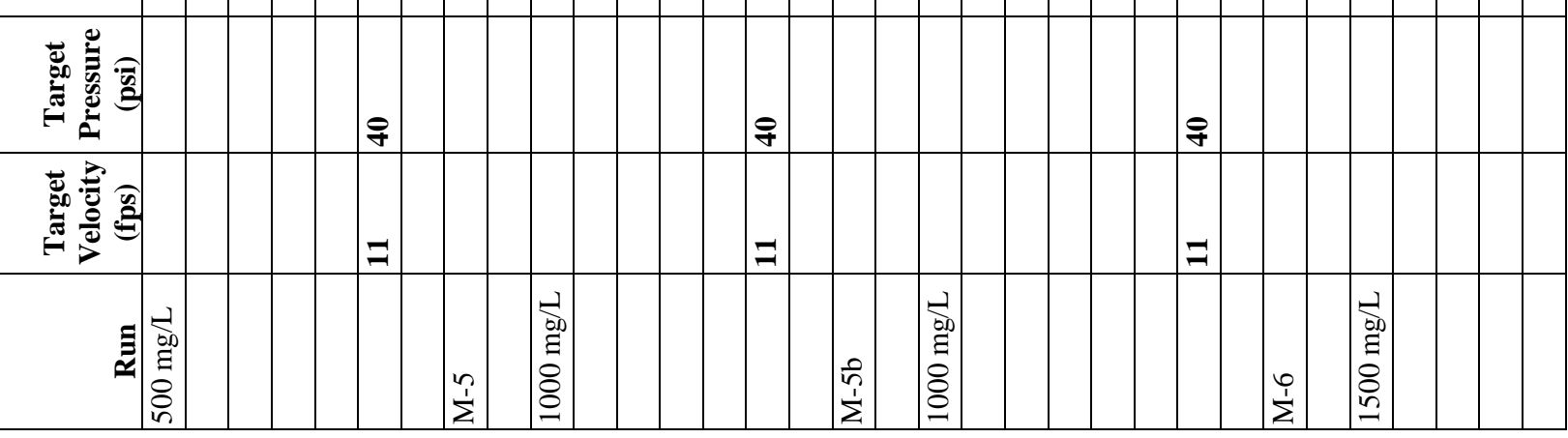




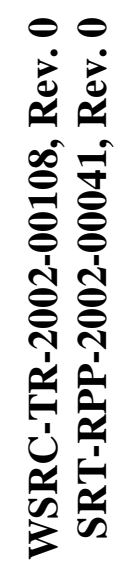

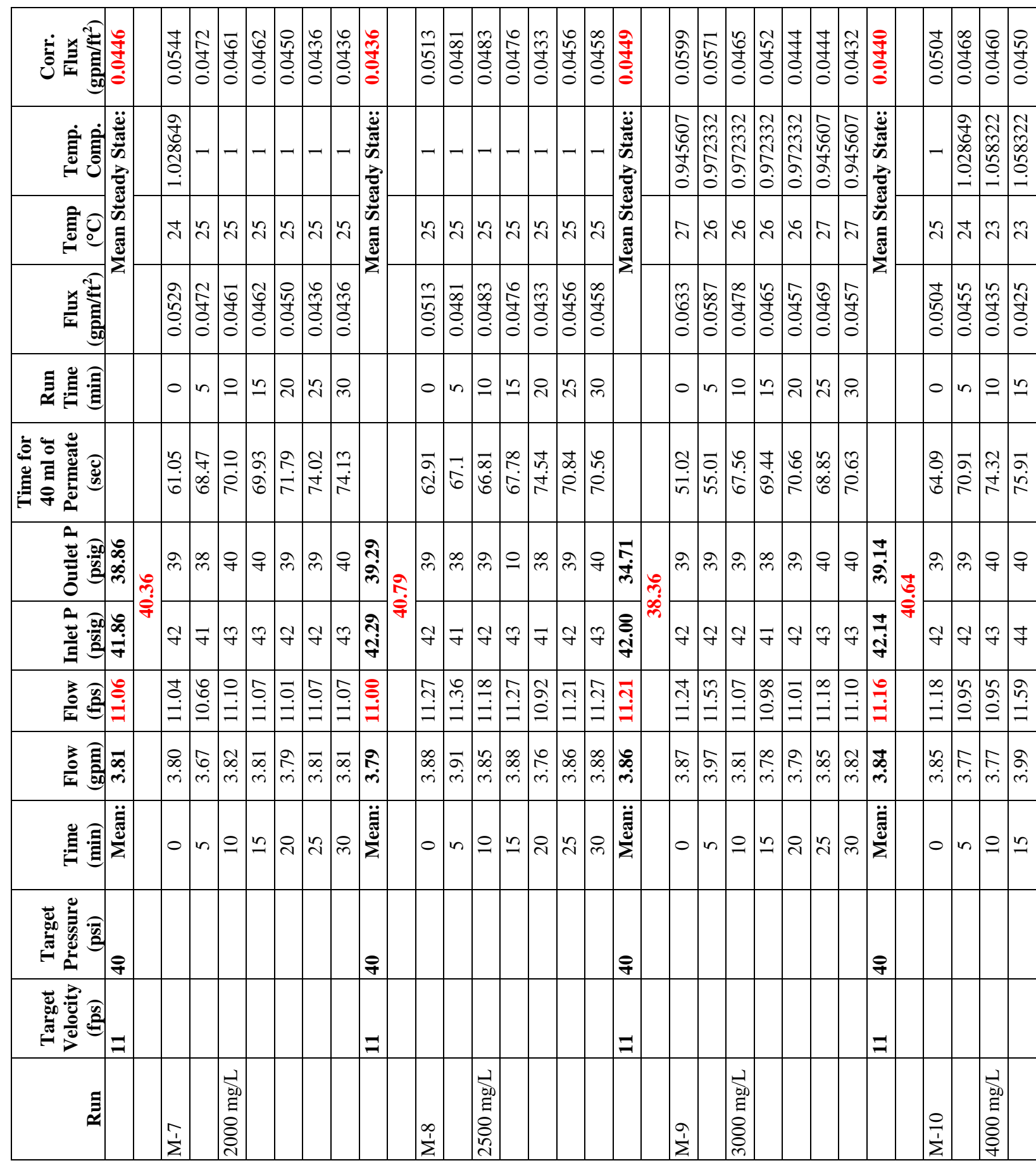




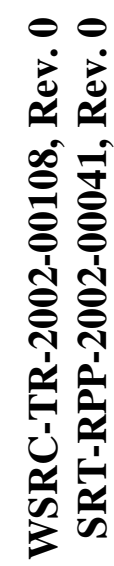

\begin{tabular}{|c|c|c|c|c|c|c|c|c|c|c|c|c|c|c|c|c|c|c|c|c|c|c|c|c|c|c|c|c|c|}
\hline 芦关氞 & & 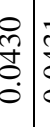 & $\begin{array}{l}\overrightarrow{0} \\
\stackrel{9}{0} \\
\\
0\end{array}$ & 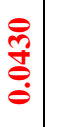 & 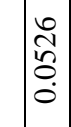 & 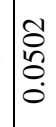 & 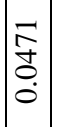 & 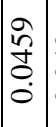 & 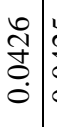 & 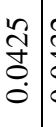 & 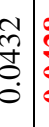 & 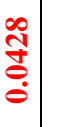 & $\begin{array}{l}0 \\
2 \\
2 \\
0 \\
0\end{array}$ & $\mid \begin{array}{l}\infty \\
\infty \\
0 \\
0 \\
0\end{array}$ & $\begin{array}{l}\infty \\
0 \\
0 \\
0 \\
0\end{array}$ & $\left|\begin{array}{l}8 \\
0 \\
0 \\
0 \\
0\end{array}\right|$ & 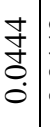 & \begin{tabular}{l|l}
\multirow{2}{*}{} \\
\multirow{2}{*}{} \\
0 \\
0
\end{tabular} & $\begin{array}{ll}m \\
\stackrel{O}{0} \\
0 \\
\dot{0}\end{array}$ & 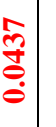 & $\mid$\begin{tabular}{c}
0 \\
\hdashline \\
0 \\
0 \\
0
\end{tabular} & $\mid \begin{array}{l}\infty \\
0 \\
0 \\
0 \\
0 \\
0\end{array}$ & \begin{tabular}{l|l}
$\Delta$ & \\
$\grave{\Delta}$ & \\
$\dot{0}$ &
\end{tabular} & & & & & & 竜 \\
\hline 完 & & 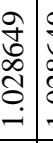 & $\begin{array}{l}a \\
b \\
0 \\
\text { ô. } \\
\\
\end{array}$ & 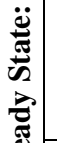 & $\mid \begin{array}{l}\tilde{1} \\
\tilde{2} \\
\infty \\
\tilde{o} \\
-1 \\
-1\end{array}$ & 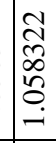 & $\begin{array}{l}\tilde{1} \\
\tilde{\infty} \\
\infty \\
0 \\
- \\
\end{array}$ & 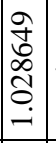 & - & -1 & 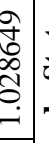 & 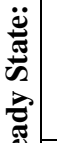 & $\begin{array}{l}0 \\
\text { d } \\
\infty \\
\text { dै } \\
\text { - } \\
-\end{array}$ & - & 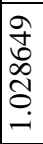 & $\left|\begin{array}{c}\tilde{N} \\
\tilde{\infty} \\
0 \\
0 \\
-1\end{array}\right|$ & 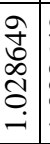 & 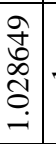 & - & 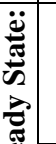 & - & 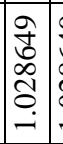 & 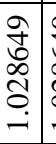 & & 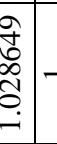 & -1 & 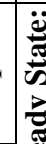 & & -1 \\
\hline 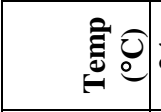 & & ন & 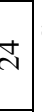 & 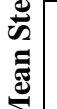 & $\hat{\imath}$ & $\tilde{\lambda}$ & $\vec{\lambda}$ & $\stackrel{\Delta}{\sim}$ & $\approx$ & 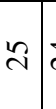 & $\dot{J}$ & 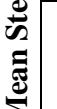 & I & 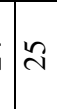 & $\underset{\sim}{ \pm}$ & $\lambda$ & $\underset{\sim}{\Delta}$ & 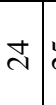 & $\approx$ & 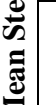 & $\approx$ & ম্র & $\stackrel{d}{d}$ & i & $\dot{\Delta}$ & $3 \cong$ & ส & & $\ddot{2}$ \\
\hline 总昰 & & $\begin{array}{l}\infty \\
+ \\
0 \\
0\end{array}$ & & $\Sigma$ & 命 & $\mid \begin{array}{l}0 \\
\frac{d}{7} \\
0\end{array}$ & \begin{tabular}{l}
0 \\
\multirow{0}{0}{} \\
0 \\
0
\end{tabular} & $\mid \begin{array}{l}0 \\
0 \\
0 \\
0 \\
0 \\
0\end{array}$ & 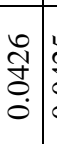 & 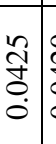 & 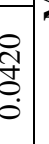 & $\Sigma$ & 号 & . & $\begin{array}{l}1 \\
0 \\
0 \\
0 \\
0\end{array}$ & $\left|\begin{array}{l}0 \\
0 \\
0 \\
0 \\
0\end{array}\right|$ & $\begin{array}{l}\tilde{N} \\
\tilde{O} \\
0 \\
0\end{array}$ & 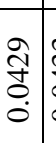 & 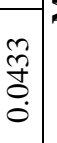 & $\Sigma$ & $\mid \begin{array}{c}0 \\
\tilde{\sigma} \\
0 \\
\dot{0}\end{array}$ & $\mid \begin{array}{c}0 \\
\infty \\
\tilde{D} \\
0 \\
0\end{array}$ & 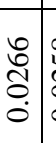 & 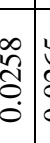 & 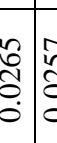 & & 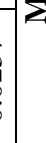 & & $\begin{array}{l}1 \\
0 \\
0 \\
0 \\
0\end{array}$ \\
\hline 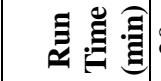 & & c) & ह্ল & & 0 & in & $\cong$ & $\because$ & त्र & $\approx$ & ల) & & 0 & in & 인 & $\because$ & तి & $\ddot{\lambda}$ & লি & & 0 & in & 으 & $\approx$ & ¿ి & $\mathrm{v}$ & & & 0 \\
\hline 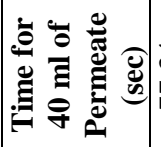 & & 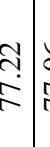 & & & $\left|\begin{array}{l}\hat{a} \\
\dot{d}\end{array}\right|$ & $\mid \begin{array}{l}0 \\
\dot{0} \\
\infty\end{array}$ & $\begin{array}{l}\hat{b} \\
i \\
i\end{array}$ & 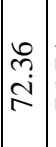 & 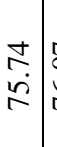 & \begin{tabular}{l}
5 \\
$\dot{0}$ \\
\hdashline
\end{tabular} & & & $\begin{array}{l}\circ \\
\stackrel{8}{\circ} \\
\text { in }\end{array}$ & $\begin{array}{l}2 \\
8 \\
8\end{array}$ & $\frac{0}{8}$ & $\mid$ & $\begin{array}{l} \pm \\
\vdots \\
\dot{J}\end{array}$ & 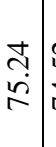 & $\begin{array}{l}\tilde{n} \\
\stackrel{+}{+}\end{array}$ & & $\mid \begin{array}{c}m \\
\stackrel{m}{0} \\
\dot{d}\end{array}$ & $\mid \begin{array}{l}n \\
m \\
\\
= \\
\vdots\end{array}$ & $\begin{array}{c}\mathscr{m} \\
\stackrel{\vec{I}}{\Xi}\end{array}$ & $\begin{array}{l}\mathfrak{Z} \\
\dot{\mathfrak{d}} \\
\mathfrak{g}\end{array}$ & 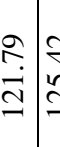 & & & & $\stackrel{\infty}{\stackrel{\leftrightarrow}{\sigma}}$ \\
\hline 离 & & ले & ले & बि. & ? & fo & $\stackrel{\infty}{\infty}$ & লे & ஸे & ले & o & 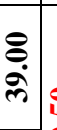 & के & $\infty$ & $\stackrel{\infty}{m}$ & q & ले & ले & ले & 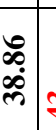 & $F$ & q & $\infty$ & ले & $F \Im$ & $\begin{array}{l}q \\
\end{array}$ & ले & సุ & बे \\
\hline 高惑 & & ㄱ & $q$ & 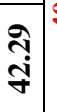 & $\mathscr{f}$ & $\mathscr{f}$ & $F$ & F & q) & F) & $q$ & 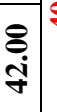 & F & $F$ & F & 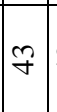 & ช & F) & F & 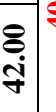 & $\mathscr{F}$ & $\mathscr{f}$ & $F$ & F & 寸 & $f \mid g$ & & $F$ & $\approx$ \\
\hline 言昰 & & $\begin{array}{l}\stackrel{0}{*} \\
=\end{array}$ & $\begin{array}{l}\infty \\
\dot{0} \\
0 \\
0\end{array}$ & 节 & $\stackrel{\vec{Y}}{=}$ & $\overrightarrow{\tilde{N}}$ & $\begin{array}{c}\overrightarrow{0} \\
\dot{\Xi}\end{array}$ & $\begin{array}{l}\tilde{\sigma} \\
\hat{\varrho}\end{array}$ & 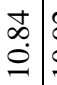 & $\begin{array}{l}\Omega \\
\varrho\end{array}$ & $\begin{array}{l}0 \\
\vdots \\
=\end{array}$ & $\stackrel{\varrho}{\Xi}$ & $\stackrel{\infty}{=}$ & 立 & 点 & $\stackrel{m}{\stackrel{2}{=}}$ & 色 & 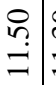 & $\stackrel{\text { }}{=}$ & 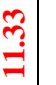 & $\bar{\sigma}$ & $\underset{7}{\stackrel{7}{r}}$ & $\stackrel{\infty}{\underset{r}{\sim}}$ & $\underset{\sim}{\infty}$ & 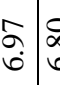 & 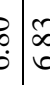 & $\underset{\dot{b}}{\stackrel{t}{r}}$ & & $\begin{array}{l}\hat{\infty} \\
\stackrel{\jmath}{J}\end{array}$ \\
\hline 竞氞 & & 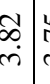 & $\begin{array}{l}n \\
c \\
m\end{array}$ & $\begin{array}{l}\infty \\
\dot{m} \\
\dot{m}\end{array}$ & $\mid \begin{array}{l}0 \\
\infty \\
\infty \\
m\end{array}$ & $\begin{array}{l}\infty \\
\infty \\
\infty\end{array}$ & 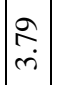 & $\begin{array}{l}\stackrel{0}{2} \\
\stackrel{m}{n}\end{array}$ & $\stackrel{m}{m}$ & \begin{tabular}{l|l}
$\stackrel{0}{2}$ & \\
$\dot{m}$ &
\end{tabular} & 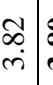 & के & $\begin{array}{l}n \\
\infty \\
\infty\end{array}$ & $\stackrel{\infty}{\stackrel{\infty}{m}}$ & $\begin{array}{l}\infty \\
\dot{m} \\
m\end{array}$ & $\left|\begin{array}{c}m \\
\infty \\
\infty\end{array}\right|$ & $\begin{array}{l}\infty \\
\stackrel{n}{2}\end{array}$ & $\begin{array}{c}\stackrel{0}{2} \\
\grave{m}\end{array}$ & $\begin{array}{ll}\tilde{\sigma} & \\
\dot{m} & \end{array}$ & ले & $\left|\begin{array}{c}\infty \\
\tilde{i} \\
i\end{array}\right|$ & $\mid \begin{array}{ll}n \\
i n \\
i\end{array}$ & \begin{tabular}{c:c}
\multirow{f}{*}{} & $:$ \\
$i$ &
\end{tabular} & $\begin{array}{l}\underset{i}{+} \\
\dot{i}\end{array}$ & & 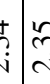 & i & & $\stackrel{?}{+}$ \\
\hline 总 昰 & & $\approx$ & e & 蔍 & 0 & in & 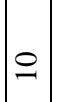 & $\because$ & ¿े. & $\approx$ & 8 & 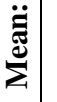 & 0 & n & 은 & $\because$ & ¿ & $\approx$ & s: & 节 & 0 & in & $\circ$ & $\because$ & ટે & $\mathrm{S}$ & : & & 10 \\
\hline 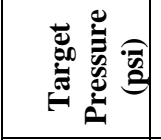 & & & & $q$ & & & & & & & & P & & & & & & & & f & & & & & & & & & \\
\hline 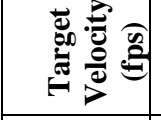 & & & & $=$ & & & & & & & & $\exists$ & & & & & & & & $\exists$ & & & & & & & $r$ & & \\
\hline$\Xi$ & & & & & $\bar{z}$ & & 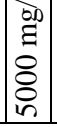 & & & & & & 土 & & & & & & & & $\mid \begin{array}{c}1 \\
\pm\end{array}$ & & & & & & & & II \\
\hline
\end{tabular}




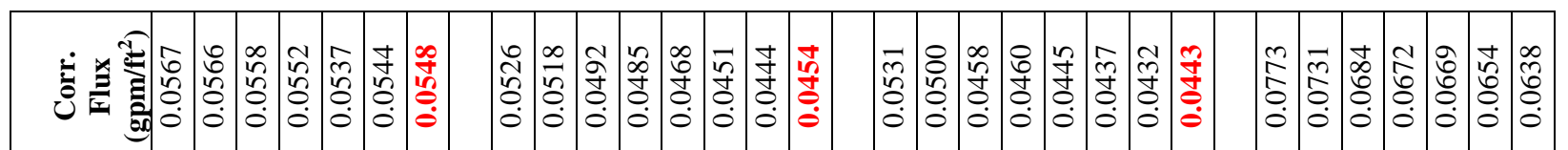

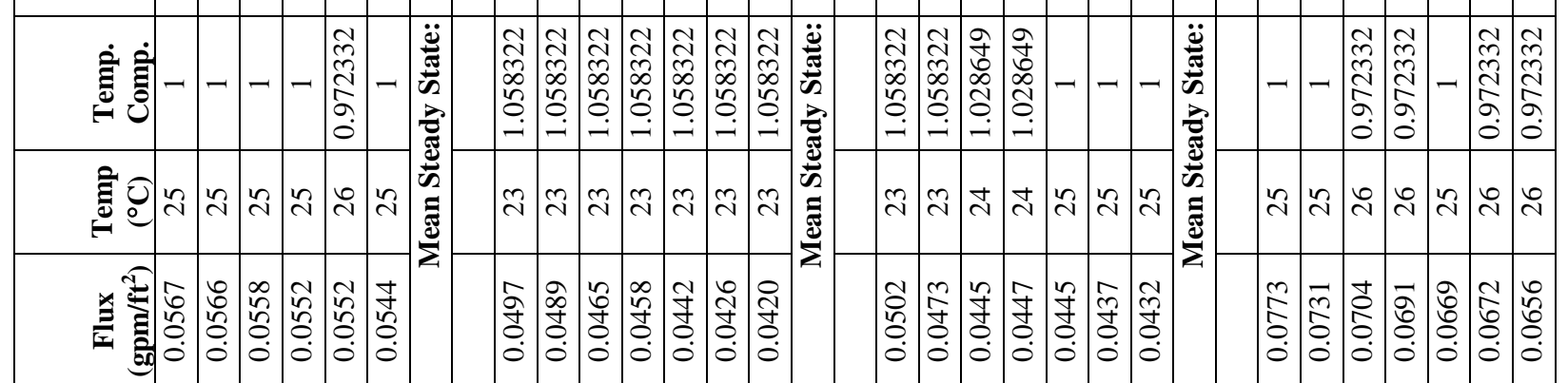

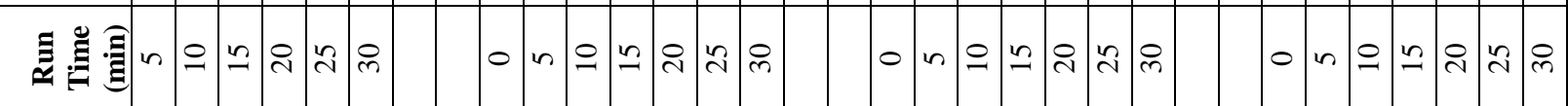

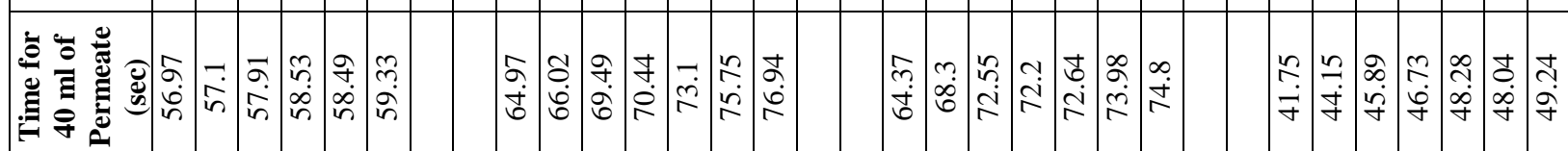

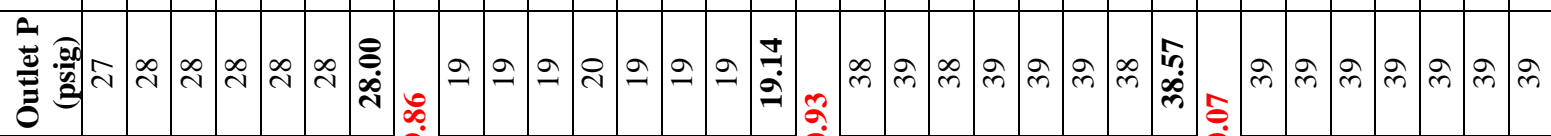
寻 宣

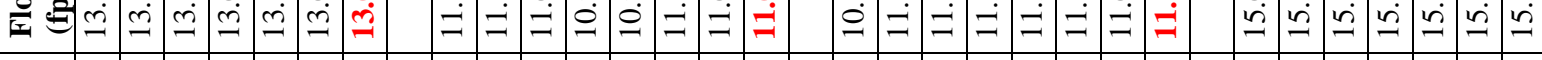

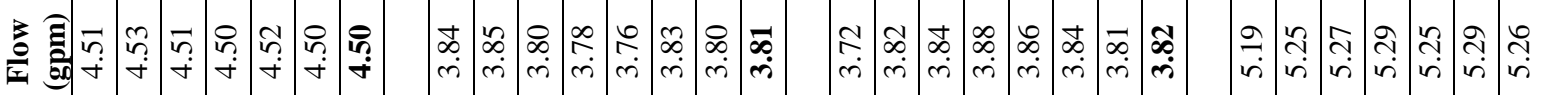

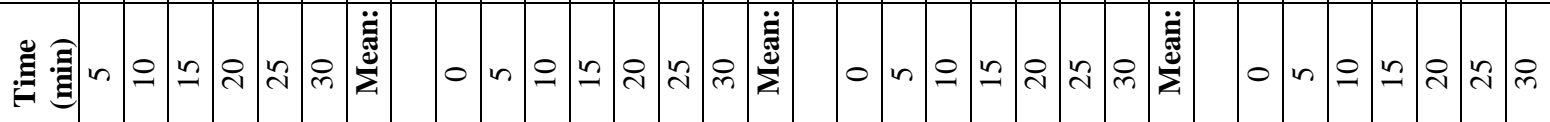

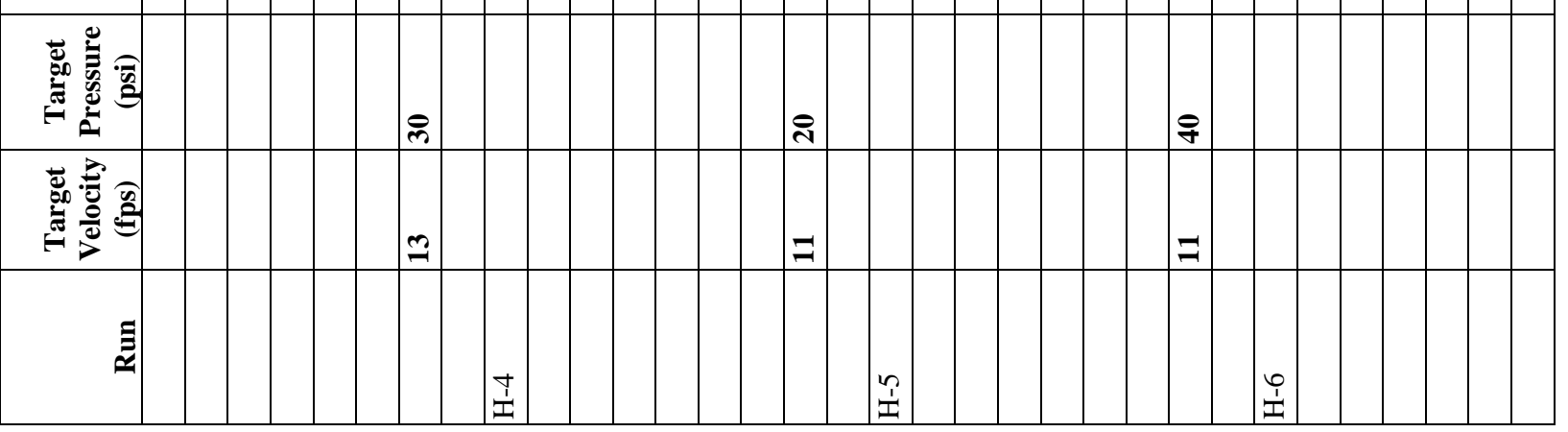




\begin{tabular}{|c|c|c|c|c|c|c|c|c|c|c|c|c|c|c|c|c|c|c|c|c|c|c|c|c|c|c|c|c|c|}
\hline 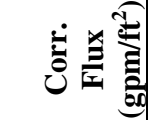 & & ô & 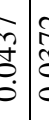 & 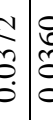 & 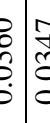 & 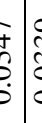 & $\hat{n}$ & है & $\begin{array}{c}\vec{\sigma} \\
0 \\
0 \\
0\end{array}$ & 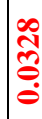 & & 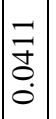 & \begin{tabular}{l|l}
$\infty$ & \\
$\infty$ & \\
0 & \\
0 &
\end{tabular} & 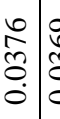 & 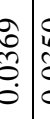 & 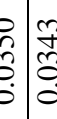 & 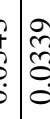 & Ş & & $\begin{array}{l}n \\
0 \\
0 \\
0 \\
0\end{array}$ & $\mid \begin{array}{c}\infty \\
0 \\
1 \\
0 \\
0 \\
0\end{array}$ & & 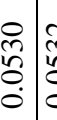 & 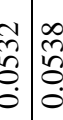 & bे & 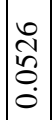 & 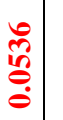 & 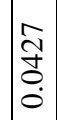 & $\begin{array}{l}\infty \\
\infty \\
\tilde{0} \\
0\end{array}$ \\
\hline 豈 & & - & -7 & -- & $-\mid \begin{array}{l}\tilde{N} \\
\tilde{z} \\
\vdots \\
\varrho\end{array}$ & 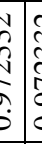 & 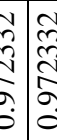 & - & -- & 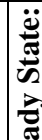 & & $\mid \begin{array}{l}\tilde{N} \\
\tilde{D} \\
\infty \\
0 \\
\\
-1\end{array}$ & 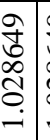 & 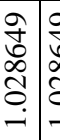 & 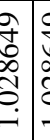 & 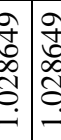 & 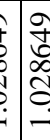 & 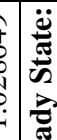 & & 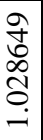 & - & 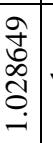 & - & - & 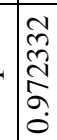 & 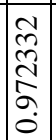 & $\mid$ & - & - \\
\hline 言 & & $\ddot{n}$ & 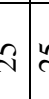 & $\vec{n}=$ & 9 & $\begin{array}{c}i \\
\end{array}$ & $\stackrel{i}{i} \underset{\sim}{0}$ & $\vec{b}$ & $\approx$ & 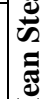 & & 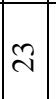 & $\underset{\sim}{\Delta}$ & $\stackrel{\sim}{\Delta}$ & 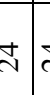 & $\stackrel{\sim}{\Delta}$ & 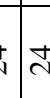 & 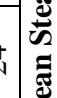 & & 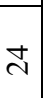 & 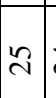 & $\vec{d}$ & 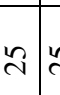 & $\tilde{c} \approx$ & i & 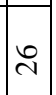 & 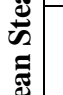 & $\ddot{\imath}$ & $\approx$ \\
\hline 羊言 & & Õ & 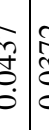 & 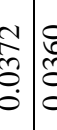 & 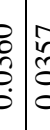 & & & & & & & $\left|\begin{array}{c}2 \\
\infty \\
\tilde{O} \\
0 \\
0\end{array}\right|$ & 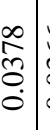 & 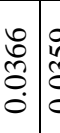 & & 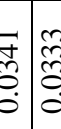 & & & & $\begin{array}{l}0 \\
0 \\
2 \\
0 \\
0\end{array}$ & $\mid \begin{array}{l}\infty \\
0 \\
⿱ \\
0 \\
0 \\
0\end{array}$ & 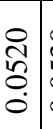 & 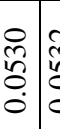 & 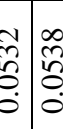 & 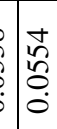 & 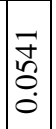 & & 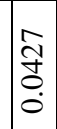 & $\begin{array}{l}\hat{\infty} \\
\infty \\
0 \\
0\end{array}$ \\
\hline 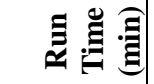 & & $o$ & 0 . & $n=$ & $2 !$ & $0 \delta$ & $\overrightarrow{2}$ & 10 & $n \approx m$ & & & 0 & ins & 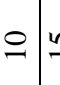 & $\approx \delta$ & c) & in & & & 0 & in & 0 & $\therefore$ & $\stackrel{\sim}{\sim}$ & i & $\stackrel{m}{m}$ & & 0 & in \\
\hline 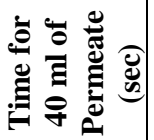 & & $\begin{array}{l}7 \\
\infty \\
n \\
n\end{array}$ & 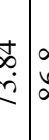 & \begin{tabular}{l|l}
$\infty$ & \multicolumn{6}{c}{} \\
$\dot{\infty}$ & \\
$\infty$ & $\alpha$
\end{tabular} & $\begin{array}{l}6 \\
0 \\
0 \\
0\end{array}$ & לे & 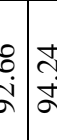 & 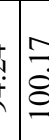 & $\begin{array}{l}n \\
\vdots \\
8 \\
8\end{array}$ & & & $\begin{array}{l}= \\
\dot{\infty} \\
\infty\end{array}$ & 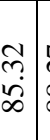 & 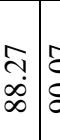 & & 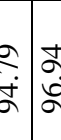 & & & & $\begin{array}{l}\infty \\
\stackrel{0}{0} \\
\stackrel{8}{n} \\
n\end{array}$ & $\left|\begin{array}{l}0 \\
\vdots \\
\infty \\
i n\end{array}\right|$ & 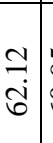 & \begin{tabular}{l|l}
2 & 7 \\
$\vdots$ & 7 \\
8 & 5
\end{tabular} & 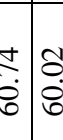 & 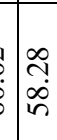 & $\begin{array}{l}50 \\
\dot{8}\end{array}$ & & $\begin{array}{l}\vec{b} \\
\stackrel{i}{r}\end{array}$ & $\begin{array}{l}\hat{m} \\
\hat{\infty}\end{array}$ \\
\hline 离 & & กิ & $g / g$ & $\infty ?$ & 89 & of & $n$ in & in & $g q$ & ָे & $\overrightarrow{\text { के }}$ & ঃ্রি & m) & तेః & हे & in & 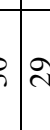 & רิ & s. & 누 & F & f & $\stackrel{\infty}{+}$ & $\infty \underset{+}{\infty} \stackrel{\infty}{+}$ & g & $\stackrel{\infty}{+}$ & 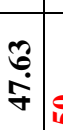 & in & in \\
\hline 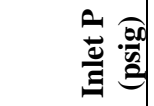 & & $\bar{F}$ & $\sqrt{n}$ & 品 is & 5 is & cis & $\sqrt{n}$ in & in & $\bar{n}$ & $\prod_{i}^{\infty}$ & & $m$ & $m$ & $\approx$ & $\mathrm{m}$ & $m \propto$ & $\approx$ & in & $\bar{m}$ & in & $\bar{n}$ & $\bar{n}$ & $\approx$ & $\tilde{i} \approx$ & $\bar{n}$ & $\approx$ & 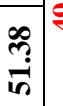 & 8 & $\infty$ \\
\hline 言氞 & & $\begin{array}{l}2 \\
\infty \\
\infty\end{array}$ & \begin{tabular}{l|l}
0 \\
$\infty$ \\
$\infty$ \\
$\infty$
\end{tabular} & $\begin{array}{lll}\infty & \alpha \\
\infty & 0 & 0 \\
\infty & \alpha\end{array}$ & $\begin{array}{l}\delta \\
\vdots \\
\vdots \\
\vdots\end{array}$ & $\begin{array}{l}x \\
\vdots \\
\vdots\end{array}$ & $\begin{array}{c}\int \\
\infty \\
\infty \\
\infty \\
\infty\end{array}$ & $\begin{array}{l}: \\
\vdots \\
\vdots \\
\vdots\end{array}$ & $\frac{\infty}{a}$ & $\begin{array}{l}\infty \\
\infty \\
\infty\end{array}$ & & $\left|\begin{array}{l}0 \\
\dot{\sigma} \\
\sigma\end{array}\right|$ & $\stackrel{?}{a}$ & \begin{tabular}{l}
$\infty$ \\
$\dot{a}$ \\
\hdashline
\end{tabular} & $\stackrel{a}{a}$ & 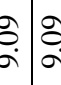 & $\int_{0}^{\circ}$ & : & & $\begin{array}{l}\tilde{b} \\
\dot{I}\end{array}$ & $\begin{array}{l}\hat{0} \\
\dot{j}\end{array} \mid$ & $\begin{array}{l}\stackrel{1}{a} \\
\mathrm{I}\end{array}$ & 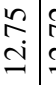 & $\begin{array}{l}\mathbb{N} \\
\vec{d}\end{array}$ & $\begin{array}{l}\infty \\
\vdots \\
\end{array}$ & $\begin{array}{l}\infty \\
\dot{I} \\
\beth\end{array}$ & $\begin{array}{l}\infty \\
\stackrel{1}{2} \\
\end{array}$ & $\vec{a}$ & $\frac{n}{a}$ \\
\hline 言 & & $\begin{array}{l}8 \\
m\end{array}$ & 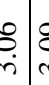 & $\begin{array}{l}\dot{b} \\
\dot{r}\end{array}$ & 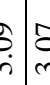 & 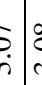 & 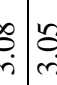 & $\frac{m}{m}$ & $\frac{0}{m}$ & ले & & $\frac{m}{m}$ & $\stackrel{\vec{m}}{\dot{m}}$ & \begin{tabular}{l|l}
$\stackrel{0}{m}$ & $=$ \\
$\dot{m}$ & $=$
\end{tabular} & $\underset{m}{ \pm}$ & $m: \frac{m}{m}$ & $\frac{\pi}{m}$ & $\frac{\vec{m}}{\dot{m}}$ & & $\begin{array}{l}\stackrel{?}{\sim} \\
\stackrel{+}{+}\end{array}$ & $\mid \begin{array}{c}\hat{m} \\
\dot{r}\end{array}$ & $\underset{+}{+}$ & 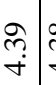 & 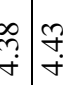 & 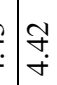 & $\underset{\dot{+}}{\overrightarrow{+}}$ & $\stackrel{f}{+}$ & 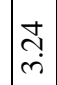 & $\frac{n}{m}$ \\
\hline 总司 & & 0 & 0 & $n \subseteq$ & E: & $a \delta$ & $\vec{v}:$ & () & $n \approx m$ & 节 & & 0 & in & $\circ 4$ & $\approx$ & 己े & ) & 2 & & 0 & in & 인. & $\because$ & 己े & i & $\tilde{m}$ & 蓆 & 0 & in \\
\hline 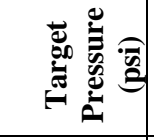 & f & & & & & & & & & in & & & & & & & & लि & & & & & & & & & in & & \\
\hline 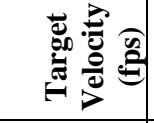 & 12 & & & & & & & & & $a$ & & & & & & & & $a$ & & & & & & & & & 2 & & \\
\hline & & \pm & I & & & & & & & & & $\mid \begin{array}{l}\infty \\
1 \\
\pm\end{array}$ & & & & & & & & ì & & & & & & & & $\frac{9}{1}$ & \\
\hline
\end{tabular}




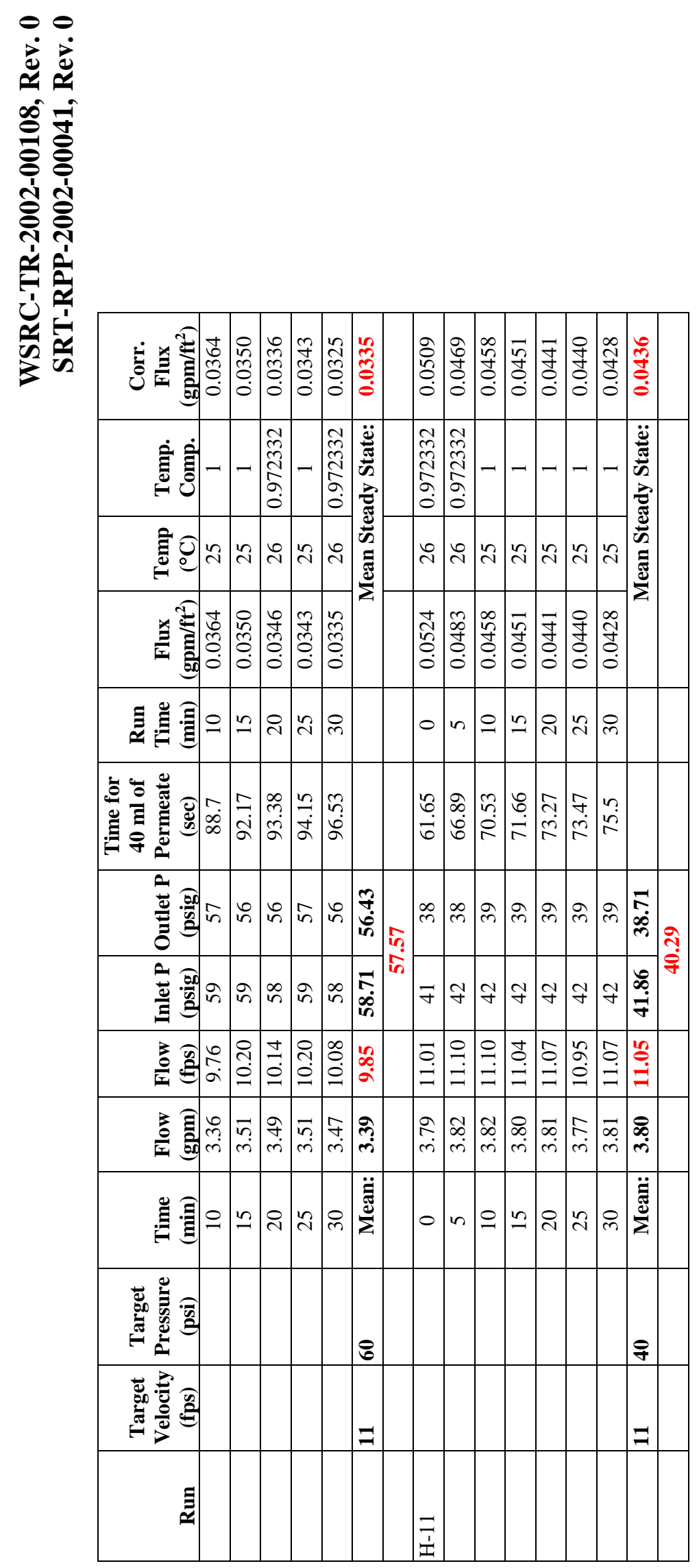


WSRC-TR-2002-00108, Rev. 0

SRT-RPP-2002-00041, Rev. 0
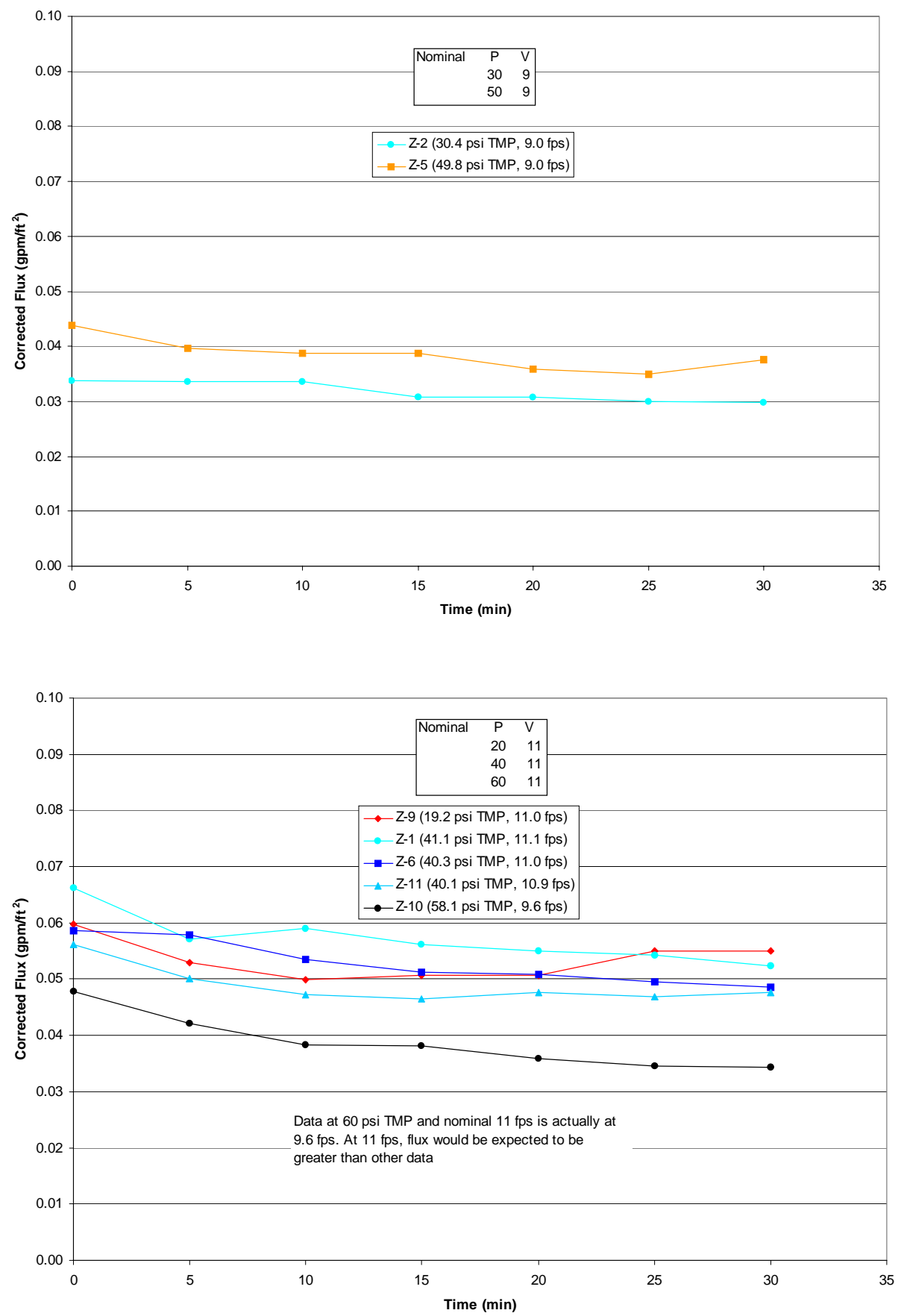
WSRC-TR-2002-00108, Rev. 0

SRT-RPP-2002-00041, Rev. 0
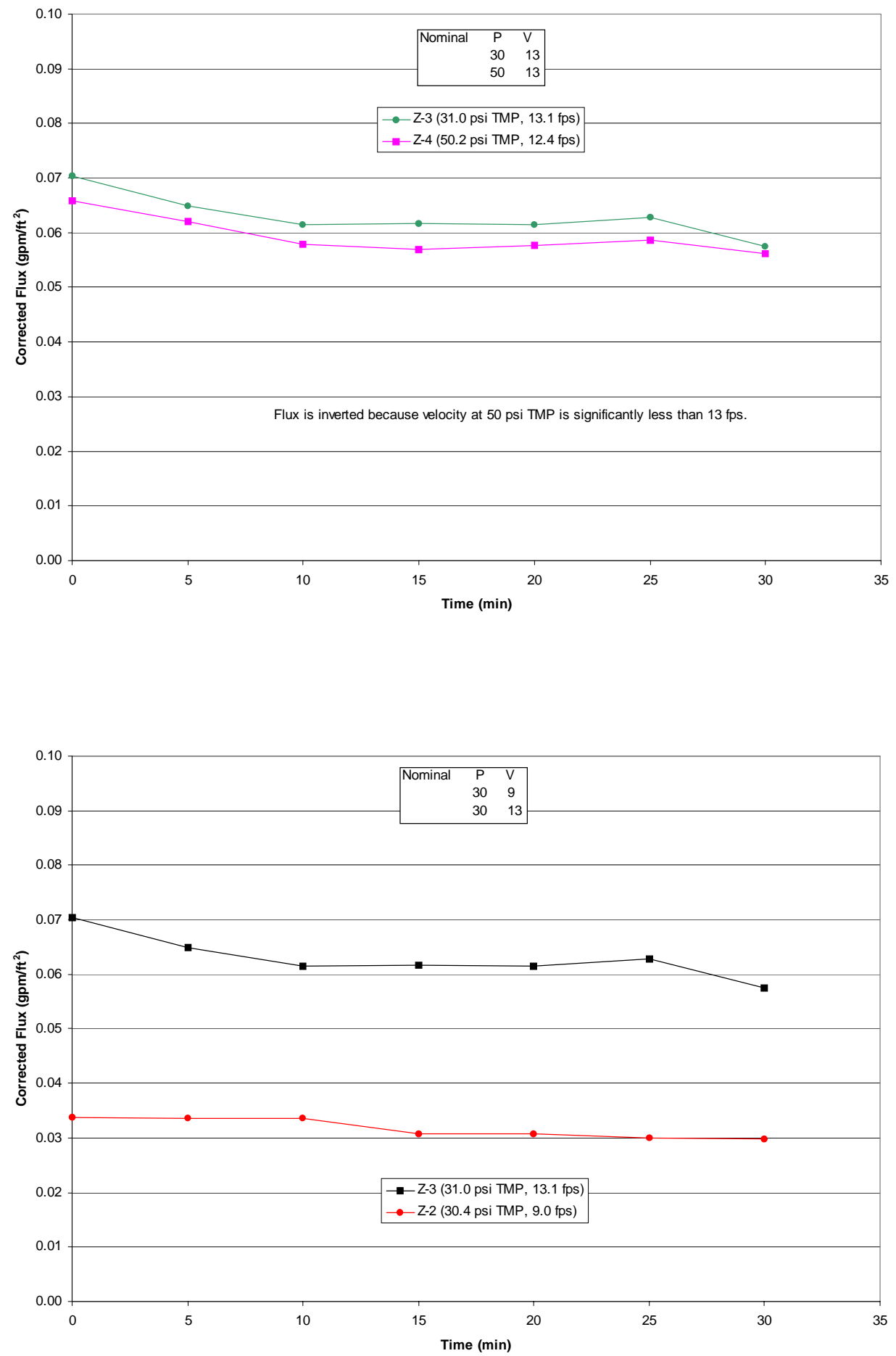

Page 56 of 82 
WSRC-TR-2002-00108, Rev. 0

SRT-RPP-2002-00041, Rev. 0
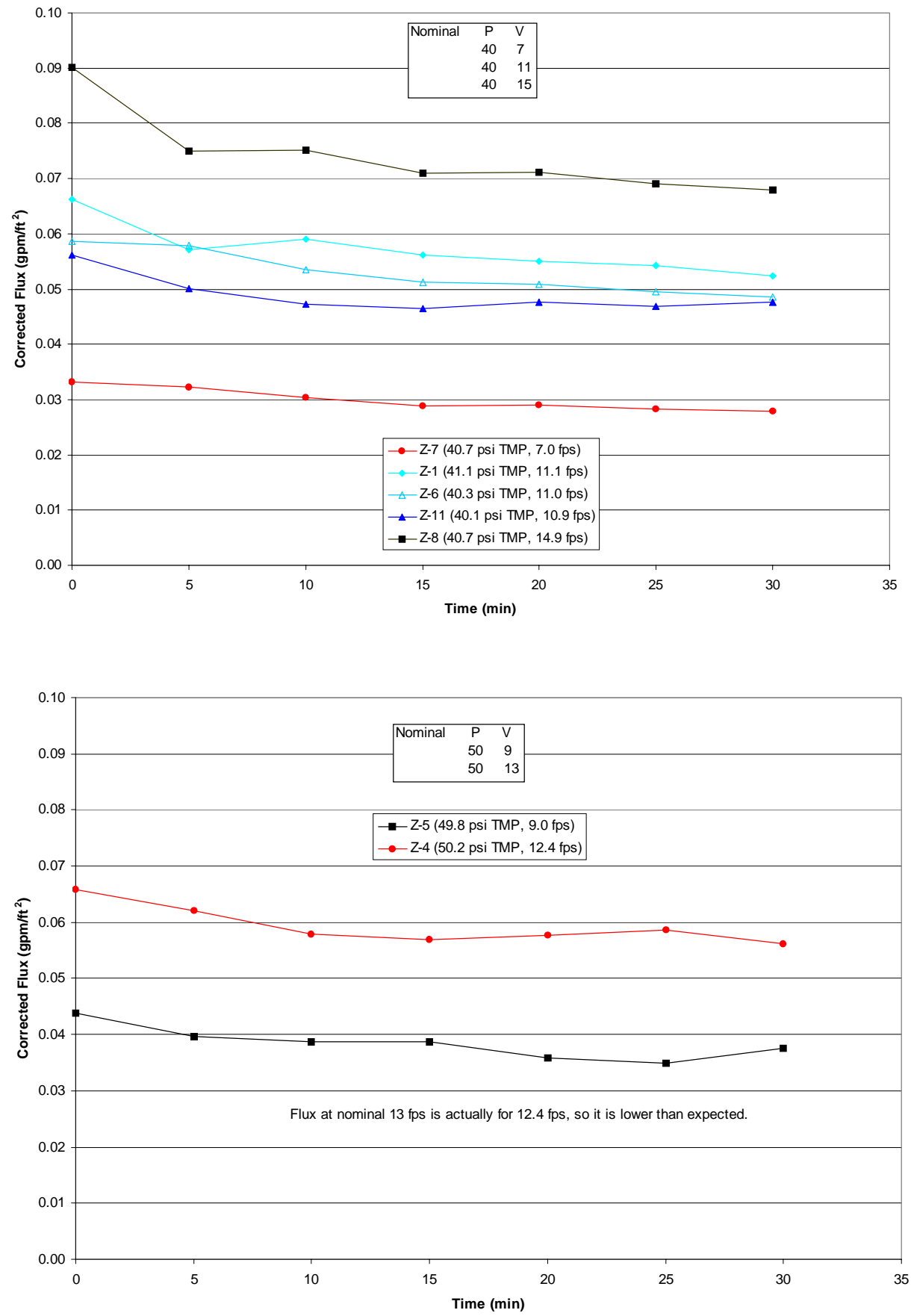
WSRC-TR-2002-00108, Rev. 0

SRT-RPP-2002-00041, Rev. 0
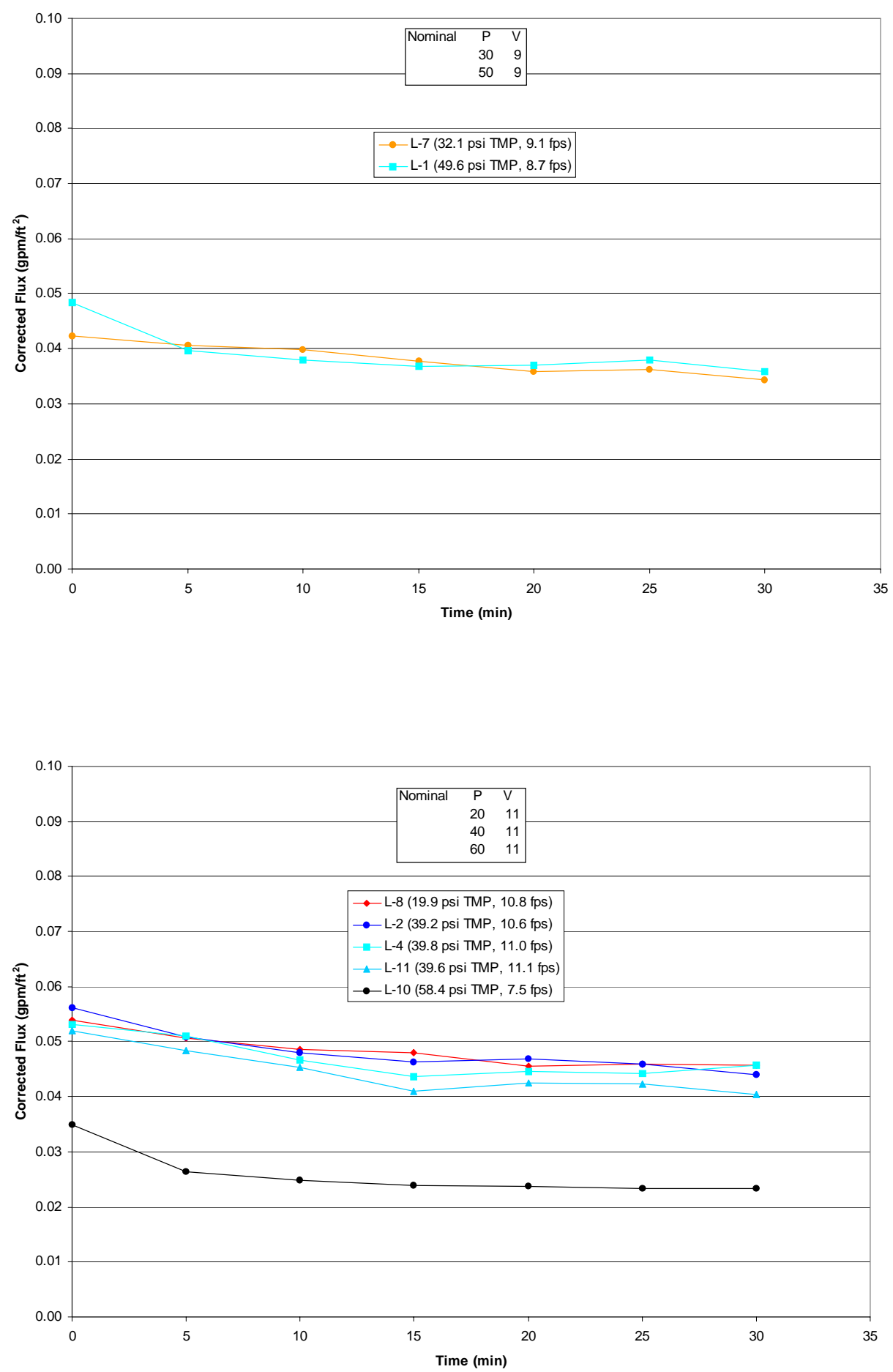
WSRC-TR-2002-00108, Rev. 0

SRT-RPP-2002-00041, Rev. 0
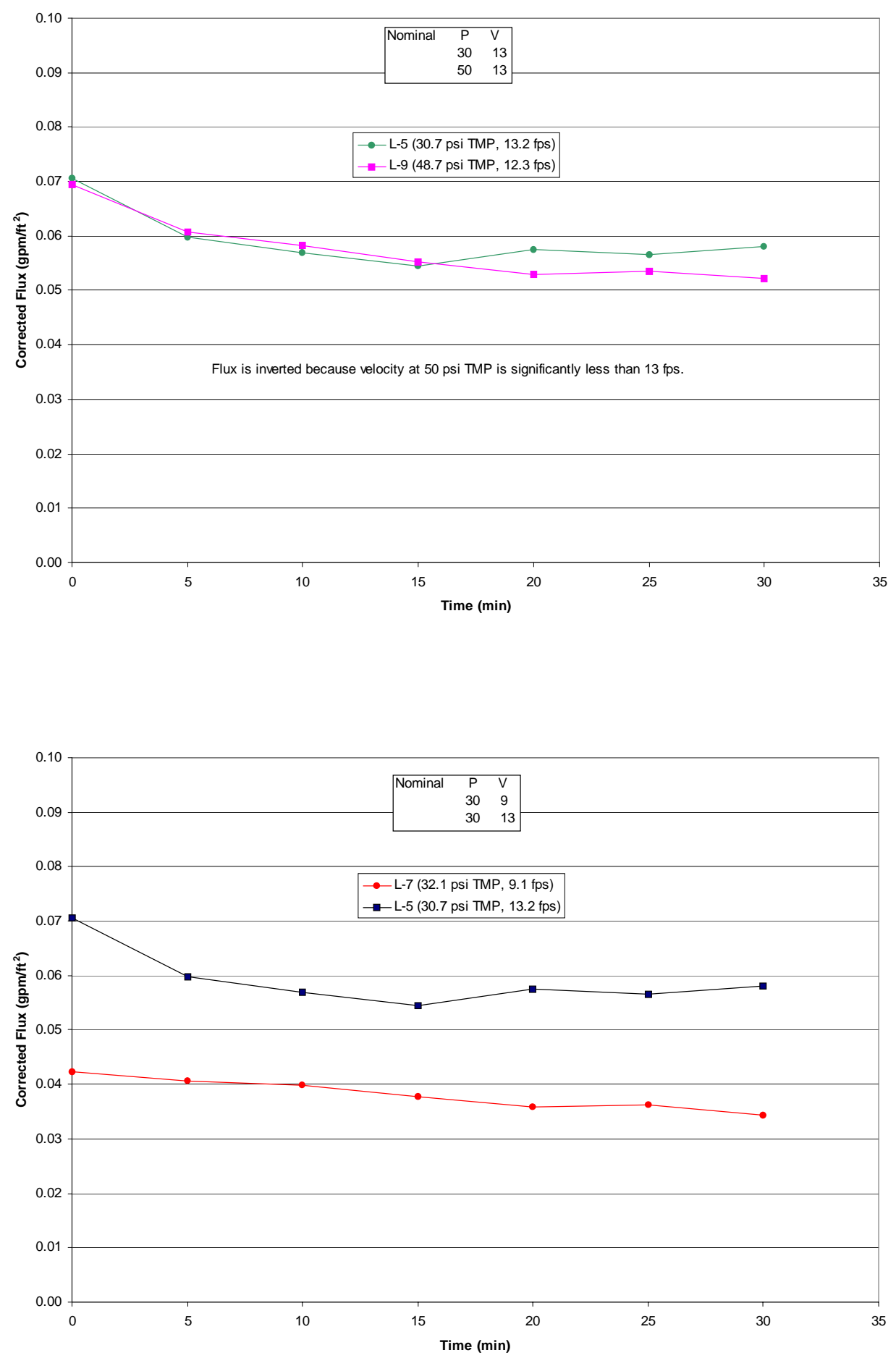
WSRC-TR-2002-00108, Rev. 0

SRT-RPP-2002-00041, Rev. 0
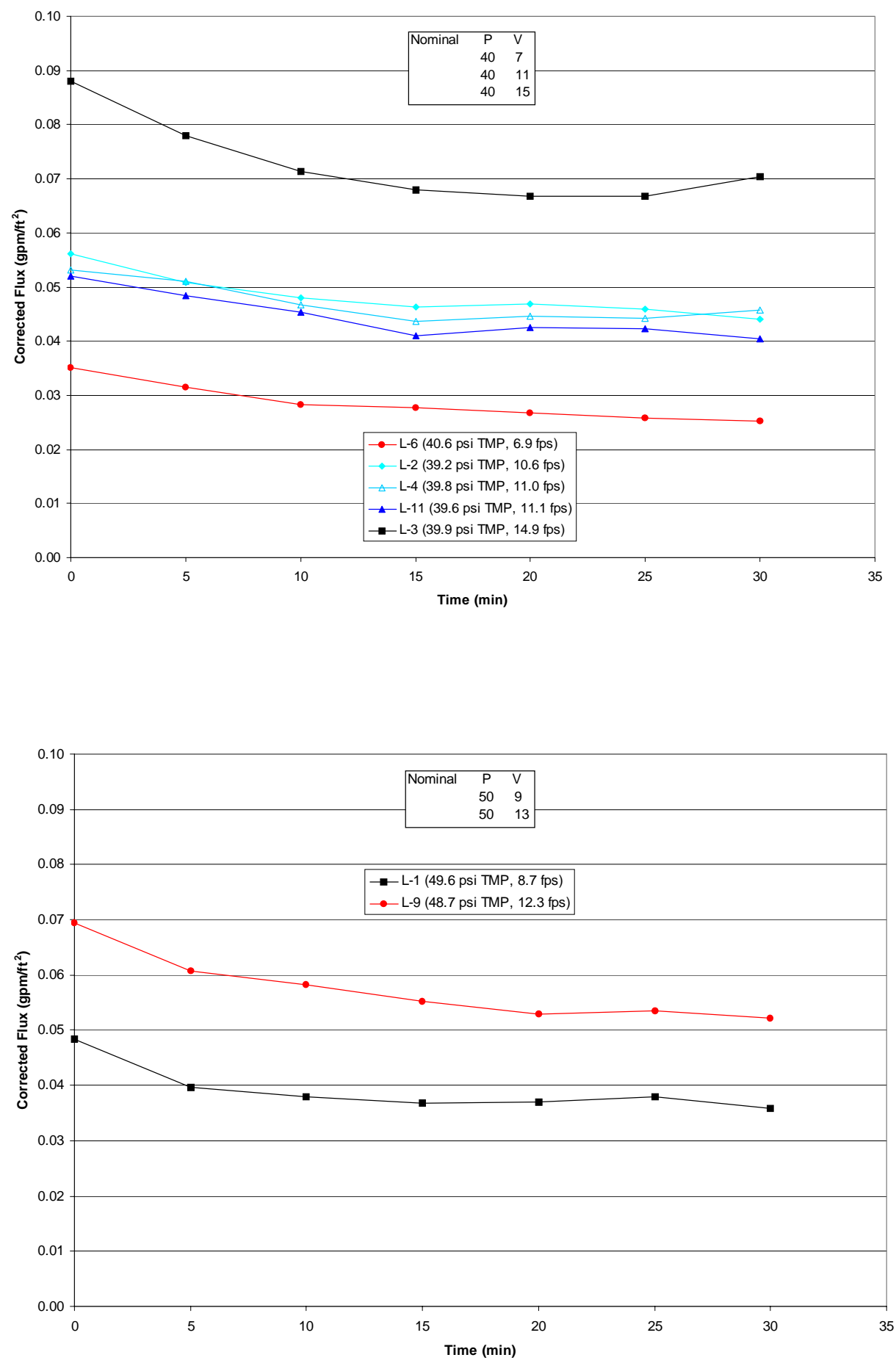
WSRC-TR-2002-00108, Rev. 0

SRT-RPP-2002-00041, Rev. 0
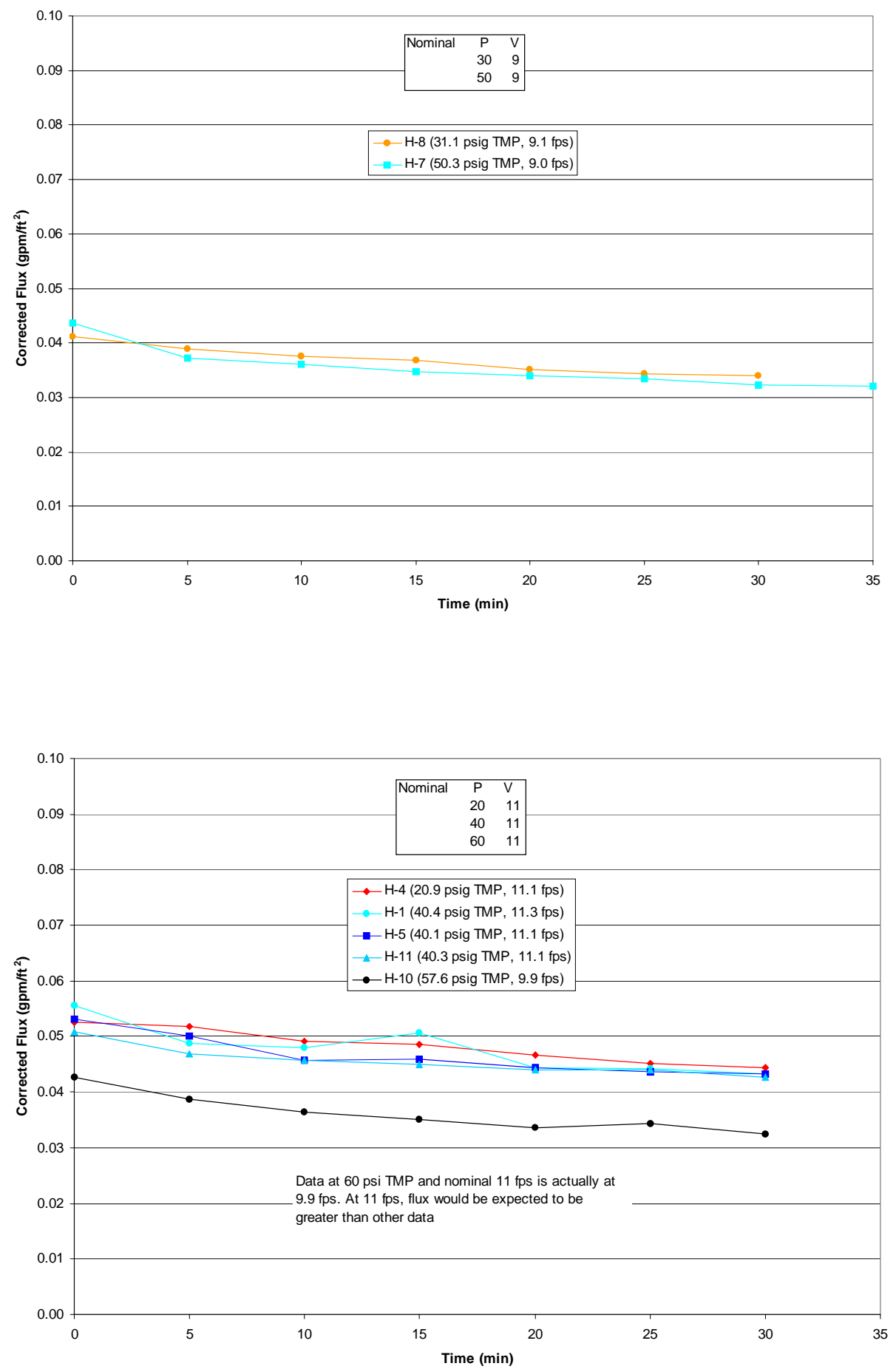
WSRC-TR-2002-00108, Rev. 0

SRT-RPP-2002-00041, Rev. 0
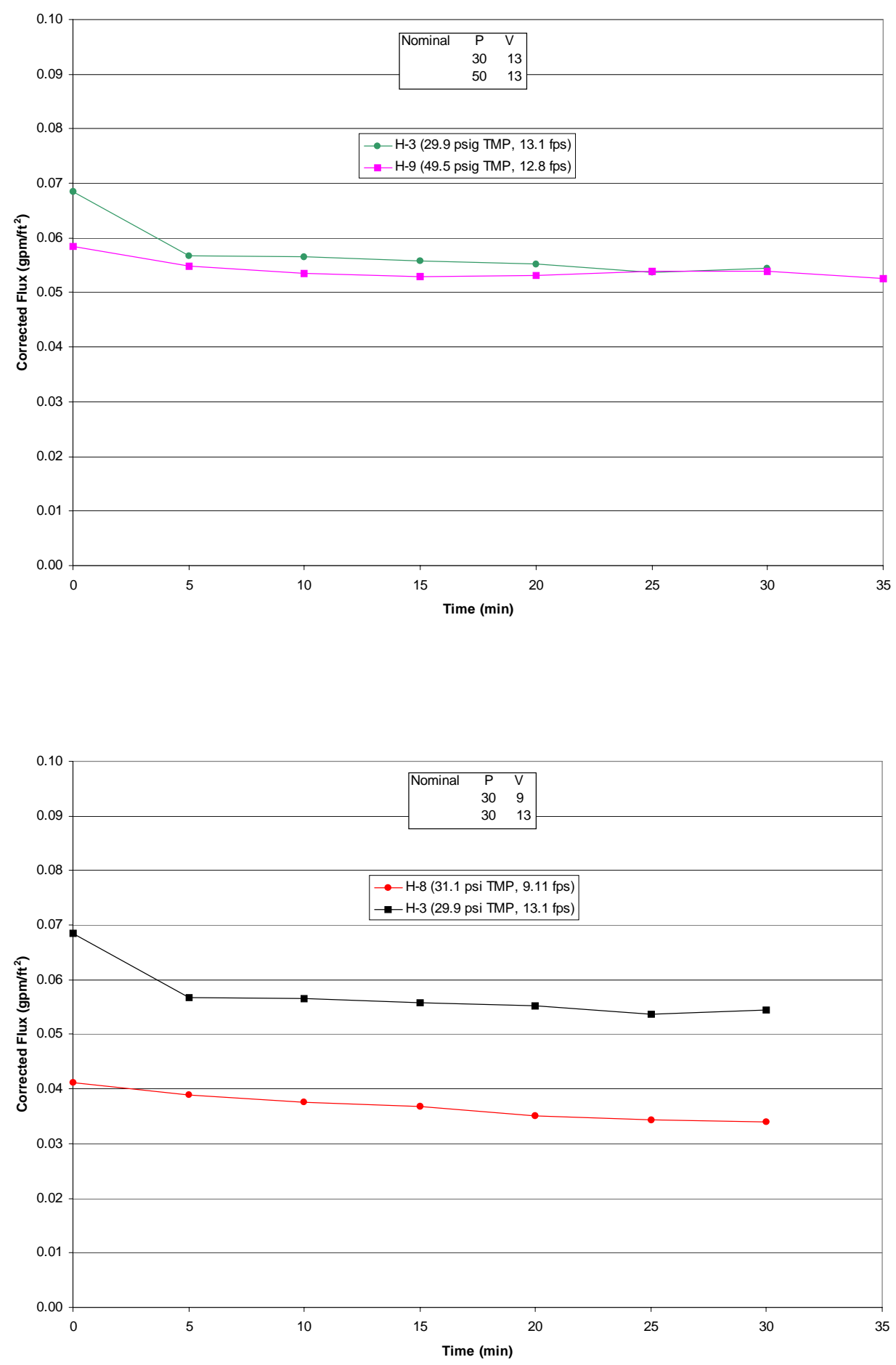
WSRC-TR-2002-00108, Rev. 0

SRT-RPP-2002-00041, Rev. 0
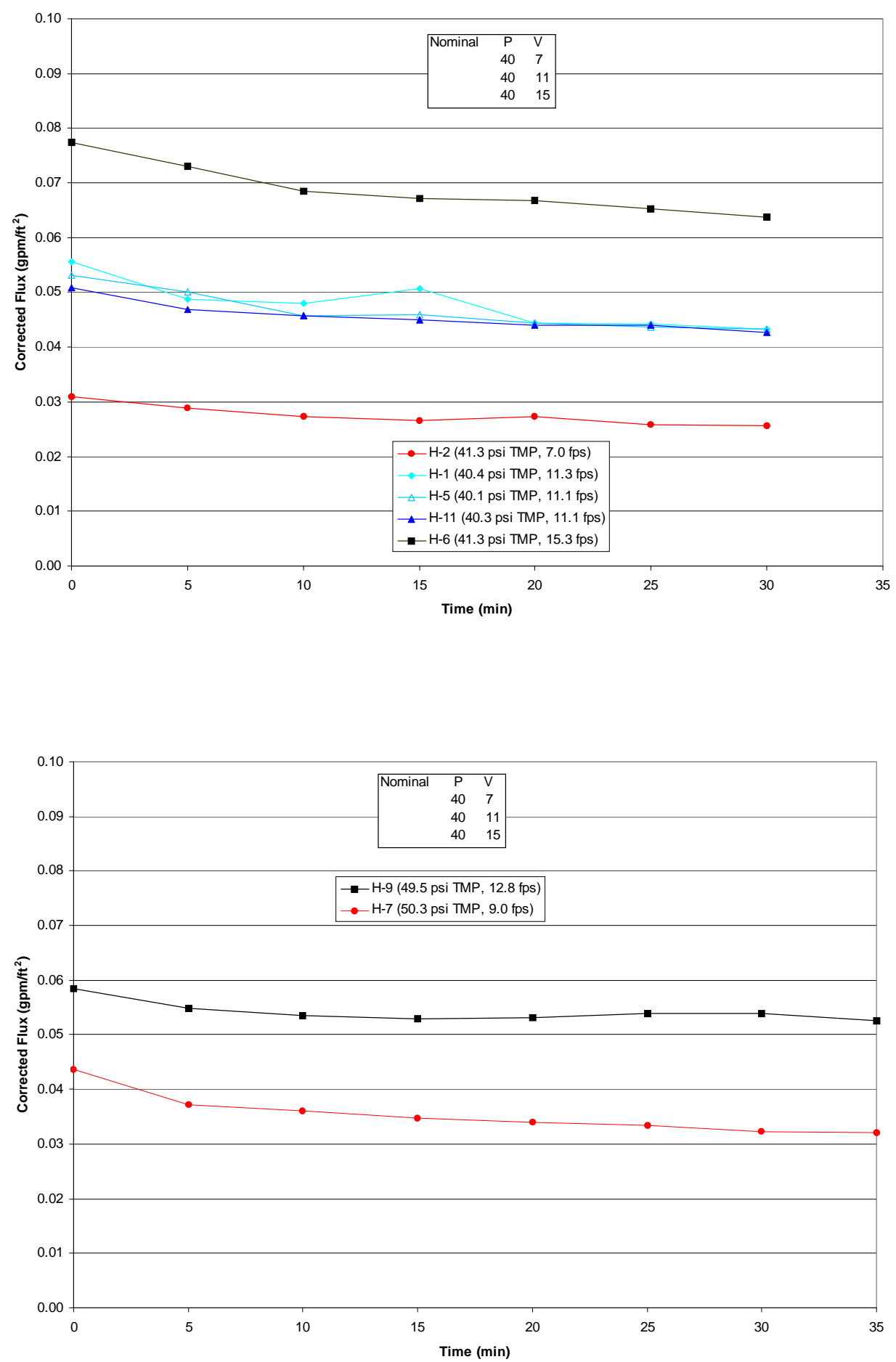
WSRC-TR-2002-00108, Rev. 0

SRT-RPP-2002-00041, Rev. 0
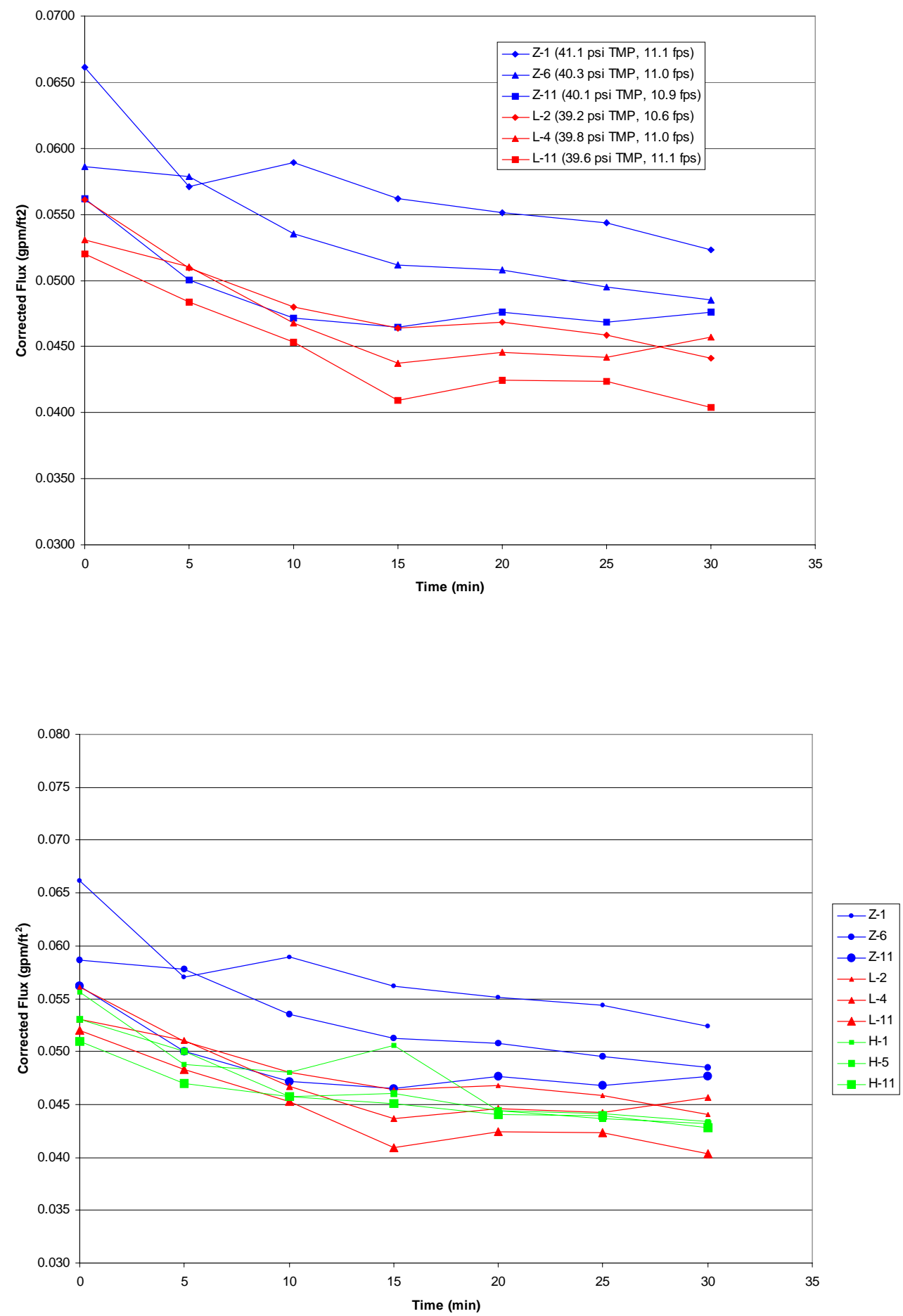
WSRC-TR-2002-00108, Rev. 0

SRT-RPP-2002-00041, Rev. 0

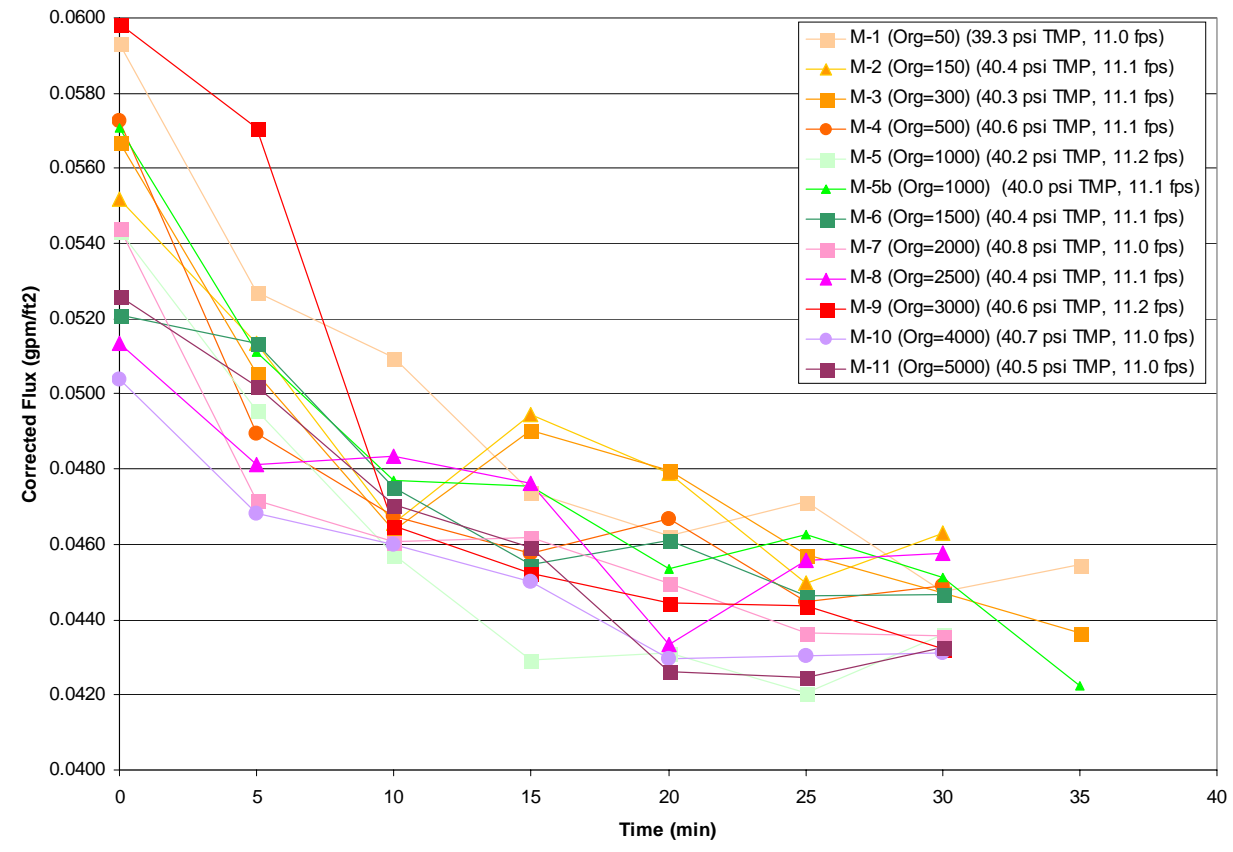




\subsection{Appendix - Curve Fits from JMP}

Fit of Flux $=\mathrm{aV}^{\mathrm{v}} \mathrm{P}^{\mathrm{p}} \mathrm{Q}^{\mathrm{q}} \mathrm{S}^{\mathrm{s}}\left(1-\mathrm{bt}_{\mathrm{adj}}\right)$

Flux $=$ gpm $/ \mathrm{ft}^{2}$

$\mathrm{V}=$ velocity (fps)

$\mathrm{P}=$ transmembrane pressure $(\mathrm{psi})$

$\mathrm{Q}=$ total organics $(\mathrm{TBP}+\mathrm{NPH})(\mathrm{mg} / \mathrm{L})$

$\mathrm{t}_{\mathrm{adj}}=$ cumulative run time (adjusted after $\left.\mathrm{t}=13.5\right)(\mathrm{hr})$

$\mathrm{S}=$ solids concentration (wt $\%)$

$\mathrm{a}, \mathrm{b}, \mathrm{p}, \mathrm{q}, \mathrm{s}$ are parameters

\section{Nonlinear Fit}

Converged in the Gradient

$\begin{array}{lll}\text { Criterion } & \text { Current } & \text { Stop Limit } \\ \text { Iteration } & 59 & 60 \\ \text { Shortening } & 0 & 15 \\ \text { Obj Change } & 8.212934 \mathrm{e}-13 & 0.0000001 \\ \text { Prm Change } & 0.0000079245 & 0.0000001 \\ \text { Gradient } & 1.988623 \mathrm{e}-16 & 0.000001\end{array}$

$\begin{array}{ll}\text { Parameter } & \text { Current Value } \\ \mathrm{a} & 0.005626668 \\ \mathrm{v} & 1.3465218598 \\ \mathrm{~b} & 0.0033701345 \\ \mathrm{q} & -0.010193617 \\ \mathrm{p} & -0.071298492 \\ \mathrm{~s} & -0.736696127\end{array}$

SSE 0.0002544523

$\mathrm{N} \quad 45$

Alpha 0.050

Convergence Criterion $\quad 0.00001$

Goal SSE for CL $\quad 0.0002811028$

\section{Solution}

\begin{tabular}{llll} 
SSE & DFE & MSE & RMSE \\
\hline 0.0002544523 & 39 & 0.0000065 & 0.0025543
\end{tabular}




\begin{tabular}{lllll} 
& & & $\begin{array}{l}\text { Lower } \\
\text { Confidence }\end{array}$ & $\begin{array}{l}\text { Upper } \\
\text { Confidence }\end{array}$ \\
Parameter & Estimate & $\begin{array}{l}\text { Approx. } \\
\text { Standard Error }\end{array}$ & Limit & Limit \\
\hline a & 0.005627 & 0.002171 & 0.002543 & 0.002543 \\
v & 1.3465 & 0.05437 & 1.2371 & 1.4569 \\
b & 0.003370 & 0.006026 & -0.009993 & 0.015354 \\
q & -0.01019 & 0.00946 & -0.02964 & 0.00979 \\
p & -0.07130 & 0.03728 & -0.14592 & 0.0049 \\
s & -0.7367 & 0.3231 & -1.3829 & -0.0905
\end{tabular}

\section{Correlation of Estimates}

\begin{tabular}{l|llllll} 
& $\mathrm{a}$ & $\mathrm{v}$ & $\mathrm{b}$ & $\mathrm{q}$ & $\mathrm{p}$ & $\mathrm{s}$ \\
\hline $\mathrm{a}$ & 1.0000 & -0.3946 & -0.1704 & 0.5026 & -0.2821 & -0.8592 \\
$\mathrm{v}$ & -0.3946 & 1.0000 & -0.1163 & -0.1184 & 0.0458 & 0.0298 \\
$\mathrm{~b}$ & -0.1704 & -0.1163 & 1.0000 & 0.6311 & -0.0420 & 0.3103 \\
$\mathrm{q}$ & 0.5026 & -0.1184 & 0.6311 & 1.0000 & 0.0219 & -0.4931 \\
$\mathrm{p}$ & -0.2821 & 0.0458 & -0.0420 & 0.0219 & 1.0000 & -0.0960 \\
$\mathrm{~s}$ & -0.8592 & 0.0298 & 0.3103 & -0.4931 & -0.0960 & 1.0000
\end{tabular}

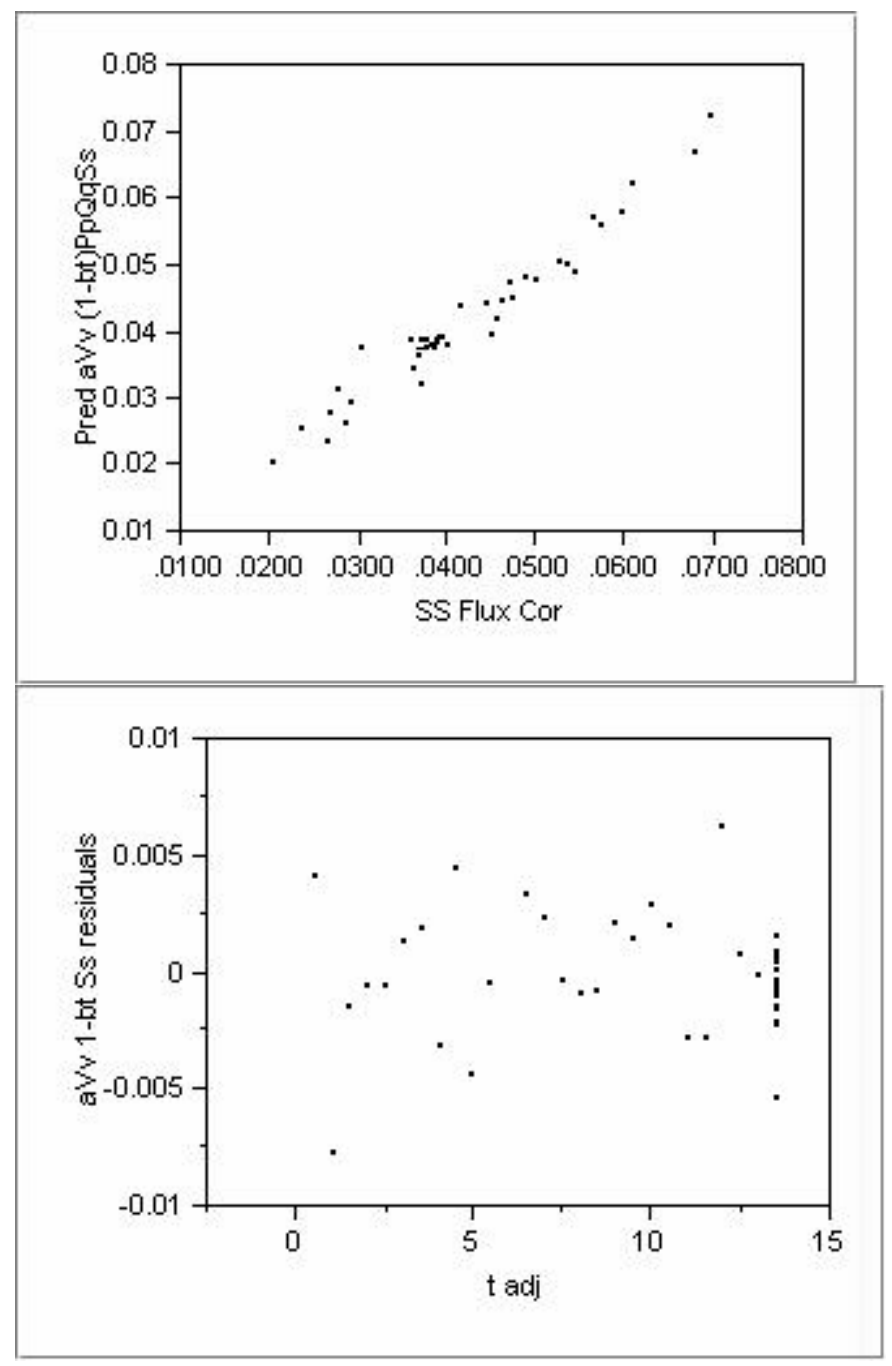


Fit of Flux $=\mathbf{a V}^{\mathrm{v}} \mathbf{P}^{\mathrm{p}} \mathbf{Q}^{\mathrm{q}}\left(\mathbf{1}-\mathbf{b t}_{\mathrm{adj}}\right)$

Flux $=\mathrm{gpm} / \mathrm{ft}^{2}$

$\mathrm{V}=$ velocity (fps)

$\mathrm{P}=$ transmembrane pressure $(\mathrm{psi})$

$\mathrm{Q}=$ total organics $(\mathrm{TBP}+\mathrm{NPH})(\mathrm{mg} / \mathrm{L})$

$\mathrm{t}_{\mathrm{adj}}=$ cumulative run time (adjusted after $\left.\mathrm{t}=13.5\right)(\mathrm{hr})$

$\mathrm{a}, \mathrm{b}, \mathrm{p}, \mathrm{q}, \mathrm{v}$ are parameters

Nonlinear Fit

Converged in the Gradient

\begin{tabular}{lll} 
Criterion & Current & Stop Limit \\
\hline Iteration & 4 & 60 \\
Shortening & 0 & 15 \\
Obj Change & 0.000308719 & 0.0000001 \\
Prm Change & 0.0646007448 & 0.0000001 \\
Gradient & $7.7701505 \mathrm{e}-8$ & 0.000001 \\
\multicolumn{3}{c}{} \\
Parameter & Current Value \\
\cline { 1 - 1 } a & 0.00264206 \\
v & 1.3503668344 \\
b & 0.0082221362 \\
q & -0.019724438 \\
p & -0.079136273 \\
SSE $\quad 0.0002869069$ \\
N 45
\end{tabular}

Alpha 0.050

Convergence Criterion $\quad 0.05$

Goal SSE for CL $\quad 0.000316161$

Solution

\begin{tabular}{llll} 
SSE & DFE & MSE & RMSE \\
\hline 0.0002869069 & 40 & 0.0000072 & 0.0026782
\end{tabular}




\begin{tabular}{|c|c|c|c|c|}
\hline Parameter & Estimate & $\begin{array}{l}\text { Approx. } \\
\text { Standard Error }\end{array}$ & $\begin{array}{l}\text { Lower } \\
\text { Confidence } \\
\text { Limit }\end{array}$ & $\begin{array}{l}\text { Upper } \\
\text { Confidence } \\
\text { Limit }\end{array}$ \\
\hline $\mathrm{a}$ & 0.002642 & 0.000547 & 0.001728 & 0.004016 \\
\hline $\mathrm{V}$ & 1.350 & 0.057 & 1.234 & 1.467 \\
\hline b & 0.008222 & 0.005655 & -0.004988 & 0.019929 \\
\hline$q$ & -0.01972 & 0.00877 & -0.03813 & 0.00058 \\
\hline $\mathrm{p}$ & -0.07914 & 0.03911 & -0.15746 & 0.00129 \\
\hline
\end{tabular}

Correlation of Estimates

\begin{tabular}{l|lllll} 
& $\mathrm{a}$ & $\mathrm{v}$ & $\mathrm{b}$ & $\mathrm{q}$ & $\mathrm{p}$ \\
\hline $\mathrm{a}$ & 1.0000 & -0.7219 & 0.1902 & 0.1711 & -0.7145 \\
$\mathrm{v}$ & -0.7219 & 1.0000 & -0.1340 & -0.1209 & 0.0461 \\
$\mathrm{~b}$ & 0.1902 & -0.1340 & 1.0000 & 0.9503 & -0.0074 \\
$\mathrm{q}$ & 0.1711 & -0.1209 & 0.9503 & 1.0000 & -0.0244 \\
$\mathrm{p}$ & -0.7145 & 0.0461 & -0.0074 & -0.0244 & 1.0000
\end{tabular}

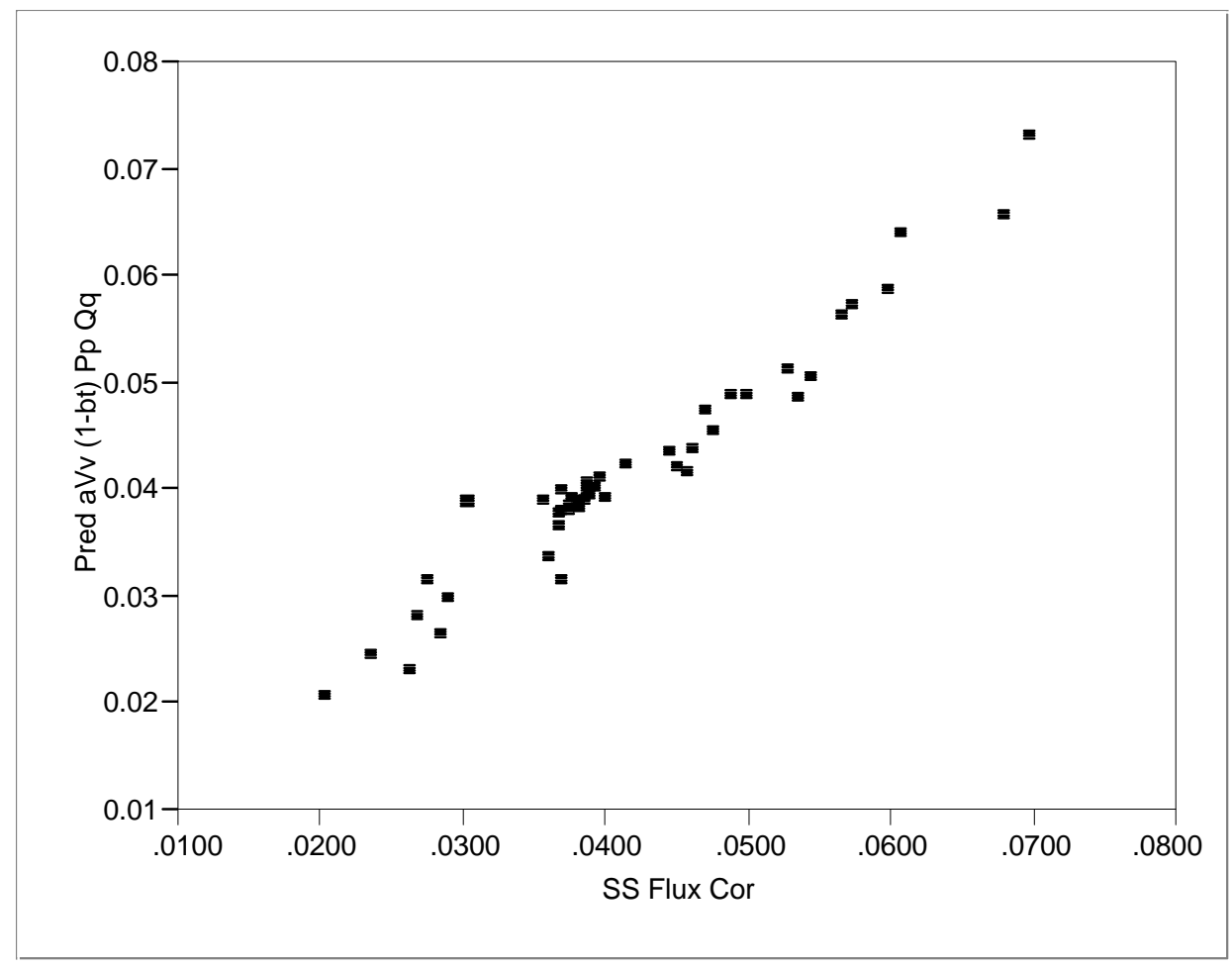


Fit of Flux $=\mathbf{a V}^{\mathrm{v}} \mathbf{P}^{\mathrm{p}} \mathbf{Q}^{\mathrm{q}}\left(\mathbf{1}-\mathbf{b t}_{\mathrm{adj}}\right)$

Flux $=\mathrm{gpm} / \mathrm{ft}^{2}$

$\mathrm{V}=$ velocity (fps)

$\mathrm{P}=$ transmembrane pressure $(\mathrm{psi})$

$\mathrm{Q}=$ total organics $(\mathrm{TBP}+\mathrm{NPH})(\mathrm{mg} / \mathrm{L})$

$\mathrm{t}_{\mathrm{adj}}=$ cumulative run time (adjusted after $\left.\mathrm{t}=13.5\right)(\mathrm{hr})$

$\mathrm{a}, \mathrm{b}, \mathrm{p}, \mathrm{q}, \mathrm{v}$ are parameters

Nonlinear Fit

Converged in the Gradient

\begin{tabular}{lll} 
Criterion & Current & Stop Limit \\
\hline Iteration & 4 & 60 \\
Shortening & 0 & 15 \\
Obj Change & 0.000308719 & 0.0000001 \\
Prm Change & 0.0646007448 & 0.0000001 \\
Gradient & $7.7701505 \mathrm{e}-8$ & 0.000001 \\
\multicolumn{3}{c}{} \\
Parameter & Current Value \\
\cline { 1 - 1 } a & 0.00264206 \\
v & 1.3503668344 \\
b & 0.0082221362 \\
q & -0.019724438 \\
p & -0.079136273 \\
SSE $\quad 0.0002869069$ \\
N 45
\end{tabular}

Alpha 0.050

Convergence Criterion $\quad 0.05$

Goal SSE for CL $\quad 0.000316161$

Solution

\begin{tabular}{llll} 
SSE & DFE & MSE & RMSE \\
\hline 0.0002869069 & 40 & 0.0000072 & 0.0026782
\end{tabular}




\begin{tabular}{l|llll} 
& & & $\begin{array}{l}\text { Lower } \\
\text { Confidence }\end{array}$ & $\begin{array}{l}\text { Upper } \\
\text { Confidence } \\
\text { Approx. }\end{array}$ \\
Parameter & Estimate & $\begin{array}{l}\text { Standard Error } \\
\text { Limit }\end{array}$ & Limit \\
\hline a & 0.002642 & 0.000547 & 0.001728 & 0.004016 \\
v & 1.350 & 0.057 & 1.234 & 1.467 \\
b & 0.008222 & 0.005655 & -0.004988 & 0.019929 \\
q & -0.01972 & 0.00877 & -0.03813 & 0.00058 \\
p & -0.07914 & 0.03911 & -0.15746 & 0.00129
\end{tabular}

Correlation of Estimates

\begin{tabular}{l|lllll} 
& $\mathrm{a}$ & $\mathrm{v}$ & $\mathrm{b}$ & $\mathrm{q}$ & $\mathrm{p}$ \\
\hline $\mathrm{a}$ & 1.0000 & -0.7219 & 0.1902 & 0.1711 & -0.7145 \\
$\mathrm{v}$ & -0.7219 & 1.0000 & -0.1340 & -0.1209 & 0.0461 \\
$\mathrm{~b}$ & 0.1902 & -0.1340 & 1.0000 & 0.9503 & -0.0074 \\
$\mathrm{q}$ & 0.1711 & -0.1209 & 0.9503 & 1.0000 & -0.0244 \\
$\mathrm{p}$ & -0.7145 & 0.0461 & -0.0074 & -0.0244 & 1.0000
\end{tabular}

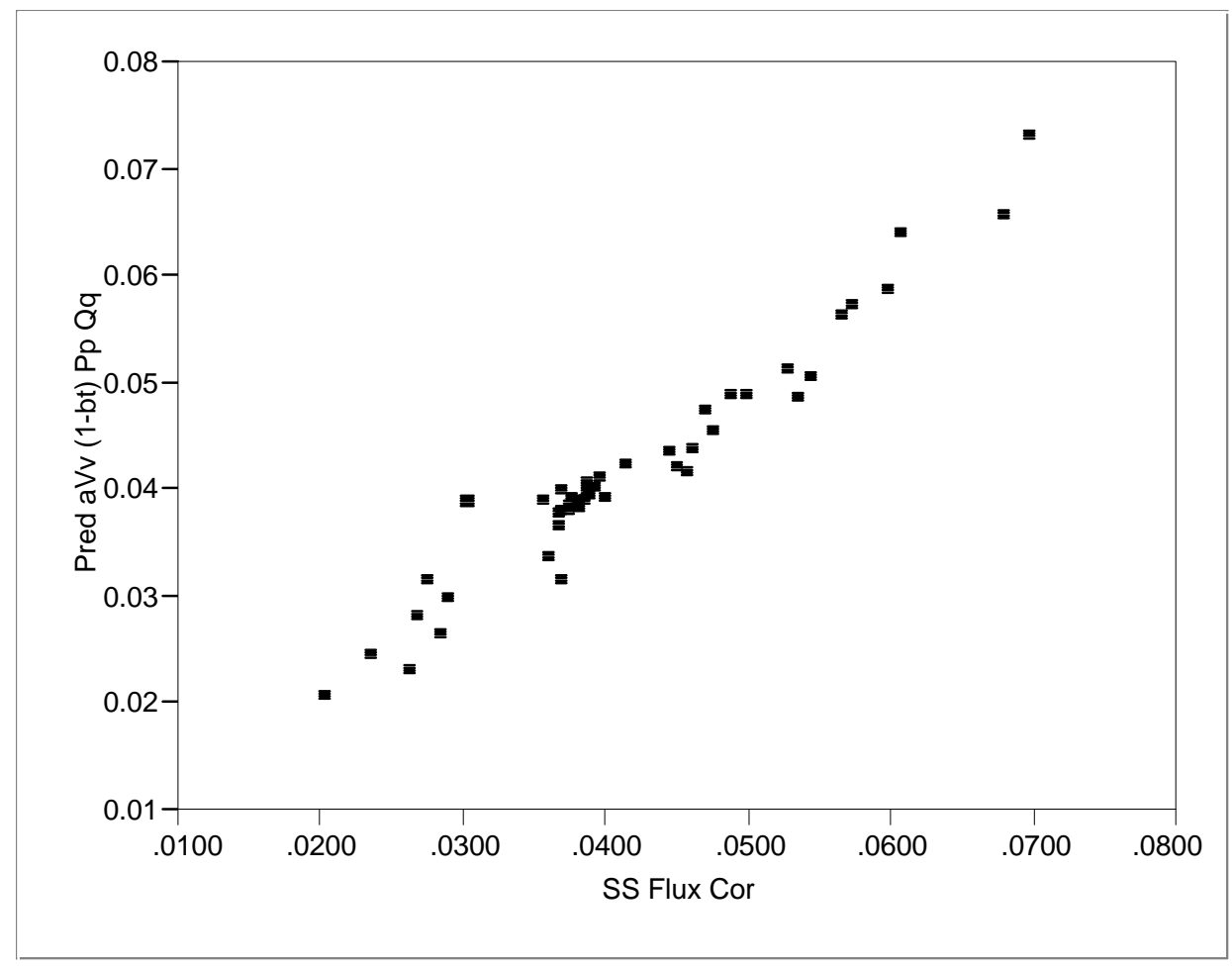


Fit of Flux $=a V^{\mathbf{v}} Q^{\mathbf{q}}\left(\mathbf{1}-\mathbf{b t}_{\mathbf{a d j}}\right)$

Flux $=\mathrm{gpm} / \mathrm{ft}^{2}$

$\mathrm{V}=$ velocity (fps)

$\mathrm{Q}=$ total organics $(\mathrm{TBP}+\mathrm{NPH})(\mathrm{mg} / \mathrm{L})$

$\mathrm{t}_{\mathrm{adj}}=$ cumulative run time (adjusted after $\left.\mathrm{t}=13.5\right)(\mathrm{hr})$

$\mathrm{a}, \mathrm{b}, \mathrm{q}, \mathrm{v}$ are parameters

Nonlinear Fit

Converged in the Gradient

$\begin{array}{ll}\text { Criterion } & \text { Current } \\ \text { Iteration } & 3 \\ \text { Shortening } & 0 \\ \text { Obj Change } & 0.0003080764 \\ \text { Prm Change } & 0.0667741471 \\ \text { Gradient } & 8.4865869 \mathrm{e}-8 \\ & \\ \text { Parameter } & \text { Current Value } \\ \text { a } & 0.0019529218 \\ \text { v } & 1.3566523696 \\ \text { b } & 0.0084367207 \\ \text { q } & -0.019681765\end{array}$

Stop Limit

60

15

0.0000001

0.0000001

0.000001

SSE $\quad 0.0003152431$

$\mathrm{N} \quad 45$

Alpha 0.050

Convergence Criterion $\quad 0.05$

Goal SSE for CL $\quad 0.0003465571$

Solution

\begin{tabular}{llll} 
SSE & DFE & MSE & RMSE \\
\hline 0.0003152431 & 41 & 0.0000077 & 0.0027729
\end{tabular}




$\begin{array}{lllll} & & & \text { Lower } & \text { Upper } \\ \text { Parameter } & \text { Estimate } & \begin{array}{l}\text { Approx. } \\ \text { Standard Error }\end{array} & \text { Limit } & \text { Limit } \\ \text { a } & 0.001953 & 0.000291 & 0.001438 & 0.00264 \\ \text { v } & 1.357 & 0.059 & 1.238 & 1.477 \\ \text { b } & 0.008437 & 0.005831 & -0.005246 & 0.020509 \\ \text { q } & -0.01968 & 0.00907 & -0.03875 & 0.00143\end{array}$

Correlation of Estimates

\begin{tabular}{l|llll} 
& $\mathrm{a}$ & $\mathrm{v}$ & $\mathrm{b}$ & $\mathrm{q}$ \\
\hline $\mathrm{a}$ & 1.0000 & -0.9858 & 0.2638 & 0.2191 \\
$\mathrm{v}$ & -0.9858 & 1.0000 & -0.1333 & -0.1195 \\
$\mathrm{~b}$ & 0.2638 & -0.1333 & 1.0000 & 0.9504 \\
$\mathrm{q}$ & 0.2191 & -0.1195 & 0.9504 & 1.0000
\end{tabular}

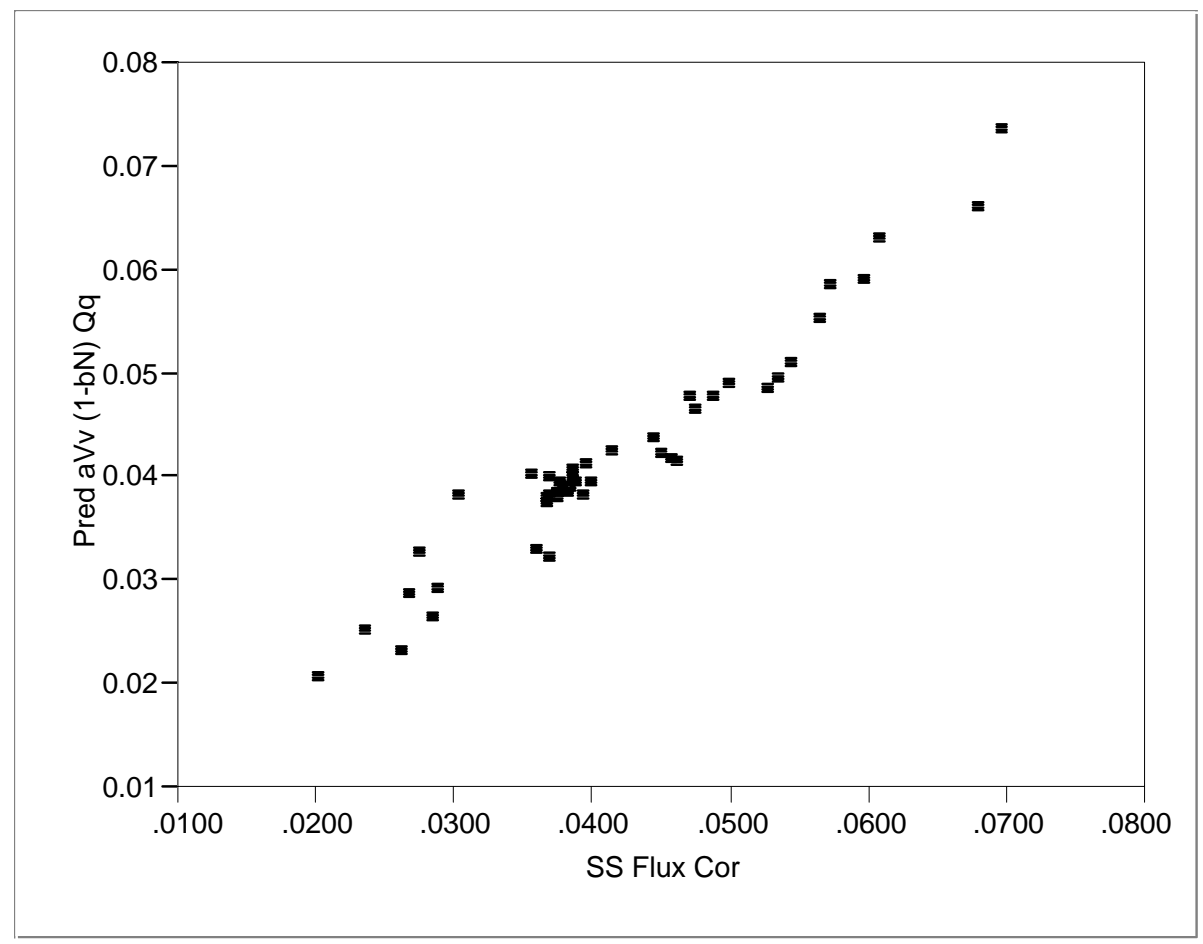


Fit of Flux $=\mathrm{aV}^{\mathrm{v}} \mathrm{S}^{\mathrm{s}}\left(1-\mathrm{bt}_{\mathrm{adj}}\right)$

Flux $=\mathrm{gpm} / \mathrm{ft}^{2}$

$\mathrm{V}=$ velocity (fps)

$\mathrm{P}=$ transmembrane pressure $(\mathrm{psi})$

$\mathrm{Q}=$ total organics $(\mathrm{TBP}+\mathrm{NPH})(\mathrm{mg} / \mathrm{L})$

$\mathrm{t}_{\mathrm{adj}}=$ cumulative run time (adjusted after $\left.\mathrm{t}=13.5\right)(\mathrm{hr})$

$\mathrm{a}, \mathrm{b}, \mathrm{s}, \mathrm{v}$ are parameters

Converged in the Gradient

$\begin{array}{lll}\text { Criterion } & \text { Current } & \text { Stop Limit } \\ \text { Iteration } & 59 & 60 \\ \text { Shortening } & 0 & 15 \\ \text { Obj Change } & 3.8329933 \mathrm{e}-7 & 0.0000001 \\ \text { Prm Change } & 0.0001371318 & 0.0000001 \\ \text { Gradient } & 1.089313 \mathrm{e}-10 & 0.000001 \\ \text { Parameter } & \text { Current Value } & \\ \text { a } & 0.0054779622 & \\ \text { v } & 1.3458730305 \\ \text { b } & 0.007057525 \\ \text { s } & -0.942319127 \\ \text { Lock } & \\ \text { SSE } \quad 0.0002839426 & \\ \text { N } \quad 45 & \\ \text { Alpha } & 0.050 & \\ \text { Convergence Criterion } & 0.00001 \\ \text { Goal SSE for CL } & 0.0003121475\end{array}$

Solution

SSE DFE MSE RMSE

$\begin{array}{llll}0.0002839426 & 41 & 0.0000069 & 0.0026316\end{array}$

\begin{tabular}{lllll}
\hline & & & Lower & Upper \\
Parameter & Estimate & Standidence & $\begin{array}{l}\text { Confidence } \\
\text { Simit }\end{array}$ \\
\hline a & 0.005478 & 0.001809 & 0.001860 & 0.009096 \\
v & 1.3459 & 0.0551 & 1.2354 & 1.4571 \\
b & 0.007058 & 0.004624 & -0.002942 & 0.016239 \\
s & -0.9423 & 0.2959 & -1.5341 & -0.3505
\end{tabular}


Correlation of Estimates

$\begin{array}{lllll} & \mathrm{a} & \mathrm{v} & \mathrm{b} & \mathrm{s} \\ \mathrm{a} & 1.0000 & -0.3827 & -0.8121 & -0.9096 \\ \mathrm{v} & -0.3827 & 1.0000 & -0.0522 & -0.0313 \\ \mathrm{~b} & -0.8121 & -0.0522 & 1.0000 & 0.9247 \\ \mathrm{~s} & -0.9096 & -0.0313 & 0.9247 & 1.0000\end{array}$

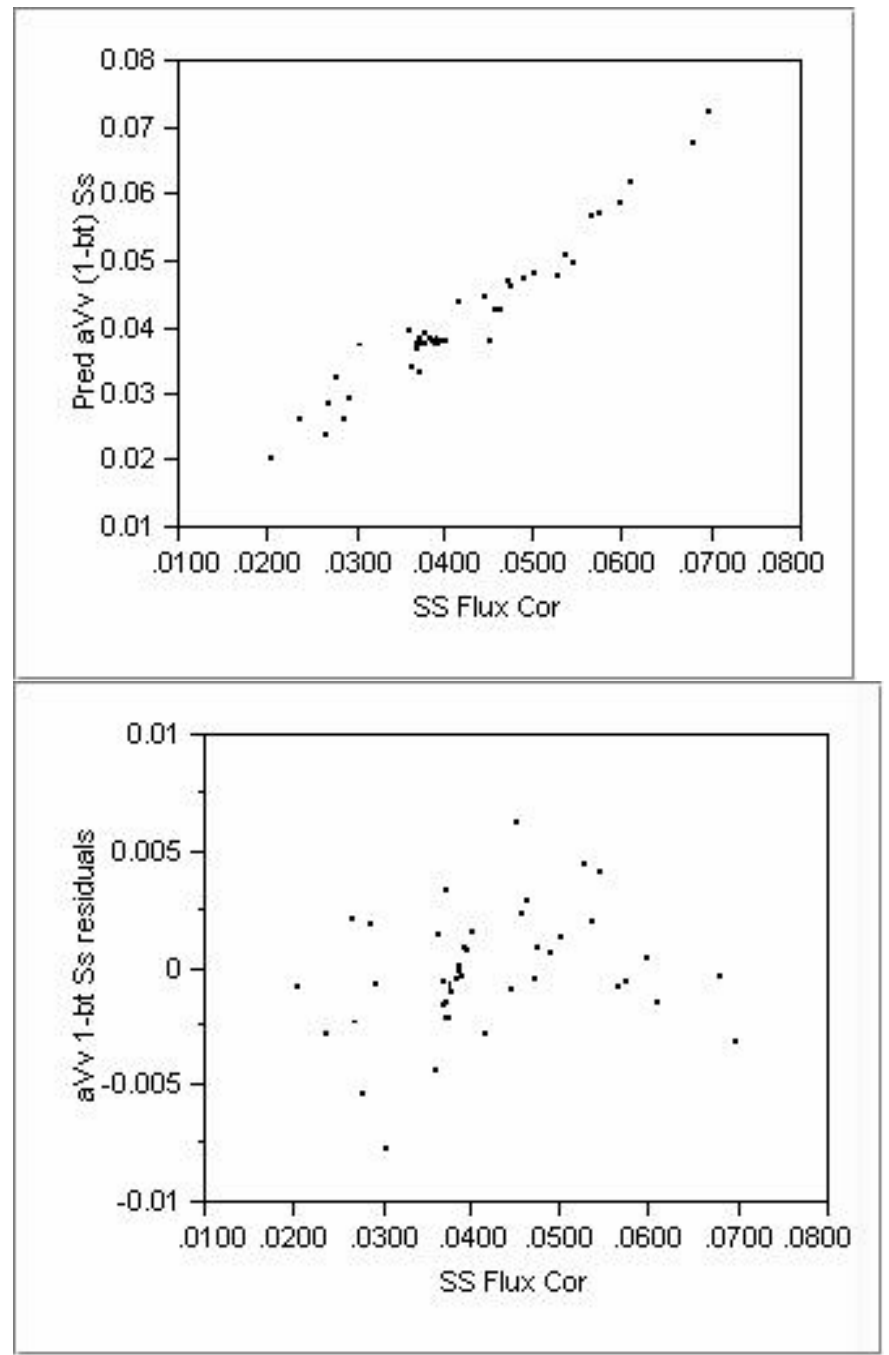


WSRC-TR-2002-00108, Rev. 0

SRT-RPP-2002-00041, Rev. 0

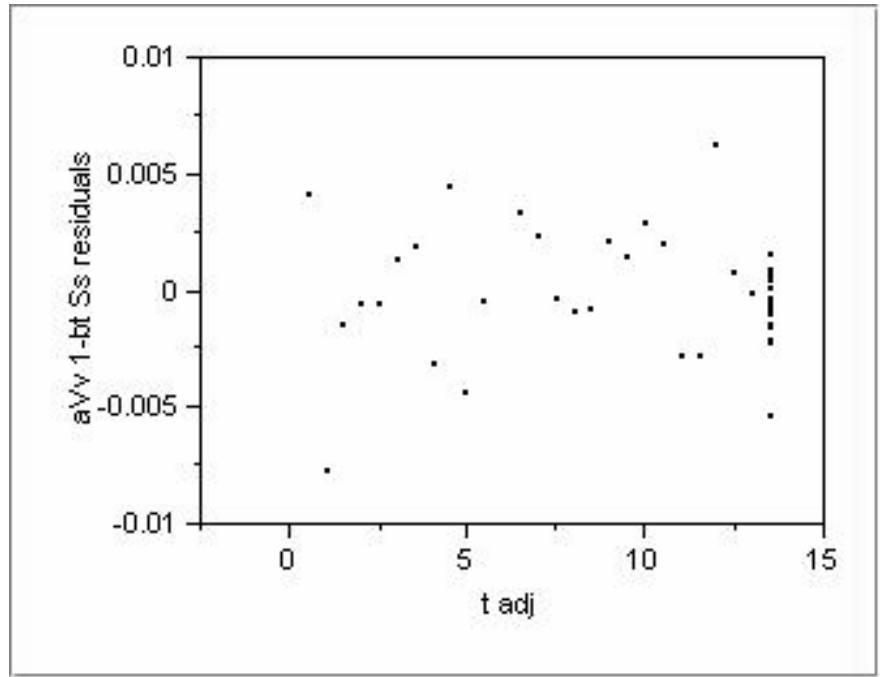

Page 76 of 82 
Fit of Flux $=\mathrm{aV}^{\mathrm{v}} \mathrm{S}^{\mathrm{S}}$

Flux $=\mathrm{gpm} / \mathrm{ft}^{2}$

$\mathrm{V}=$ velocity (fps)

$\mathrm{S}=$ solids concentration

$\mathrm{a}, \mathrm{v}, \mathrm{s}$ are parameters

\section{Nonlinear Fit}

Converged in the Gradient

$\begin{array}{lll}\text { Criterion } & \text { Current } & \text { Stop Limit } \\ \text { Iteration } & 4 & 60 \\ \text { Shortening } & 0 & 15 \\ \text { Obj Change } & 0.0013144702 & 0.0000001 \\ \text { Prm Change } & 0.0009129883 & 0.0000001 \\ \text { Gradient } & 3.9218594 \mathrm{e}-7 & 0.000001\end{array}$

$\begin{array}{ll}\text { Parameter } & \text { Current Value } \\ \mathrm{a} & 0.0080168667 \\ \mathrm{v} & 1.3501400332 \\ \mathrm{~S} & -1.333106672\end{array}$

SSE $\quad 0.0002983598$

$\mathrm{N} \quad 45$

Alpha 0.050

Convergence Criterion $\quad 0.00001$

Goal SSE for CL $\quad 0.0003272513$

\section{Solution}

$\begin{array}{llll}\text { SSE } & \text { DFE } & \text { MSE } & \text { RMSE } \\ 0.0002983598 & 42 & 0.0000071 & 0.0026653\end{array}$

\begin{tabular}{|c|c|c|c|c|}
\hline Parameter & Estimate & $\begin{array}{l}\text { Approx. } \\
\text { Standard Error }\end{array}$ & $\begin{array}{l}\text { Lower } \\
\text { Confidence } \\
\text { Limit }\end{array}$ & $\begin{array}{l}\text { Upper } \\
\text { Confidence } \\
\text { Limit }\end{array}$ \\
\hline $\mathrm{a}$ & 0.008017 & 0.001568 & 0.005391 & 0.010643 \\
\hline $\mathrm{V}$ & 1.3501 & 0.0558 & 1.2388 & 1.4624 \\
\hline s & -1.3331 & 0.1148 & -1.5648 & -1.1023 \\
\hline
\end{tabular}

\section{Correlation of Estimates}

$\begin{array}{cccc} & \mathrm{a} & \mathrm{V} & \mathrm{s} \\ \mathrm{a} & 1.0000 & -0.7276 & -0.7156 \\ \mathrm{v} & -0.7276 & 1.0000 & 0.0438 \\ \mathrm{~s} & -0.7156 & 0.0438 & 1.0000\end{array}$


WSRC-TR-2002-00108, Rev. 0

SRT-RPP-2002-00041, Rev. 0
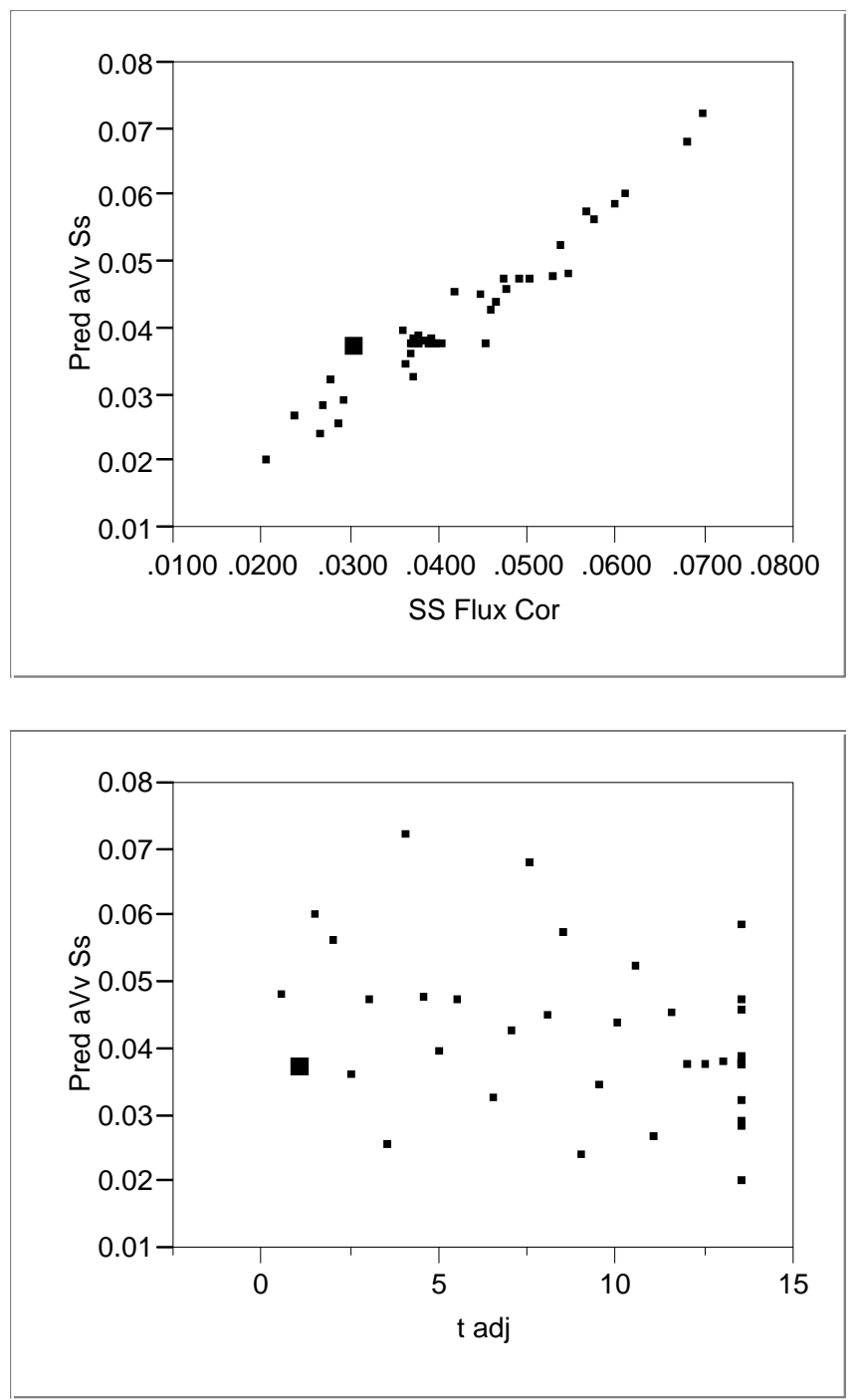

Page 78 of 82 
Fit of Flux $=\mathbf{a V}^{\mathbf{v}}\left(\mathbf{1}-\mathbf{b t}_{\mathbf{a d j}}\right)$

Flux $=\mathrm{gpm} / \mathrm{ft}^{2}$

$\mathrm{V}=$ velocity (fps)

$\mathrm{t}_{\mathrm{adj}}=$ cumulative run time (adjusted after $\left.\mathrm{t}=13.5\right)(\mathrm{hr})$

$\mathrm{a}, \mathrm{b}, \mathrm{v}$ are parameters

Nonlinear Fit

Converged in the Gradient

$\begin{array}{lll}\text { Criterion } & \text { Current } & \text { Stop Limit } \\ \text { Iteration } & 2 & 60 \\ \text { Shortening } & 0 & 15 \\ \text { Obj Change } & 0.0000272661 & 0.0000001 \\ \text { Prm Change } & 0.0050122417 & 0.0000001 \\ \text { Gradient } & 9.3709483 \mathrm{e}-9 & 0.000001\end{array}$

Parameter Current Value

a $\quad 0.0020910329$

v $\quad 1.3418623025$

b $\quad 0.0194210721$

SSE $\quad 0.0003425838$

$\mathrm{N} \quad 45$

Alpha 0.050

Convergence Criterion $\quad 0.05$

Goal SSE for CL $\quad 0.0003757578$

Solution

\begin{tabular}{llll} 
SSE & DFE & MSE & RMSE \\
\hline 0.0003425838 & 42 & 0.0000082 & 0.002856
\end{tabular}

\begin{tabular}{|c|c|c|c|c|}
\hline $\begin{array}{l}\text { Paramet } \\
\text { er }\end{array}$ & Estimate & $\begin{array}{l}\text { Approx. } \\
\text { Standard } \\
\text { Error }\end{array}$ & $\begin{array}{l}\text { Lower } \\
\text { Confidence } \\
\text { Limit }\end{array}$ & $\begin{array}{l}\text { Upper } \\
\text { Confidence } \\
\text { Limit }\end{array}$ \\
\hline $\mathrm{a}$ & 0.002091 & 0.000311 & 0.001543 & 0.002821 \\
\hline $\mathrm{v}$ & 1.342 & 0.0602 & 1.221 & 1.464 \\
\hline b & 0.01942 & 0.00149 & 0.01631 & 0.02233 \\
\hline
\end{tabular}


Correlation of Estimates

\begin{tabular}{l|lll} 
& $\mathrm{a}$ & $\mathrm{v}$ & $\mathrm{b}$ \\
\hline $\mathrm{a}$ & 1.0000 & -0.9914 & 0.1717 \\
$\mathrm{v}$ & -0.9914 & 1.0000 & -0.0597 \\
$\mathrm{~b}$ & 0.1717 & -0.0597 & 1.0000
\end{tabular}

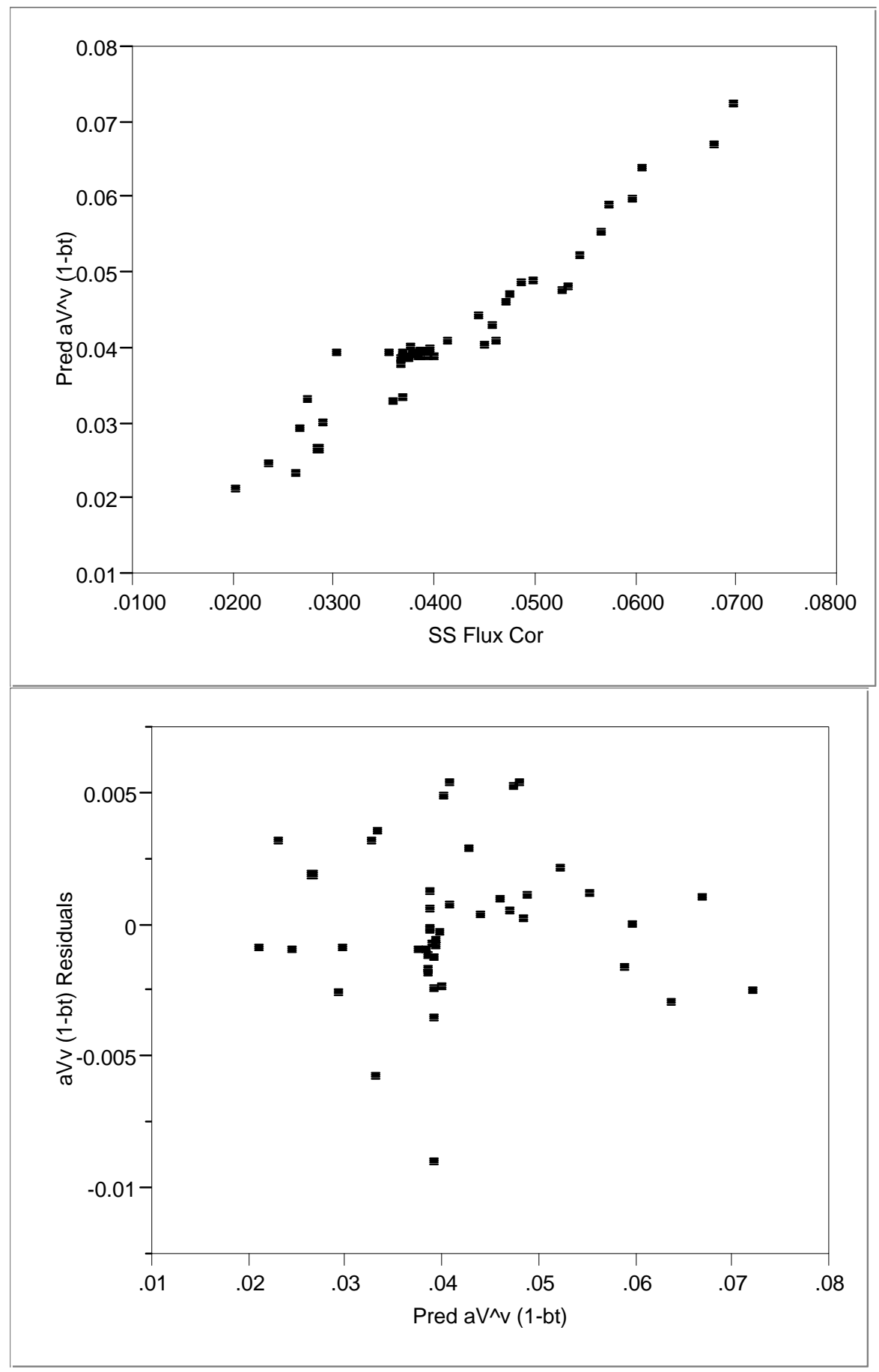


WSRC-TR-2002-00108, Rev. 0

SRT-RPP-2002-00041, Rev. 0

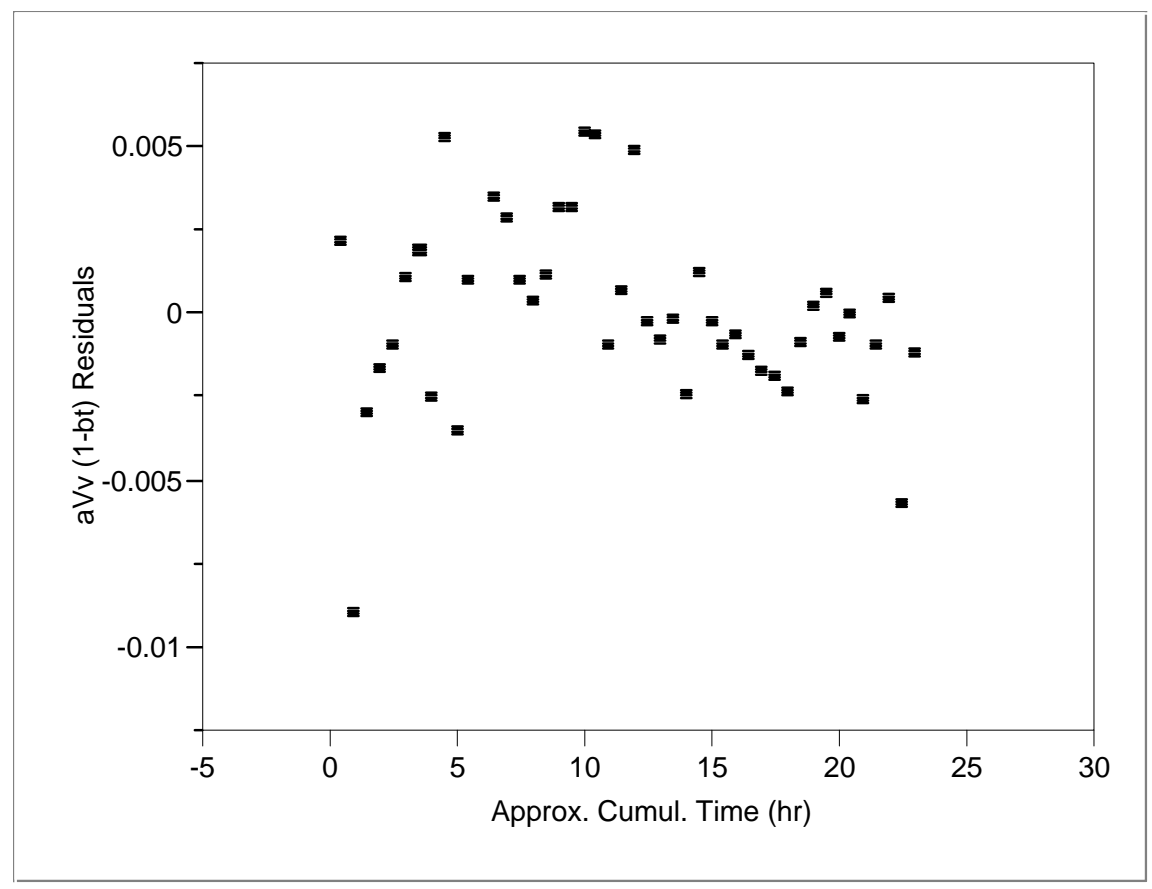

Page 81 of 82 


\subsection{References}

1 Test Specification for Evaluating Effect of Tri-Butyl Phosphate and Normal Paraffin Hydrocarbon in Simulated Low-Activity Waste Solution on Ultrafiltration and Ion Exchange Systems, TSP-W375-00-00036, Rev. 1, Washington Group International, RPPWTP, Richland, Washington, June 14, 2001.

2 LAW Evaporation: Antifoam / Defoamer Testing for Low Activity Waste Solution, TSP-W375-00-00035, Rev. 0, CH2M HILL Hanford Group, Inc., Richland, Washington, December 15, 2000.

3 Procedure for the Operation of the Cold Ultrafilter, IWT-OP-140, Rev. 0, Westinghouse Savannah River Co., Aiken, SC, November 2001.

R. E. Eibling and C. A. Nash, Hanford Waste Simulants Created to Support the Research and Development on the River Protection Project - Waste Treatment Plant, SRT-RPP2000-00017, Rev. 0 (WSRC-TR-2000-00338, Rev. 0), Westinghouse Savannah River Co., Aiken, SC, February 2001.

C. A. Nash, S. W. Rosencrance, W. R. Wilmarth, Entrained Solids, Strontium-Transuranic Precipitation, and Crossflow Filtration of AN102 Small C, SRT-RPP-2000-00003, Rev. 0 (WSRC-TR-2000-00341, Rev. 0), Westinghouse Savannah River Co., Aiken, SC, August, 2000.

E. Slaathaug, et. al, Configuration of the Ultrafiltration System, 24590-PTF-RPT-ENG01-002, Rev. 0, RPP-WTP, Bechtel Washington Group, July 30, 2001. Permanganate Addition an Solid-Liquid Separation of SRS High Level Waste, WSRC-TR2001-00554, Rev. 0, Westinghouse Savannah River Co., Aiken, SC, November 16, 2001. Co., Aiken, SC, December, 2001.

M. J. Barnes, D. T. Hobbs, R. F. Swingle, Tributylphosphate in the In-Tank Precipitation Process Facilities, WSRC-RP-93-1162, Rev. 0, Westinghouse Savannah River Co., Aiken, SC, November 23, 1993.

JMP, Version 4.0.4 for Windows, SAS Institute, Cary, NC.

11 J. R. Zamecnik, M. A. Baich, Task Technical and Quality Assurance Plan In Support of RPP - Evaluating The Effects Of Tri-Butyl Phosphate And Normal Paraffin Hydrocarbon In Simulated Low-Activity Waste Solution On Ultrafiltration, WSRC-TR-2001-00217, Rev. 0 (SRT-RPP-2001-0053, Rev. 0), Westinghouse Savannah River Co., Aiken, SC, November 2, 2001

12 Laboratory Notebook, WSRC-NB-2001-00144, Westinghouse Savannah River Co., Aiken, SC. 